UNIVERSIDAD SANTO TOMAS

Maestría en Derecho Contractual Público y Privado

\title{
EL CONTRATO DE MUTUO PARA FINANCIAR VIVIENDA FRENTE AL PARÁGRAFO 3ํDEL ARTíCULO 42 DE LA LEY 546 DE 1.999
}

Andrés Fernando Carrillo Rivera

\author{
Director \\ Joaquín Emilio Acosta \\ Abogado especializado en Contratos
}

Bogota D.C.

2012 
Tabla de Contenido

Pág.

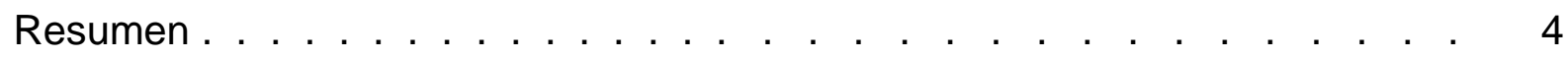

Introducción ............................ . . . 5

El Contrato de Mutuo en Colombia . . . . . . . . . . . . . . . . . . . . . . . . . . 9

Legalidad del Contrato de Mutuo para Financiar Vivienda en Colombia. . . . . 48

Regulación de intereses en materia de vivienda . . . . . . . . . . . . . 59

Recuento Histórico sobre el cambio de financiación de vivienda de UPAC a UVR. 68

Legalidad del Contrato de Mutuo para Financiar Vivienda en Estados Unidos. . . 76

La Hipoteca en Los Estados Unidos. . . . . . . . . . . . . . . . . .77

Recuento histórico sobre la crisis hipotecaria en Estados Unidos . . . . . . . . 83

Estructura del Mercado Hipotecario. . . . . . . . . . . . . . . . . . 83

Crisis del mercado hipotecario estadounidense . . . . . . . . . . . . . . . 85

Factores determinantes . . . . . . . . . . . . . . . . . . . . . . . . . 86

Fallas de regulación y supervisión . . . . . . . . . . . . . . . . . . . 101

Impacto y consecuencias . . . . . . . . . . . . . . . . . . . . . . . . . 107

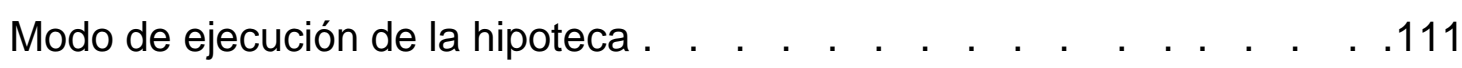

Medidas Adoptadas para la estabilización del mercado de vivienda en

Estados Unidos . . . . . . . . . . . . . . . . . . . . . . . . . . .112

Aspectos relevantes de la Crisis hipotecaria en España. . . . . . . . . . . . . 115

Análisis comparativo de la crisis hipotecaria en Colombia, EEUU y España . . . 121 
Causas que dieron origen al debate jurisprudencial en Colombia en cuanto al Parágrafo 3 del Artículo 42 de la Ley 546/99 . . . . . . . . . . . . . . . 125

Descripción y análisis jurisprudencial sobre algunas decisiones contrapuestas al interpretar el Parágrafo $3^{\circ}$ del Artículo 42 de la Ley 546 de 1.999 . . . . . . . 134 Análisis de la Sentencia de Unificación de la Corte Constitucional, SU-813 del 4 de octubre de 2007 . . . . . . . . . . . . . . . . . . . . . . . . 158 Aciertos y desaciertos de la Sentencia de Unificación SU- 813 del 4 de octubre de 2.007 de la Corte Constitucional . . . . . . . . . . . . . . . . . . . . . 169 Referencias Bibliográficas. . . . . . . . . . . . . . . . . . . . . . . 174 


\section{Resumen}

Con el presente escrito, se busca hacer una análisis completo sobre la legalidad del contrato de mutuo para financiar vivienda y los intereses máximos a cobrar en esta clase de créditos, de conformidad con la nueva legislación de vivienda (546 de 1999) y las problemáticas presentadas respecto del parágrafo 30 del artículo 42, que desde el punto de vista jurídico generaron interpretaciones contrapuestas en los diferentes estrados judiciales que conllevaron a una inseguridad jurídica para los deudores y acreedores hipotecarios. Así mismo se efectúa un análisis completo sobre la Sentencia de Unificación SU-813 de 2007 proferida por la Corte Constitucional, que resuelve la problemática anteriormente descrita, en pro de la defensa de los derechos constitucionales de los deudores, pero, que sin duda alguna deja sin protección legal a los acreedores financieros y a los terceros de buena fe.

Palabras Clave: Contrato de Mutuo - Inseguridad Jurídica - 


\section{Introducción}

Hace 37 años, mediante el Decreto 677 de mayo 2 de 1972, y con los objetivos de fomentar el sector de la construcción y estructurar un sistema de financiación de vivienda basado en el principio de valor constante, el Gobierno Nacional dio origen al sistema UPAC (Unidad de Poder Adquisitivo Constante), como reglamentación del contrato de mutuo para financiar la adquisición de vivienda, utilizando ésta modalidad especial a la figura tradicional del préstamo de dinero, lo cual para todos los efectos debía entenderse en unidades de poder adquisitivo constante.

Estos objetivos se cumplieron a cabalidad en el corto plazo, pero en el transcurso del tiempo fueron desdibujándose debido a las numerosas reformas que sufrió el sistema, las cuales condujeron a una crisis sin precedentes en la financiación de vivienda en Colombia.

Para solucionar la crisis y de acuerdo con el mandato constitucional consagrado en los derechos fundamentales de la carta magna en su artículo 51, “Derecho a Vivienda Digna” -, el Gobierno Nacional y en procura de solucionar la situación económica, social y financiera del momento, decretó el estado de emergencia económica y social a través del Decreto 2331 del 16 de noviembre de 1998, por el cual se concedieron diversos alivios a los deudores, medida que resultó insuficiente ante los créditos cuyos saldos duplicaban o triplicaban el valor de los bienes inmuebles objeto de garantía hipotecaria. Meses después, la Corte Constitucional mediante Sentencia C - 700 del 16 de septiembre de 1999, declaró la inconstitucionalidad de las normas que para entonces daban forma al sistema UPAC 
y fue promulgada la ley 546 de diciembre 23 de 1999, que dispuso la creación de un nuevo sistema para la financiación de vivienda conocido como UVR (Unidad de Valor Real).

A pesar de estos esfuerzos, la llamada "ley de vivienda" trajo consigo nuevas problemáticas, entre ellas, la interpretación del parágrafo 3 de su artículo 42 que se refiere a la suspensión y terminación de los procesos ejecutivos hipotecarios iniciados con anterioridad a 1999, por el incumplimiento del contrato de mutuo por parte de los deudores hipotecarios. (Farfán, 2002)

El hecho generador de la problemática es la coexistencia durante varios años de dos interpretaciones excluyentes entre sí; la primera de ellas, sostenida por la Corte Suprema de Justicia, consideraba que los procesos ejecutivos hipotecarios debían continuar cuando el abono concedido por el cambio del sistema UPAC a UVR no cubría la totalidad de la deuda y la segunda, sustentada por la Corte Constitucional, entendía que todos los procesos ejecutivos hipotecarios iniciados antes de entrar en vigencia la Ley 546 de 1999 debieron haber terminado por mandato legal:

La relevancia de esta problemática consiste, en que las dos interpretaciones fueron admisibles en el ámbito jurisdiccional al mismo tiempo y durante varios años, sirviendo de sustento a numerosas decisiones de jueces y tribunales, quienes en ejercicio de su autonomía se inclinaban facultativamente por la continuación o la terminación de los procesos ejecutivos hipotecarios iniciados antes de 1999. (Gracia, Echeverry \& Urdinola, 1999)

Finalmente la Corte Constitucional, con el fin de unificar la jurisprudencia y proteger en mayor grado el debido proceso en conexidad con el derecho a la vivienda digna, mediante sentencia SU - 813 de fecha 4 de octubre de 2007, 
concluyó que la interpretación que debía recibir el parágrafo 3 del artículo 42 de la ley 546 de 1999 era la de la terminación de los procesos, previa verificación del cumplimiento de ciertos requisitos por parte del deudor.

Sin embargo, la problemática que admitía dos interpretaciones sobre dicha disposición ya había provocado durante varios años múltiples efectos en procesos ejecutivos hipotecarios, de lo cual surge la inquietud en determinar hasta qué punto el pronunciamiento de la Corte Constitucional es respuesta suficiente ante la complejidad del problema.

Así las cosas, a través del presente artículo nos encargaremos de realizar una descripción legal de carácter general sobre el contrato de mutuo en Colombia y doctrinaria sobre el contrato de mutuo y el concepto de intereses en sentido general, teniendo en cuenta autores nacionales y extranjeros; un análisis sobre la legalidad del contrato de mutuo para financiar vivienda y la nueva regulación aplicable en materia de intereses en esta clase de contratos, de conformidad con lo ordenado por la nueva ley de vivienda (546 de 1.999); efectuaremos un recuento histórico sobre el cambio del sistema de financiación de vivienda de UPAC a UVR; describiremos el contrato de mutuo para financiar vivienda en Estados Unidos de América (Mortgage), con el fin de ilustrar cómo funciona este contrato en dicho país; haremos un recuento histórico de la crisis hipotecaria en Estados Unidos, resaltando los aspectos más importantes de tan difícil situación; estableceré de manera tangencial algunos aspectos relevantes de la crisis hipotecaria de España, y sólo para efectos de ilustrar al lector sobre algunas semejanzas y diferencias de la crisis hipotecaria de los 3 países (Colombia, EEUU, y España); revisaremos las causas que dieron origen al debate jurisprudencial y describiremos las principales jurisprudencias proferidas por las altas Cortes y por el tribunal de Bogotá, que dieron origen a providencias 
contrapuestas sobre la continuación o terminación de los procesos ejecutivos hipotecarios iniciados antes de 1.999; describiremos los efectos producidos por estos fallos y la solución aparente del problema mediante sentencia de unificación SU-813 del 4 de Octubre de 2.007 proferida por la Corte Constitucional, haciendo un análisis sobre las problemáticas planteadas e identificando los aciertos y desaciertos de esta decisión. 


\section{EL CONTRATO DE MUTUO EN COLOMBIA}

El Código Civil Colombiano, en sus artículos 2221 a 2235 y el Código de Comercio en sus artículos 1163 a 1169, reglamentan lo concerniente al contrato de mutuo; sin embargo hay que aclarar que respecto a la definición, características, elementos y obligaciones del contrato citado, no fueron reguladas por el Código de Comercio, puesto que el Código Civil ya lo había hecho con anterioridad, por lo tanto, cuando sea necesario, éstas normas se aplicarán de forma inmediata.

En consecuencia de lo anterior, la definición del contrato sólo se encuentra en la normatividad del Código Civil, cuando en su artículo 2221 dice lo siguiente: "El mutuo o préstamo de consumo es un contrato en que una de las partes entrega a la otra cierta cantidad de cosas fungibles con cargo de restituir otras tantas del mismo género y calidad". (p. 978)

Esta definición, que como lo dije anteriormente, sólo la contiene el Código Civil, debe aplicarse en sentido general a todos los contratos de mutuo que se celebren en el ámbito civil y comercial, luego siendo así, los contratos de mutuo para financiar vivienda celebrados entre los particulares y las entidades financieras se encuentran revestidos de legalidad. A su turno el artículo 2224 del mismo estatuto dice lo siguiente:

Si se ha prestado dinero, solo se debe la suma numérica enunciada en el contrato. Podrá darse una clase de moneda por otra, aun a pesar del mutante, siempre que las dos sumas se ajusten a la relación establecida por la ley entre las dos clases de moneda; pero el mutuante no será obligado a recibir en plata menuda o cobre, sino hasta el límite que las 
leyes especiales hayan fijado o fijaren. Lo dicho en éste artículo se entiende sin perjuicio de convención contraria". (p.980).

Teniendo en cuenta lo anterior y partiendo de la base que la doctrina es una de las fuentes formales del derecho más importantes para poder entender el contenido de las normas, veamos algunas definiciones de autores nacionales e internacionales, que a su turno en sus respectivos libros, trabajaron éste contrato.

Veamos los siguientes doctrinantes Colombianos:

El tratadista Pedro Lafont Pianeta (2002), dice:

Fue definido por el Código Civil como "un contrato en que una de las partes entrega a la otra cierta cantidad de cosas fungibles con cargo de restituir otras tantas del mismo género y calidad" art. 2221. Se caracteriza por ser típico, nominado, principal, de carácter real (por que se perfecciona con la entrega de la cosa y en este caso concreto transfiere el dominio correspondiente), unilateral (porque solo crea obligaciones a cargo de quien recibe la cosa, el mutuario, en caso de mutuo gratuito (que lo es por naturaleza) y oneroso (cuando se pacta su rendimiento), de ejecución instantánea y de libre discusión". (p.69)

El tratadista Francisco Morales (2003), argumenta:

Dentro de los contratos civiles, corrientes hay uno denominado "contrato de mutuo" que ese ordenamiento define en el artículo 2221 del Código Civil. El Código de Comercio no define el contrato de mutuo y realmente no tendría por 
qué definirlo, ya que es una figura universal que será de carácter civil cuando no conlleva el pago de réditos o intereses y que será de carácter comercial cuando en él se pacta el pago de una tasa de interés.

Sergio Rodríguez (2007), lo expresa así:

Es un contrato típico, reglamentado sin excepción en todas las legislaciones, principal, real, oneroso, en cuanto sea mercantil y unilateral pues de su celebración solo surgen obligaciones a cargo del mutuario. Se trata de un contrato real, es decir se perfecciona con la entrega de la cosa. (p.481).

El profesor Enrique Noguera (2009), señala:

Es un contrato en que una de las partes entrega a la otra cierta cantidad de cosas fungibles con cargo de restituir otras tantas del mismo género y calidad de conformidad al artículo 2221, es un contrato real, unilateral, gratuito y traslaticio de dominio. En el mutuo mercantil se regula desde el articulo1163 al 1169 y sus características son: onerosidad (artículos 884 y 1163 del Código de Comercio) consensualidad al no recaer en la promesa de contrato la expectativa del prometiente mutuante que deberá cumplir lo prometido (articulo 1169 Código de Comercio) y la restitución según el artículo 1164 que estipula que la fijación por el juez competente se hará tomando en consideración las estipulaciones del contrato, la naturaleza de la operación a que se haya destinado el préstamo y las circunstancias personales del mutuante y del mutuario. 
Por otra Jaime Arteaga (1.980) y Arteaga y Arteaga (1995), opinan:

El mutuo es una subespecie del préstamo, préstamo de consumo, cuyos caracteres son los de un contrato principal, real, gratuito u oneroso, por el que una de las partes (el mutuante) entrega a la otra (mutuario) dinero u otra cosa fungible con la condición de devolver otro tanto de la misma especie y cantidad. (p. 119).

Por otro lado, Germán Rojas González (2.001), considera:

El mutuo o préstamo de consumo es un contrato en que una de las partes entrega a la otra cierta cantidad de cosas fungibles con cargo de restituir otras tantas del mismo género y calidad. (p. 284).

El doctrinante Guillermo Ospina Fernández (2.005), expresa:

En el contrato de mutuo, el objeto específico está constituido principalmente por la tradición de una cosa fungible que le hace el mutuante al mutuario y por la obligación a cargo de este ultimo de restituir dicha cosa. (p. 35).

Para Ramón Meza Barros (1975), manifiesta:

El mutuo o préstamo de consumo es un contrato en que una de las partes entrega a la otra cierta cantidad de cosas fungibles con cargo de restituir otras tantas del mismo género y calidad. Las partes que intervienen en el contrato se denominan mutuante y mutuario. (p. 21).

A su turno el maestro Arturo Valencia Zea, dice: 
El mutuo es un contrato de enajenación, supone pues la tradición de la propiedad de cosas fungibles, por naturaleza tiende a ser oneroso, recae sobre cosas fungibles se autoriza la disposición de las cosas, la entrega que hace el mutuante o prestamista genera la posesión y dominio de la cosa mutuada. El mutuo genera la obligación de hacer tradición de otras cosas del mismo género y calidad; y por ser cosas fungibles jamás se extingue la obligación del prestatario o mutuario por imposibilidad absoluta. (p. 157).

Otro autor que habla del tema es Lisandro Peña (1998):

Dispone el artículo 2221 del Código Civil. Es pues el mutuo un contrato por medio del cual una parte, llamada mutuante, entrega a otra, mutuario, ciertas cosas fungibles, o lo que es lo mismo, consumibles, para que este pueda disfrutar de ellas, incluso consumiéndolas, quedando obligado a devolver otras tantas de igual género y calidad. Es unilateral, real, gratuito, principal y nominado. De conformidad al artículo 2222 del Código Civil este supone la tradición de la cosa, lo que de suyo comporta un acto de disposición plena.

Es un negocio de regulación paralela, normado en el Código Civil y en el Código de Comercio, el criterio para la mercantilidad lo da la presencia de un comerciante en una de las partes del contrato. La constitucionalización del derecho privado viene modificando el criterio dado por el numeral 3 del artículo 20 del Código de Comercio al decir que aunque muchos mutuos en principio serian comerciales por la presencia de un banco como prestamista, vienen con tratamiento especial, debido a que el destino del crédito es para la adquisición de vivienda y esto ha llevado a cierto tratamiento preferencial para 
los usuarios del sistema, en lo legal y en lo procesal, invocando para el efecto, el derecho fundamental de los ciudadanos a tener una vivienda digna.

Se entiende que el mutuo mercantil o préstamo de consumo, al igual que el civil es "un contrato en que una de las partes entrega a la otra cierta cantidad de cosas fungibles con cargo de restituir otras tantas del mismo género o calidad".

Mendoza y Martínez, citados por Arrubla (2009), sostienen que:

No es posible acudir a la remisión del Código Civil pues el legislador mercantil prevé otra cosa diferente, que al no estar definido el mutuo en la ley mercantil que se debe aplicar es el principio de la consensualidad que se contempla en el artículo 824 del Código de Comercio y que por lo tanto, el mutuo en materia mercantil no es un contrato real sino consensual, por ende la definición del Código Civil no es la pertinente para el caso. Habría que definirlo de forma diferente, como por ejemplo, señalado que es un contrato por el cual una parte se obliga a entregar las cosas o dineros acordados a la otra parte, para que las consuma y esta ultima a restituir otras tantas del mismo género y calidad.

Para Jaime Alberto Arrubla (2009), la tesis correcta es la revisionista porque: al tener el Código de Comercio un corte decimonónico parte de la existencia del derecho de obligaciones y contratos civiles y lo que hace la materia mercantil es introducir ingredientes que son pertinentes para las exigencias propias del comercio, pero en ningún caso pretenden ser exhaustivo u omnicomprensivo de la materia contractual; no cree que el 
principio de consensualidad sea de propiedad de la materia mercantil, por el contrario, es un principio de toda la materia contractual civil al ser un principio de raigambre liberal.

El mutuo como tal es un contrato unilateral dado que se sigue la máxima de Josserand, todo contrato real es unilateral, el único que se obliga es el mutuario a la restitución. Para los partidarios de la tesis del mutuo como contrato consensual, habría que agregar que sería bilateral, pues el mutuante se obligaría a entregar como efecto surgido de la celebración del contrato. $($ p.506 - 515)

Así mismo Guillermo Cardona (2001), considera:

También es llamado empréstito o préstamo de consumo. Es el contrato en que una de las partes entrega a la otra una cantidad de cosas fungibles, que este último está autorizado para consumir, con la condición de devolver en el tiempo convenido, igual cantidad de cosas, del mismo género y calidad. Es contrato real ya que no basta el consentimiento, pues es precisa la entrega de la cosa con intención de transferir el dominio sobre la misma y es unilateral al perfeccionarse por la entrega de lo dado en mutuo.

Alejandro Bonivento (2008), opina:

El mutuo tiene por objeto cosas fungibles ya que impone, al hacerse la entrega un acto traslaticio de dominio y que el mutuario, al usarla, las consumirá. Es diferente, eso sí que se dé el aprovechamiento esperado o querido. Basta que recaiga el negocio sobre cosas que se supone que con el uso natural y 
conveniente se destruyen. Es un contrato real al perfeccionarse mediante la entrega de la cosa prestada. Es unilateral porque perfeccionado el contrato, con la entrega surge la obligación para el receptor de devolver otras tantas del mismo género y calidad y de pagar en el efecto de haberse pactado intereses. No se desprenden en principio obligaciones para el mutuante.

Finalmente, vamos algunos doctrinantes de nacionalidad extranjera. Empecemos por revisar algo de la doctrina argentina, así:

El profesor argentino Dr. Fernando Quiroga José, define el mutuo comercial como:

El préstamo de una cosa que se puede considerar de género comercial, o esté destinada a uso comercial y cuando por lo menos el deudor es comerciante, no basta que el prestamista lo sea. La diferenciación es importante por los intereses, ya que el mutuo comercial se presume oneroso, permite al mutuario exigir la entrega del capital, además de los daños y perjuicios, y además por la competencia. (Pizarra Legal, 2009. p.8)

De igual forma Ricardo Luis Lorenezzetti (1.999), haciendo referencia a varios de los contratos dice:

El mutuo puede ser usado para un préstamo de consumo, pero su función principal es el préstamo dinerario, el leasing puede cumplir diversas finalidades: de cambio, garantía financiera, el fideicomiso financiero es un tipo 
pero pueden existir otras finalidades distintas como la garantía o el testamentario. (p. 359).

Por otro lado Lorenezzetti y concretándose al contrato de mutuo, manifiesta: En relación con el código civil en el artículo 2240, habrá mutuo o empréstito de consumo cuando una parte entregue a otra la cantidad de cosas que esta última autoriza a consumir devolviéndole en un tiempo convenido igual cantidad de cosas de la misma especie y calidad. La cosa que se entregue por el mutuante al mutuario debe ser consumible o al menos fungible, aunque no sea consumible. " El mutuo actual es preferentemente un préstamo de dinero y su configuración típica se aleja de las obligaciones restitutorias para acercarse a las de dar sumas de dinero, como bien lo trata el proyecto de 1.998. Por esta razón el referido proyecto define al contrato de mutuo (art. 1404) diciendo que es aquel por "el cual el mutuante se compromete a entregar al mutuario en propiedad una determinada cantidad de cosas fungibles, y éste se obliga a devolver igual cantidad de cosas de la misma calidad y especie", y luego dispone (art. 1411) que "Se aplican al mutuo las disposiciones relativas a las obligaciones de dar sumas de dinero o de genero, según sea el caso”. “.

La doctrina Argentina lo ha definido como: "aquel por el cual una parte (mutuante, prestamista, acreedor) transfiere en propiedad a la otra parte (mutuario, prestamista, deudor) una cantidad de cosas fungibles o consumibles y esta otra las recibe, obligándose a restituir, en el plazo 
convenido, igual cantidad de cosas de la misma especie y calidad (especie gratuita) o adicionándole acrecidos (especie onerosa)". (p. 363).

Adicionalmente el mismo autor expresa: El mutuo es una figura que admite una pluralidad de causas, ya que puede obedecer a una finalidad financiera de préstamo de dinero, o de una cantidad de cosas consumibles o fungibles para el comercio, o ser una liberalidad. Esta circunstancia ha permitido afirmar que es carente de homogeneidad y debe encontrarse un elemento tipificante que trascienda esta variedad. Ese dato no puede estar en la obligación restitutoria. Toda vez que es una mera consecuencia de la entrega, sino en el interés tanto del dar como del recibir. La entrega y la obligación restitutoria diferida en el plazo permite una relación de sustitución que no se da entre el capital dado y el recibido, sino entre el goce del capital y el precio relativo. (p. 365).

Siguiendo la línea de autores argentinos, encontramos a Jose M Gastaldi y Esteban Centenario que respecto del contrato de mutuo dice:

José M Gastaldi y Esteban Centenario (1.998):

préstamo es aquel vinculo por el cual una parte denominada prestador, entrega a otra denominada prestario, para que se sirva de ella, a titulo gratuito, una cosa no fungible que deberá ser devuelta en identidad (es el comodato o préstamo de uso) o a título gratuito u oneroso una cosa consumible o fungible, debiendo en este caso devolver una cosa de la misma 
especie y calidad, y en la misma cantidad con sus acrecidos (es el mutuo o préstamo de consumo, gratuito u oneroso) (p. 199).

El tratadista Luis Muñoz (1.960), argumenta:

Habrá mutuo o empréstito de consumo, dice el artículo 2240 del código civil cuando una parte entregue a la otra una cantidad de cosas que ésta última está autorizada a consumir, devolviéndole en el tiempo convenido, igual cantidad de cosas de la misma especie y calidad. Se ha criticado que el legislador emplea la palabra "entrega" al definir mutuo, pues la cosa pasa en propiedad, y sería preferible emplear la voz de "transferir".

Es indudable que las doctrinas del uso y goce han servido a muchos juristas para constituir su concepción del contrato de crédito, basándose en el disfrute de algo variablemente determinado, y así unos nos hablan de cosa, otros de cantidad, aquellos de incremento patrimonial, estos de capital etc. Son secuaces de tales teorías del uso y goce ilustres juristas como Brinz, Baudry - Lacantinerie y Wahl, Carnelutti, Carresi, Colagroso, Cosack, Greco, Gierke, Ihering etc. (p. 9).

De igual forma Daniel Guillermo Alioto (2002), de la misma línea Argentina expresa:

Vélez Sarfield, en el Código Civil, aludió a dos clases de préstamos que se distinguen entre sí según la categoría de objetos acerca de los cuales versan. 
Uno es el comodato o préstamo de uso de cosas que no pueden ser sustituidas entre sí, esto es, de cosas que no son fungibles y, por excepción, de cosas consumibles que se entregan "como no fungibles". Así ocurre, en este último caso, si, por ejemplo, se entrega vino en botellas de una partida abundante, no para ser bebido -conforme su destino natural de servir de alimento-, sino para ser lucido en una vitrina por cierto tiempo, o se prestan monedas de oro, no para ser gastadas o para servir de precio -cumpliendo de ese modo la función dineraria de unidad de cambio-, sino para ser exhibidas, ad pompam vel ostentationem causam (arts. 2255 y 2260, C.C.).

El otro préstamo tradicional, materia de este capítulo, es el mutuo civil y comercial, también llamado empréstito de consumo (o de cosas consumibles).

Se contrapone al comodato, ya que el mutuo es el préstamo de cosas consumibles y también fungibles que se transfieren en propiedad por un mutuante a un mutuario, quien al recibirlas queda habilitado a disponerlas hasta que se torna exigible la obligación de restituir una Cantidad igual de cosas de la misma especie y calidad al cabo de cierto tiempo (art. 2240 y 2241, C.C.). (p. 1)

Guillermo A Boorda, (2005):

Borda entiende que el mutuo comercial es consensual sobre la base del art. 559 del Código de Comercio, que dice: "Si nada se ha estipulado acerca del plano y lugar en que deba hacerse la entrega, debe verificarse luego que la reclame el mutuante, pasados diez días de la celebración del contrato y en el domicilio del deudor". Sin embargo, a poco en que se repare que la norma 
alude al "mutuante" como el destinatario de la "entrega", parece evidente concluir que se refiere a la restitución de la cosa dada por el mutuario y no a la transferencia del primero al segundo.

Borda sostiene que el mutuo es bilateral, "porque supone para el prestamista la obligación de entregar la cosa y para el mutuario la de restituirla en su momento y, eventualmente, la de pagar intereses."Pero esa doctrina conlleva dificultades insalvables:

$\left.1^{\circ}\right)$ por ser el mutuo un contrato real y no consensual, el mutuante no queda obligado a entregar la cosa; $2^{\circ}$ ) la tradición no constituye el cumplimiento del acuerdo y antes de ella no existe mutuo; $3^{\circ}$ ) la obligación de restituir no es causada por la convención, sino por la tradición de cosas fungibles o consumibles; y $4^{\circ}$ ) no es coherente contraer la obligación de restituir por el mutuario antes de recibir la cantidad de cosas fungibles o consumibles. p. 641-642.)

El tratadista Francisco Messineo (1.952), a su turno opina:

El mutuo es el contrato por el cual una parte entrega a otra una determinada cantidad de dinero o de otras cosas fungibles y este se obliga a restituir otras tantas cosas de la misma especie y calidad. Las cosas dadas en el mutuo pasan a propiedad del mutuario. (p. 323)

Vale la pena traer a colación la forma como MESSINEO, ve estas normas en su libro, ya que las trata como normas de orden público, por que aduce que estas, no son sólo las normas de Derecho público, sino, también, las de Derecho privado que 
tengan carácter imperativo. Lo contrario al orden público, es lo contrario a los principios fundamentales y a los intereses generales deducibles de las normas coactivas. (p. 1 a 3 ).

Henry, León y Jean Mazeaud (1.959), dicen:

"El mutuo es unas veces gratuito, como el comodato; y otras veces a titulo oneroso: la remuneración no transforma la operación en un arrendamiento de cosa; porque las cosas consumibles no son susceptibles de ser dadas en arrendamiento, por implicar el arrendamiento de la obligación de devolver la misma cosa arrendada. De hecho el mutuo es casi siempre a título gratuito, salvo cuando recae sobre dinero. (p. 441).

Anibal Marques Miranda (1.963), expresa:

El mutuo o préstamo de consumo es, en derecho civil, como lo es en el derecho comercial, un contrato real y unilateral que impone a uno de los contratantes llamado mutuario o préstamo, la obligación de restituir al otro mutuante o prestamista, una cantidad legal de cosas de la misma especie y cantidad de las que recibió y consumió. (p. 48)

Emiliano Mansilla Piza. (2.010), dice:

El contrato de mutuo es un contrato por medio del cual una persona llamada mutuante se obliga a transferir la propiedad de una suma de dinero o de otras cosas fungibles a otra persona llamada mutuario quien se obliga a devolver otro tanto de la misma especie y calidad. El mutuo es un contrato traslativo de dominio porque la transferencia del dinero o los bienes fungibles es el objeto 
principal de este. El mutuo puede ser gratuito u oneroso según lo convenido por las partes. (p. 10.)

Carlos Juan Zabala Rodríguez (1969), dice:

Puede ocurrir que sólo el mutuante ostente la calidad de comerciante. En ese caso y sustentado en el criterio de discriminación objetivo, el préstamo dado a personas que no son comerciantes se presume mercantil cuando el préstamo es materia de la actividad de quien lo hace, como ocurre con las entidades bancarias o financieras (art. 8 , incisos $1^{\circ}$ y $3^{\circ}$, C. Com.). (p. 7)

Ahora veamos algo de la doctrina venezolana:

El autor Venezolano Emilio Calvo Baca (1.998), sostiene:

El contrato de mutuo ó préstamo de consumo, "Es un contrato en que una de las partes entrega a la otra cierta cantidad de cosas fungibles con cargos de restituir otras tantas del mismo género y calidad" Art. 1735 del Código Civil. Es un contrato, en el cual una de las partes, llamada mutuante, entrega a la otra, denominada mutuario, cierta cantidad de cosas fungibles, para que este las haga suyas, con cargo de restituir otras tantas, del mismo género y calidad, pasado cierto tiempo. Lo fundamental de este contrato es restituir al mutuante la cosa recibida, de igual calidad y cantidad de las que recibió. Así tenemos que para el perfeccionamiento del contrato mutuo se debe precisar la entrega de la cosa mutuada. En todo caso, el legislador distingue entre cosas 
fungibles (y consumibles) que no son dinero, caso en el cual se aplicarán las normas del Código Civil, y el mutuo sobre dinero.

Por otro lado los autores Garrido \& Zago (1.998), consideran:

Habrá contrato real de mutuo o empréstito de consumo cuando una persona entregue a la otra en propiedad una cantidad de cosas consumibles o fungibles y que ésta última esta autorizada a consumir o a utilizar en la forma que estime conveniente, debiendo devolver, en el tiempo convenido igual cantidad de cosas muebles, fungibles o consumibles de la misma especie y calidad.

Veamos que piensan algunos de los autores Peruanos:

Javier Rodríguez Velarde (2002), opina que:

El Contrato de mutuo: Se le conoce como préstamo de consumo por el cual el acreedor llamado mutuante se obliga a entregar en préstamo una suma determinada de dinero o bienes consumibles denominados en su cantidad, calidad y especie a favor del mutuario, quien se obliga a devolver en un plazo convenido, otros bienes en igual cantidad, calidad y especie. (p. 88)

Fernando Tola Cires (1.997), argumenta:

"El mutuo o préstamo de consumo, es el contrato en virtud del cual, una persona transfiere a otra la propiedad de ciertas cosas que se pesan, numeran o miden, como el vino, el aceite, el trigo, la plata acuñada; de tal manera que 
el que las recibe debe devolver no las mismas cosas, sino cosas de la misma naturaleza y calidad." (P. $166-167)$.

Darío Herrera Paulsen y otro (1.999), manifiesta:

Es el préstamo de consumo que se forma sin solemnidad por la datio de una cosa fungible (datio mutui) con el acuerdo de devolverla en la misma calidad y cantidad. De modo que la mera promesa de efectuar un préstamo carece de fuerza vinculativa. Es, pues, un contrato a término y gratuito. Es de derecho estricto. (p. 177.)

Ahora veamos algo de la doctrina mexicana:

El autor mexicano Rafael Rojina Villegas (1985), expresa:

Es un contrato por el cual una persona llamada mutuante, transfiere a otra, llamada mutuario, una cantidad de dinero o de bienes fungibles que el último se obliga a restituir en bienes de la misma cantidad, calidad y especie. (p. 479)

El mexicano Jesús Saldaña Pérez (2.004), dice:

El mutuo es un contrato bilateral, consensual, por medio del cual una persona llamada mutuante se obliga a transferir a otra llamada mutuatario o mutuario la propiedad de una cantidad de dinero o de otras cosas fungibles, obligándose este ultimo a devolverle otro tanto de la misma especie y calidad. (p. 411)

Eugene Petit, (1.971) señala: 
Etimológicamente, la palabra mutuo tiene su raíz en el latín mutŭus1, Esta etimología demuestra su origen en Roma. En donde para existir un contrato de mutuo era indispensable la mutui datio. Para Eugene Pettit el mutui datio es "un traslado de propiedad, a título de préstamo, en beneficio del prestatario"

El mutuum, o préstamo de consumo, es un contrato por el cual una parte transfiere a otra la propiedad de cierta cantidad de cosas que se aprecian al peso, numero o a la medida, con obligación de restituir al cabo de cierto tiempo la misma cantidad de cosas de la misma cantidad de cosas de la misma especie y calidad." (p. 377).

Ricardo Treviño García (1.994), señala

El mutuo es un contrato principal ya que para él "Un contrato es principal cuando existe por sí mismo, es decir, tiene existencia propia, no depende de ningún otro contrato." (p. 69.)

Ricardo Treviño García (1.995), Expresa:

El objeto en el contrato de mutuo lo constituye la cantidad de dinero o los bienes fungibles que el mutuante se obliga a transmitir al mutuatario. (p. 113).

El Código Civil para el Distrito Federal de México, SISTA S.A. de C.V. en su Art. 2384, dice: 
El mutuo es un contrato por el cual el mutuante se obliga a transferir la propiedad de una suma de dinero o de otras cosas fungibles al mutuatario, quien se obliga a devolver otro tanto de la misma especie y calidad."

Finalmente, revisemos algunos de los mejores autores Españoles en derecho civil:

El Español Diez-Picazo (1.986), por su parte, aporta la siguiente definición: considera contrato aquel "acuerdo de voluntades de dos o más personas (duorum vel plurium consensus) dirigido a crear obligaciones entre ellas (ad constituendum obligationem)".

Se le conoce como Préstamo de consumo, por el cual el acreedor llamado Mutuante, se obliga a entregar en préstamo una suma determinada de dinero o bienes consumibles denominados en su cantidad, calidad y especie a favor del Mutuatario, quien se obliga a devolver en un plazo convenido, otros bienes en igual cantidad, calidad y especie.

En el contrato siempre habrá consentimiento común de dos o varias partes; a su vez, se obtendrá como resultado una obligación con fuerza de ley. Originariamente no existía una relación clara entre contrato y acuerdo de voluntades, a pesar de asociarse. Cuando se hablaba del primero se hacía referencia a una obligación de carácter solemne, es decir, el contrato y, por ende, las obligaciones no nacían del acuerdo de voluntades sino del cumplimiento de ciertos ritos o formalidades establecidos previamente; por tanto, el contrato (con-tractus) existía sólo en la medida en que se cumpliera 
el ritual, sin importar que las partes hubiesen o no manifestado antes su voluntad.

Así mismo, Carlos Ghersi (1995), señala:

El mutuo es de carácter real, es decir que se perfecciona con la tradición de la cosa, sin embargo el codificador ha regulado la promesa de mutuo como contrato en sí mismo y lo ha hecho de dos formas, como supuesto oneroso y gratuito. (p.441)

María Sánchez (1992), expresa:

Es la entrega de dinero u otra cosa fungible, con condición de devolver otro tanto de la misma especie y calidad en cuyo caso conserva simplemente el nombre de préstamo, puede ser gratuito o con pacto de pagar intereses. El préstamo como operación de las que puede realizar la banca se recoge en el artículo 175, numeral 7 del Código de Comercio si bien con las características reguladas por el Código Civil no aparece que se efectué en la actual práctica de las entidades de crédito, aunque el autor Pedro González manifieste que dicho contrato es "jurídicamente el instrumento más frecuente para la financiación actual de las empresas". (p.161).

Rodrigo Bercovitz (2009), expresa:

Tal y como viene configurado el contrato de préstamo en el Código Civilapartándose en este punto de la reglamentación contenida en el proyecto de 1851, que configuraba el contrato con carácter consensual- parece tratarse de 
un contrato de naturaleza real, de tal modo que se perfecciona en virtud de la entrega de la cosa objeto del préstamo y no del mero consentimiento. Igualmente se ha predicado por doctrina y jurisprudencia del carácter real del tradicional préstamo mercantil. De este modo, de la mera promesa de prestar por parte del prestamista, no nacería en principio, obligación alguna, como tampoco surge la obligación de devolución para el prestatario, hasta que el bien fungible objeto del contrato no es entregado a este ultimo. En este momento la propiedad del bien se transmite al prestatario el cual debe restituir otro tanto de la misma especie y calidad. Es por ello por lo que tradicionalmente también se considera el contrato de préstamo, tanto civil como mercantil un contrato unilateral. En realidad, el prestamista no asume obligaciones. La entrega del objeto del préstamo es constitutiva del préstamo mismo y no cumplimiento de una obligación previa por su parte. El único obligado por el contrato de préstamo es el prestatario: debe devolver la cantidad prestada y en su caso los intereses estipulados.

Ramón Marti y de Eixala (1.938), opina:

El contrato de mutuo "resulta de la entrega de una cosa fungible, transfiriendo el dominio de ella, con la condición de devolver otro tanto de la misma especie el que la recibe en esta forma". (p.187).

Biondo Biondi (1.953), argumenta:

Desde un punto de vista lingüístico, el nombre del préstamo de consumo, llamado mutuo, entraña una contracción que indica el fenómeno jurídico 
implicado en el contrato: derivado del vocablo latino mutuum, señala que lo "mío" se hace "tuyo" (p. 109)

Para terminar éste capítulo, nos parece importante resaltar lo que consagra el Código Civil Frances:

Código Civil Frances (1.804), Artículo 1892:

"El préstamo de consumo es un contrato por el que una de las partes entrega a otra una cantidad determinada de cosas fungibles, estando obligado este a devolver otro tanto de la misma especie y calidad."

Finalmente, vale la pena resaltar algunas de las definiciones más importantes respecto de éste contrato y que se encuentran en algunos diccionarios jurídicos, al igual que una definición que para el efecto a conceptualizado la Superintendencia Bancaria, hoy Superintendencia Financiera, así:

El diccionario de la lengua española (2001), consagra:

Contrato real en el que se da dinero, granos, aceite $u$ otra cosa fungible, de suerte que la haga suya quien la recibe, obligándose a restituir la misma cantidad de igual genero en día señalado. (p. 657).

El diccionario jurídico mexicano (1.998), expresa

El mutuo es un contrato por el cual el mutuante se obliga a transferir la propiedad de una suma de dinero o de otras cosas fungibles al mutuario, quien se obliga a devolver otro tanto de la misma especie y calidad. (p. 2169). 
La Superintendencia Bancaria de Colombia a través de su concepto $\mathrm{N}$. 1999015883-2 del 4 de mayo de 1999, preceptuó:

El contrato de mutuo o préstamo de consumo en materia comercial implica, en los casos en que el mismo versa sobre dinero, el reconocimiento de intereses de plazo y moratorios de las sumas de dinero entregadas a dicho título; son intereses de plazo o remuneratorios aquellos "causados por un crédito de capital durante el plazo que se le otorga al deudor para pagarlo, al paso que los moratorios corresponden a la indemnización de perjuicios que debe satisfacer el deudor cuando ha incurrido en mora de pagar la cantidad debida, según definición de la Corte Suprema de Justicia".

De lo anterior se puede concluir, que si bien es cierto, existe diversidad de autores nacionales y extranjeros que trabajan el contrato de mutuo en general, no es menos cierto, que la mayoría de ellos coinciden perfectamente en la interpretación lógica de la norma en cuanto a las características principales del contrato de mutuo que lo hacen diferente a los demás, pues, la mayoría converge en que es un contrato que se caracteriza por ser real, unilateral, y que recae sobre una cosa fungible 0 consumible, independientemente de ser un contrato de mutuo civil o comercial respectivamente. En el mismo sentido, tenemos que decir, que una vez revisados los artículos contentivos de la definición general del contrato de mutuo o préstamo de consumo en las diferentes legislaciones, se puede concluir que estamos hablando prácticamente de la misma norma, la cual regula nuestro ordenamiento colombiano. 
Ahora bien, me parece importante resaltar concretamente algunos criterios, que respeto, pero no comparto académicamente-, de algunos tratadistas Colombianos y de los cuales me gustaría compartir con ustedes a manera de opinión personal y con un tinte, como lo dije anteriormente, netamente académico, ya que estoy seguro que será en pro de quienes nos gusta el debate con altura. Para el efecto, y teniendo en cuenta que un buen grupo de ellos coincide en poco o mucho, con lo que no comparto, trataré los temas en sentido general respecto de lo que se dice, mas no de quien lo dijo, omitiendo traer a colación el nombre del autor que lo argumentó.

Algunos dijeron que como el Código de Comercio, no define el contrato de mutuo comercial por ser una figura universal civil que no genera réditos y que al momento en que se pacte lo anterior será un contrato de mutuo comercial. Al respecto tengo que decir que esto no es cierto. No es viable jurídicamente hablar de la mutación del contrato de mutuo civil a un contrato de mutuo mercantill por el simple hecho de pactarse intereses dentro de éste contrato. De ser así, entonces, a un contrato de mutuo civil que se le aplica legislación civil, por el simple hecho de pactar intereses, tendría que aplicar ahora la legislación del Código de Comercio. Decir esto, me parece que estaría desconociendo los elementos de los contratos (Escenciales, Naturales y Accidentales), que precisamente, en virtud del elemento natural de los mismos, - gratuidad en el civil y onerosidad en el mercantil-, es que puedo convertir a través de un elemento accidental, - pacto de intereses -, el mutuo civil naturalmente gratuito, en contrato de mutuo civil oneroso; al igual, que en virtud del mismo principio, yo puedo convertir a través de un elemento accidental, - pacto 
de no cobro de intereses -, un contrato de mutuo comercial naturalmente oneroso, en un contrato de mutuo mercantil gratuito, eso sí, manteniendo en cada uno de ellos la regulación de su esencia, es decir, el mutuo civil legislación civil y en el mutuo mercantil, legislación mercantil. Lo anterior se verifica en los artículos (2224, 2229, 2230,2232, 2233, 2234 del C.C. y 1163 del C.Co).

Otros dicen, que el criterio de la mercantilidad del contrato de mutuo, lo da la presencia de un comerciante en una de las partes del contrato. Decir esto, es cambiar el criterio objetivo del acto de comercio regulado en nuestra legislación comercial, donde precisamente en el artículo 20 ibidem, se establecen cuales actos se reputan comerciales, - algunos generados por comerciantes, otros no-, y es precisamente el ordinal $3^{0}$ de éste artículo que faculta a cualquier persona, comerciante o no a realizar contratos de mutuo comercial. Ahora bien, que se pueda interpretar, que de los tres (3) casos que trae éste ordinal el último lo pueda interpretar que lo puede realizar un comerciante, es diferente a tomar la posición absoluta, que debe ser un comerciante quien puede realizar dicho contrato. (art. 20 No 3. Del C.Co).

Adicionalmente a lo anterior, algunos de los autores confunden el concepto de fungibilidad con consumibilidad, diciendo que es lo mismo. Si bien es cierto el Código Civil Colombiano en su artículo 2221 habla de " El contrato de mutuo o préstamo de consumo", no es menos cierto que lo hizo diferenciando los dos conceptos, y no como algunos tratadistas lo ven, tratando las dos figuras como si fueran sinónimos. Una cosa es cosa fungible y otra, cosa consumible. Las cosas fungibles se pueden 
sustituir y no desaparecen del mundo jurídico por su uso (el dinero), y entonces se llamará "contrato de mutuo", mientras, que las consumibles desaparecen con el uso (el vino que se encuentra dentro de una botella), y entonces se llamará Contrato de préstamo de consumo. Tanto así que pueden existir o catalogarse no fungible a algo consumible, como cuando entrego la botella de vino para exhibirla en algún evento social y entonces se llamará contrato de préstamo de uso, la obligación del prestatario se traduce en entregar la misma botella que fue entregada en préstamo.

Veamos, a manera ilustrativa lo que algunos autores de lo que dicen al respecto:

Marco Gerardo Monroy Cabra (2003), tratadista Colombiano, Expresa:

Cosas fungibles, son aquellas cosas en que todo individuo de la especie equivale perfectamente a otro de la misma, y pueden, por tanto, sustituirse. Cosas no fungibles, son aquellas que poseen un grado suficiente de individualización, hacen imposible la equivalencia o sustitución entre sí. Consumible. Cosas Consumibles, aquellas cuya existencia terminan con el primer uso (Ejemplo: Comestibles). No consumible, son lo contario (Ejemplo: Moneda). Se pueden sustituir. (p. 334 y 335.)

Juan Iglesias (2002), tratadista español, argumenta:

Son fungibles, las cosas que se pueden sustituir por otras de la misma categoría. 
Son las cosas, digámoslo de otro modo, que no se toman en consideración como individualizadas, sino en cantidad. Es una categoría genérica. Son consumibles aquellas cuyo destino lleva aparejada la destrucción o la transformación. No fungibles Son las cosas apreciadas por sus características individuales. Es una categoría individualizada. No consumible Son las susceptibles de un uso repetido. (p. 144)

Fernando López de Zabalia. (2004), dice:

En ese sentido, una situación es juzgar que una cosa fungible puede transformarse en no fungible por autoridad de las partes, y otra contraria es considerar un inmueble genéricamente y no en su individualidad, haciéndolo aparecer como si fuera fungible.

Por otro lado y bien importante, es revisar la teoría de los que dicen que el contrato de mutuo mercantil es consensual, porque al no definir el código de comercio que es un contrato de mutuo mercantil, debe aplicarse el artículo 824 del código de comercio que habla del principio de consensualidad para todos los actos mercantiles. Decir esto, es desconocer la unilateralidad del contrato de mutuo, característica que se genera a partir de la realidad del mismo, es decir, que el contrato se perfecciona con la entrega de la cosa, - o sea, solo surge obligación para el mutuario -, para convertirlo en un contrato bilateral que se perfecciona con el acuerdo de voluntades y entonces surgen obligaciones para ambas partes, el mutuante se obligaría a entregar el dinero y el mutuario a restituirlo. 
Finalmente, si todo lo anterior lo aplicamos a el estudio del contrato de mutuo en materia de vivienda, y como lo diré más adelante cuando hablemos de éste contrato especialmente, la discusión se torna más pacífica, pues, si tenemos en cuenta que los contratos de mutuo en materia de vivienda lo hacen los bancos, pues ese contrato de mutuo es netamente mercantil, ya que se encuentra inmerso en la tercera situación que comprende el ordinal $3^{\circ}$ y el primer evento del ordinal 7 del artículo 20 del código de comercio. Vale la pena aclarar que si bien es cierto, se cataloga éste contrato como contrato mercantil, no es menos cierto, que cuando se trata de vivienda existe una regulación especial dada por la ley 546 de 1999 y por ende sus intereses son regulados de forma especial a través de las resoluciones que para ello expide la junta directiva del Banco de la República. Por otro lado, éste contrato de mutuo es de cosas fungibles (dinero para adquisición de vivienda), es real, - se perfecciona con la entrega-, entendiéndose que por el tráfico mercantil, muchas veces la entrega es simbólica ya que los bancos no le entregan el dinero a sus mutuarios en efectivo y personalmente, si no, que se le consigna a la cuenta del deudor o a quien ellos autoricen consignar, respectivamente.

Ahora, si bien es cierto, que partimos de la base que en nuestra legislación colombiana sólo existe una definición para identificar el contrato de mutuo civil y mercantil, la cual se encuentra establecida en el artículo 2221 del Código Civil, pues, el Código de Comercio no trae una definición especial para esta clase de contratos, no es menos cierto, que existen características de cada uno de ellos que lo diferencian palmariamente y es en lo que respecta al tema de intereses. El contrato de mutuo civil es naturalmente gratuito, es decir, que la obligación del mutuario se 
limita a devolver dentro del plazo, en el préstamo de dinero, la suma de capital entregada sin interés alguno, siempre y cuando las partes no hubieren pactado intereses; mientras que en el mutuo mercantil lo caracteriza la onerosidad del contrato, es decir, que así las partes no hubieren pactado intereses, el mutuario dentro del plazo deberá devolver la suma adeudada con los rendimientos o intereses respectivos.

Teniendo en cuenta la importancia del tema de intereses en los contratos de mutuo, revisemos algunos conceptos o definiciones que de esto tienen algunos autores nacionales e internacionales:

Veamos los siguientes doctrinantes Colombianos:

Henry Alberto Becerra (2010), expresa:

1.- El interés es el costo del dinero en una unidad determinada de tiempo. También puede entenderse como el fruto civil de un capital exigible (art. 717 del C.C.), o como el valor de la indemnización de los perjuicios por mora, si la obligación es de pagar una cantidad de dinero. (art. 1617 del C.C.).

2.- Si se tiene en cuenta su origen, el interés puede ser legal, si nace por disposición de la ley, o convencional, si surge de la estipulación de las partes.

3.- Dependiendo del periodo en que se cause, puede ser de plazo (para algunos denominado remuneratorio o corriente ), entre la fecha de surgimiento de la obligación y la fecha de vencimiento de ésta, y de mora, si se causa 
entre la fecha en que se hizo exigible y la fecha de pago efectivo y total de la obligación. (el artículo 65 de la ley 45 de 1990 define en materia comercial el interés de mora, como toda suma que se cobre al deudor como sanción por el simple retardo o incumplimiento del plazo de una obligación dineraria, cualquiera que sea su denominación).

Jorge Camacho Cubides (1999), a su turno dice:

a) "De acuerdo a su origen, los intereses pueden ser: corrientes, legales o convencionales"; b) "según la época del crédito a la cual se refieren, son: remuneratorios o de plazo y los moratorios o vencidos"; c) "según la capacidad de producir nuevos intereses, de su reinversión o capitalización, se pueden distinguir los intereses simples o compuestos"; d) según su cálculo o medida, los intereses pueden ser nominales, efectivos o reales", y e) "según la época de su pago, los intereses pueden ser vencidos o anticipados". En lo que respecta a este trabajo sólo se hará alusión a la forma de constitución, es decir: convencionales, corrientes o legales; y de acuerdo a si corresponden a título de lucro o indemnización. (p. 124).

Sergio Rodríguez Azuero (2000), sostiene:

la tasa de interés puede concebirse respecto a dos momentos en la vida del contrato, o mejor, del cumplimiento de las obligaciones derivadas. Una es la que se cobra durante la vigencia del contrato que corresponde al precio del dinero o, si se quiere, a la remuneración por el sacrificio que hace el acreedor 
al privarse durante un cierto tiempo de la disponibilidad de los recursos ( $p$. 484).

Néstor Humberto Martínez (2003), expresa:

Algunos doctrinantes nacionales más próximos a las realidades económicas definen el interés remuneratorio como el precio del dinero percibido durante la vigencia del contrato. Otros lo conciben como el costo de oportunidad del capital o recurso económico. (p. 488.)

Emilio Robledo Uribe. (1959), opina:

"Intereses convencionales. Como su nombre lo indica, son los intereses fijados de mutuo acuerdo por las partes. Estas no tienen libertad absoluta para determinarlos. La ley señala un máximum. Sólo se puede estipular el interés corriente más una mitad del mismo. Así lo determina el artículo 2231 del código civil. Si bien este artículo se encuentra en el capítulo relativo al mutuo, soy de parecer, dados los términos amplios en que está concebido, que se extiende a toda clase de estipulaciones y contratos. ( $p$ 128).

Guillermo Ospina Fernández (1994), a su turno dice:

Respecto al cobro de intereses moratorios la preceptiva legal es diferente, por el contrario y por lo que respecta a los intereses moratorios, existe una autorización legal y general para su cobro, tratándose de obligaciones mercantiles de carácter dinerario y en caso de mora y a partir de ella (Art 45 de la Ley 45 de 1990). (p. 297). 
Adicionalmente a lo anterior, en el año 2001, el mismo autor en su obra " Régimen general de las obligaciones" manifiesta:

El dinero, aunque esté representado por moneda fiduciaria, o sea, respaldada en todo o en parte por la fe del Estado, es también en si mimo un bien patrimonial susceptible de constituir objeto de transacciones comerciales, ya a cambio de otros bienes, ya al facilitárselo alguien a otro para obtener como contraprestación el pago de un rédito o interés.

Teniendo en cuenta la preindicada naturaleza del dinero, su función en el intercambio comercial y la facilidad de su inversión, el legislador reconoce, en general, su rentabilidad o aptitud para producir intereses que así constituyen los frutos civiles del dinero (art. 717); y, además, establece al respecto una serie de regulaciones que miran a varios fines, tales como el de sancionar el incumplimiento de las obligaciones de dinero, el de prefijar el monto de los intereses a falta de estipulación convencional, y de otro lado, siguiendo una tradición legislativa inspirada en el propósito de combatir la usura, a mantener las estipulaciones al respecto dentro de los limites que se consideran razonables y justos. (p. 275)

José Alejandro Bonivento (1995), manifiesta:

El solo hecho de entregarse una cosa en préstamo de consumo implica para el mutuario la obligación de cubrir intereses, que a falta de estipulación será el legal, que en materia mercantil corresponde al bancario corriente. (p. 558). 
Arturo Valencia Zea (1986), Expresa:

Denominase interés, la suma de dinero que produce un capital durante un periodo de tiempo (días, meses, años). Todo derecho patrimonial debe producir determinadas ventajas o frutos, y las ventajas o rendimiento de una suma de dinero se denomina interés.

Los intereses son una prestación accesoria a la deuda pecuniaria principal, de donde se deducen las siguientes consecuencias:

A. Sin un crédito principal no existen intereses. Así, los precios de la renta vitalicia no son intereses, por falta de obligación principal sobre qué apoyarse. B. Los intereses siguen la suerte de la prestación principal. Si prescribe la deuda pecuniaria, prescriben con ella los intereses.(...)

C. Pero una vez constituida, la obligación de intereses tiene sustantividad propia y puede sobrevivir a la obligación principal; aun después del pago de la deuda pecuniaria, pueden ser demandados los intereses, siempre que, dadas las circunstancias, el recibo sin reserva no signifique renuncia. (p. 354 y 355 ).

Jaime Azula Camacho (1999), a su vez, haciendo un tratamiento especial sobre el cobro excesivo de intereses frente a la reducción de los mismos, manifiesta:

Tiene por objeto que el juez reduzca el monto de los intereses que debe cancelar el deudor a los corrientes vigentes al momento de celebrarse la convención, cuando los reclamados por el acreedor y ordenados pagar en el mandamiento ejecutivo están afectados de lesión enorme, conforme lo previsto por el articulo 2231 del código civil. 
Requisitos Para que se configure la lesión es indispensable, en primer lugar, que se trate de obligaciones de carácter civil; en segundo, que los intereses estén pactados en el titulo ejecutivo, porque, a falta de estipulación, rigen los legales, que son del $6 \%$ anual, de acuerdo con lo dispuesto por el articulo 2232 del Código Civil; y, en tercer lugar, que el interés pactado exceda de una mitad del interés corriente al tiempo de la convención.

Frente al tema de la reducción y pérdida de intereses el autor dice:

En las operaciones reguladas por el Código de Comercio la situación en la actualidad es semejante a la prevista para el campo civil, por cuanto el articulo 884 de ese ordenamiento fue modificado por el articulo 72 de la ley 45 de 1990, en el sentido de cambiar la pérdida por la reducción de los interés a los limites permitidos por la norma y con referencia al corriente, pero le agrega una sanción, consistente en que el acreedor debe cancelarle al deudor una cantidad igual.

Requisitos Los presupuestos para que obre la reducción de intereses consisten, en primer lugar, que se trate de una obligación mercantil o comercial; en segundo, que los intereses, sea por concepto del plazo o la mora, estén expresamente pactados en el titulo ejecutivo, y, en tercer lugar, que esos intereses excedan el limite señalado en la ley o por la autoridad monetaria, pues es factible que en unos eventos sea aquella y en otros esta, por existir norma especial al respecto. (p. 89).

Hernán Fabio López Blanco (2004), arguye: 
Si se trata de ejecutar una obligación de dar sumas de dinero, el art. 491 prescribe que puede solicitarse no solo el pago de la cantidad liquida, entendiendo por tal la "cifra numérica precisa o que sea liquidable por simple operación aritmética, sin estar sujeta a deducciones indeterminadas", sino también los intereses desde que se hicieron exigibles hasta que el pago se efectúe. En esta modalidad que constituye, la más usual de las ejecuciones, es posible demandar no solo el capital adeudado, sino también los perjuicios moratorios que, en tratándose de dinero, se denomina intereses, que se solicitarán de acuerdo con lo pactado en el titulo ejecutivo, si allí aparece estipulación expresa al respecto y están dentro de los márgenes legales, o a falta de esta, de acuerdo con lo que la ley prevé y la índole de la obligación, civil o comercial, de diferente alcance en lo que a su monto respecta. (p. 440).

José Ignacio Narváez García. (2002), manifiesta:

El interés es un elemento de la naturaleza del mutuo mercantil. La finalidad de percibirlo es el móvil que impulsa al mutuante a contratar. El interés es el precio que se paga por el uso del capital que es objeto del mutuo, aunque el provecho o remuneración que recibe el mutuante no sea siempre en dinero o estipulado a una tasa precisa. Si el mutuario se obliga a restituir una suma mayor que la recibida del mutuante, la diferencia representa el interés, el cual eventualmente puede ser pagado en su totalidad o parcialmente en especie. (...) En síntesis, en el mutuo mercantil las partes pueden pactar o no 
intereses; pero si se guarda silencio sobre el particular, la ley ordena que el mutuario pague al mutuante intereses legales comerciales. (p. 162).

Carlos Andrés Delvasto (2008), manifiesta:

En las operaciones crediticias normalmente existen dos agentes: uno de estos se caracteriza por ser el propietario del recurso económico; el otro agente es un tercero (con respecto a la cosa) que se caracteriza por valorar más ese recurso económico. Al primero se le denomina mutuante o prestamista $(A)$, al segundo mutuario o prestatario $(\mathrm{B})$. El mecanismo de precio es la manera en que se determina quién valora más el recurso económico en el mercado.

Dicho en otras palabras, $(\mathrm{A})$ le prestará a $(\mathrm{B})$ el recurso económico solo en la medida en que (B) se encuentre dispuesto a pagar más por usar el recurso de lo que $(A)$ estaría dispuesto a pagar para retenerlo. Este precio se conoce como la tasa de interés.

La tasa de interés bancaria corriente es la base o punto de referencia en orden a determinar el límite a la tasa de interés que rige todo el mercado crediticio en Colombia. (p. 102).

Ahora, veamos algo de la doctrina Peruana:

Elvira Martínez Coco (1.997), dice:

Luis DIEZ-PICAZO citado por Elvira MARTÍNEZ COCO precisa que: "En términos económicos se denomina interés al precio o remuneración que una 
persona ha de pagar por la utilización o disfrute de bienes de capital de pertenencia ajena. Como quiera que los bienes de capital constituyan factores de producción, su utilización o disfrute proporciona un beneficio por el cual debe pagarse un precio. En términos jurídicos, sin embargo, el concepto de interés es un concepto más abierto. Jurídicamente, son intereses las cantidades de dinero que deben ser pagadas por la utilización y el disfrute de un capital consistente también en dinero. (p. 137).

Salvador Vásquez Olivera (2002), señala:

Son "Cantidades de dinero que deben ser pagadas por la utilización y el disfrute de un capital consistente también en dinero." (p. 334).

Gastón Fernández Cruz. (1991), argumenta:

Sostiene que la noción jurídica de interés parte de una concepción económica de capital. Constituye un rendimiento por la aplicación debida o indebida de un capital y, en función del tiempo de aplicación, dicho rédito estará constituido por bienes de la misma naturaleza que los debidos por la prestación. (p. 178).

Carmen del Pilar Robles de Arévalo (1999), opina:

En la legislación civil se puede encontrar tanto el interés convencional como el legal. En la legislación financiera también se puede encontrar ambos tipos de interés, pero con la peculiaridad que en economías como la peruana, en la que las tasas de interés aplicables para adeudos dentro del sistema financiero 
se encuentran liberalizadas (y como consecuencia de ello el precio del interés se fija por la oferta y la demanda), "no se da una ‘convención' en estricto entre un sujeto deudor y un sujeto acreedor, sino que el precio se rige por la oferta y la demanda, que engloba a un grupo de sujetos ofertantes de dinero y a un grupo de sujetos demandantes de dinero." (p. 2).

Miremos que piensan algunos de los doctrinantes Españoles:

Luis Diez Picazo (1996), indica:

los intereses son las cantidades de dinero que deben ser pagadas por la utilización y el disfrute de un capital consistente también en dinero. (p. 282).

Enneccerus Lehman (1944), argumenta:

Los intereses son una retribución por la privación de utilizar el capital y a la vez una prima por el riesgo que acarrea la concesión del crédito. (p. 233).

Andreas Von Thur. (1934), opina:

Económicamente considerados, los intereses representan la renta del capital de que el acreedor se priva; jurídicamente pueden considerarse como frutos civiles del crédito. (p. 9).

Veamos algo de la doctrina Argentina:

Carlos Gilberto Villegas y Mario Schujman (1990), precisa:

El interés es compensatorio (según el artículo 1242 del Código civil) cuando constituye la contraprestación por el uso del dinero o de cualquier otro bien. 
“La denominación de 'compensatorios' es histórica pero quizá no exprese con claridad la función de esta categoría de intereses, que hemos conceptualizado como la ganancia del capital. En este sentido, la denominación más correcta sería 'intereses lucrativos', porque compensar es igualar en opuesto sentido el efecto de una cosa con el de otra, y también dar alguna cosa o hacer un beneficio en resarcimiento del daño, perjuicio o disgusto que se ha causado. (...) Esta categoría de intereses tiene por función otorgar un beneficio, un lucro al capital invertido o transferido." (p. 100).

J. J. Llambías (2004), opina:

La evolución del proceso económico hizo posible concebir que el pago de los intereses compensatorios del mutuo no siempre comportara una injusticia, en la medida en que se hicieron frecuentes las ocasiones de concreción de inversiones productivas, francamente difundidas desde que el préstamo del ahorro fue canalizado en buena parte a través de los bancos. De ese modo se crearon las condiciones que llevaron a presumir que la privación del ahorro del mutuante es fuente de una desventaja que se compensa con el rédito pagado por el mutuario en virtud de la ventaja correlativa que le reporta el incremento de su aptitud productiva de bienes y servicios hasta la restitución del principal. Bien entendida que tanto la ventaja como la desventaja se calculan según el probable lucro dejado de cobrar por el mutuante en razón de la imposibilidad de invertir la cantidad prestada por la privación sufrida, que es mesurable en un mercado financiero determinado y se supone mayor en materia mercantil. (p. 206.) 
Finalmente, tengamos un referente de un autor mexicano:

Govinden Lincoyan Portus (1.999), dice que el interés:

Es el alquiler o rédito que se conviene pagar por un dinero tomado en préstamo. Por el dinero tomado en rédito en préstamo es necesario pagar un precio. Este precio se expresa por una suma a pagar por cada unidad de dinero prestada en una unidad de tiempo convencionalmente estipulada. ( $p$. 4).

No sobra traer a colación y para cerrar este capítulo, lo que dice el diccionario para contadores cuando manifiesta:

Interés: Cargo de servicio por el empleo de dinero o de capital que el usuario paga a intervalos convenidos y que se expresa comúnmente como porcentaje del capital ganado no pagado. Rendimiento de cualquier inversión de capital. 


\section{LEGALIDAD DEL CONTRATO DE MUTUO PARA FINANCIAR VIVIENDA EN COLOMBIA}

En el capítulo anterior hablamos de la definición del contrato de mutuo en general, que como lo dije anteriormente, sólo la contiene el Código Civil y debe aplicarse en sentido general a todos los contratos de mutuo que se celebren en el ámbito civil y comercial, luego siendo así, los contratos de mutuo para financiar vivienda celebrados entre los particulares y las entidades financieras se encuentran revestidos de legalidad. A su turno el artículo 2224 del mismo estatuto dice lo siguiente:

Si se ha prestado dinero, solo se debe la suma numérica enunciada en el contrato. Podrá darse una clase de moneda por otra, aun a pesar del mutante, siempre que las dos sumas se ajusten a la relación establecida por la ley entre las dos clases de moneda; pero el mutuante no será obligado a recibir en plata menuda o cobre, sino hasta el límite que las leyes especiales hayan fijado o fijaren. Lo dicho en 'este artículo se entiende sin perjuicio de convención contraria. (p.980)

En este sentido y para efectos de nuestro tema a tratar, el contenido de la norma dio la posibilidad, - aplicando la interpretación extensiva de la misma -, que el contrato de mutuo para financiación de vivienda fuera posible pactarlo en moneda colombiana o en Unidades de Cuenta, - que para el caso concreto es el UPAC -, siempre y cuando las sumas se ajusten a la relación establecida por la ley al momento del pago. 
A partir de la nueva ley de vivienda consagrada en la ley 546 de 1.999, en su artículo 1 parágrafo, se establece lo siguiente:

Sin perjuicio de lo establecido en la presente ley, las entidades del sector solidario, las asociaciones mutualistas de ahorro y crédito, las cooperativas financieras, los fondos de empleados, el Fondo Nacional de Ahorro y cualesquiera otra entidad diferente de los establecimientos de crédito, podrán otorgar créditos de vivienda denominados en moneda legal colombiana o en Unidades de Valor Real UVR, con las características y condiciones que aprueben sus respectivos órganos de dirección, siempre que los sistemas de amortización no contemplen capitalización de intereses, ni se impongan sanciones por prepagos totales o parciales. (Ley 546 de 1999, (p.7, 8) (negrillas fuera de texto).

Lo anterior quiere decir, que una vez extinguido el UPAC como antiguo sistema de financiación de vivienda, a partir de la vigencia de la nueva ley, sólo es posible que los contratos de mutuo para financiar vivienda que se celebren con las instituciones mencionadas en el parágrafo 1 del Artículo 1 de la ley 546 de 1.999, sean pactados exclusivamente en pesos o en UVR.

De igual forma la legislación de vivienda contenida en la ley mencionada, por primera vez, a través de su artículo 20, inciso primero, le ordena a la Superintendencia Bancaria, hoy Superintendencia Financiera de Colombia, establecer las condiciones uniformes que deberá contener como mínimo los documentos contentivos de las condiciones del crédito, (Pagaré y Escritura pública 
de hipoteca), que en sana lógica son los documentos donde se materializa el contrato de mutuo para financiar vivienda.

Artículo 20: HOMOGENEIDAD CONTRACTUAL: La Superintendencia Bancaria establecerá condiciones uniformes para los documentos contentivos de las condiciones del crédito y sus garantías, mediante los cuales se formalicen las operaciones activas de financiación de vivienda individual a largo plazo. ... (p. 21)

Teniendo en cuenta, que la actual ley de vivienda fue proferida por el Congreso de la República como ley marco y de acuerdo al mandato legal establecido en el artículo 20 ibídem, donde se le ordena a la Superintendencia Bancaria reglamentar las condiciones uniformes que deben contener todos los contratos de mutuo para el financiamiento de vivienda, se emite la circular externa No 85 de 2.000, la cual fue modificada por la circular externa No 2 de 2.001 (actualmente vigente), la cual desarrolló los artículos 20 y 21 de la ley 546 de 1.999. En tal sentido la circular en sus numerales 2, 2.1, y 2.1.1, 2.2., trata el tema de de la Uniformidad de los documentos contentivos del crédito de vivienda individual a largo plazo de la siguiente forma:

2. UNIFORMIDAD DE LOS DOCUMENTOS CONTENTIVOS DEL CRÉDITO DE VIVIENDA INDIVIDUAL A LARGO PLAZO.

2.1. Contrato de mutuo o pagarés.

2.1.1. Condiciones uniformes: 
Todo contrato de mutuo o pagaré debe contener como mínimo las siguientes estipulaciones:

a. Identificación de las partes intervinientes en el negocio.

b. El monto del crédito expresado en UVR y su equivalencia en pesos, o el monto adeudado en pesos, cuando se trate de obligaciones denominadas en moneda legal.

c. La destinación del crédito. Debe indicarse que el crédito se destinará a la adquisición de vivienda nueva o usada o a la construcción de vivienda individual. Para efectos de que el crédito quede clasificado como crédito hipotecario de vivienda, el destino sólo puede ser la compra de vivienda, entendiéndose por tal, la financiación que se otorga a personas naturales que buscan una solución de vivienda para su núcleo familiar y/o al mejoramiento de la misma, tratándose de vivienda de interés social.

d. Plazo de la obligación. Podrá pactarse entre cinco (5) años como mínimo y treinta (30) como máximo, según elección y capacidad de pago verificada del deudor, indicando la forma de pago en número de cuotas mensuales y la fecha de la primera cuota.

e. La tasa de interés remuneratoria del crédito. Cuando se trate de créditos pactados en UVR la tasa de interés remuneratoria de los créditos de vivienda individual a largo plazo y de los créditos para financiar proyectos de construcción de vivienda no podrán exceder los topes máximos establecidos por la Junta Directiva del Banco de la República, y se aplicará sobre la UVR. Cuando se trate de créditos pactados en moneda legal, la tasa nominal fija de los mismos no podrá exceder la suma de la variación de la UVR de los últimos 12 meses vigente al perfeccionamiento del 
contrato, más el tope máximo establecido por la Junta Directiva del Banco de la República para la tasa remuneratoria.

f. El sistema de amortización aplicable a la deuda que se contrae, previa y expresamente aprobado por la Superintendencia Bancaria.

g. Los seguros necesarios para garantizar el cubrimiento de los riesgos de incendio y terremoto a los que está expuesto el inmueble financiado, así como los seguros definidos en los manuales de crédito de las instituciones financieras, particularmente el seguro de vida deudores. En todo caso se deberá indicar la libertad que tiene el deudor de asegurar el bien con la compañía de seguros que escoja y la cobertura y demás condiciones exigidas en cada caso por el establecimiento de crédito.

h. Impuestos y gastos a cargo del deudor. Deberá indicarse clara y detalladamente aquellos que se causen al momento del perfeccionamiento del contrato. Para el efecto, debe tenerse en cuenta que de acuerdo con el numeral 54 del artículo 530 del Estatuto Tributario, tal como fue adicionado por el artículo 46 de la Ley 633 de 2000, los pagarés que instrumenten cartera hipotecaria se encuentran exentos del impuesto de timbre.

i. Las causales para dar aplicación a la cláusula aceleratoria del plazo del contrato. Esto en el entendido de que el incumplimiento en el pago de la obligación no dará lugar a que la totalidad de la misma se considere de plazo vencido, hasta tanto no se presente la correspondiente demanda judicial.

j. En adición a las anteriores, y si el deudor lo solicita, deberá estipularse la constitución del patrimonio de familia inembargable, de conformidad con las normas que rigen la materia, por el valor total del inmueble y siempre 
que el crédito haya sido otorgado como mínimo por el cincuenta por ciento (50\%) de dicho valor.

El patrimonio de familia así constituido perderá su vigencia cuando el saldo de la obligación hipotecaria represente menos del veinte por ciento $(20 \%)$ del valor de la unidad habitacional. “

2.2. Contrato de Hipoteca. Además de las condiciones definidas en los ordinales $\mathrm{a}, \mathrm{b}, \mathrm{d}, \mathrm{g}, \mathrm{h}$, i y j del sub numeral 2.1.1 de este instructivo, los documentos constitutivos de la hipotecar deberán contener como mínimo:

a. Identificación plena del bien hipotecado. Esto es la descripción del inmueble, sus linderos, la dirección y cédula catastral que le corresponde así como mínimo el número de matrícula inmobiliaria asignado.

b. La causa que da origen a la hipoteca.

c. El monto por el cual se otorga la hipoteca. Se debe indicar la cantidad de unidades de valor real, UVR, y su equivalencia en pesos, e el monto adeudado cuando se trate de obligaciones denominadas e moneda legal.

d. Garantía con hipoteca de primer grado. El contrato accesorio de hipoteca se debe constituir sobre el bien inmueble financiado y se debe indicar expresamente que tal hipoteca se contrata para garantizar el préstamo otorgado por la entidad vigilada.

e. La cesión de la Hipoteca. Las condiciones para efectuar la cesión de la hipoteca deberán atender lo ordenado en el inciso segundo del artículo 24 de la ley 546 de 1999. (Superintendencia Bancaria, 2001.) 
Ahora, si bien es cierto, que para celebrar un contrato de mutuo para financiar vivienda hoy en día se requiere de la participación lógica y coherente de un sistema normativo idóneo y sistemático que regulan éste contrato, como lo son: Las normas generales que se encuentran en el Código Civil y Código de Comercio, y las normas especiales que regulan la financiación de vivienda, o sea la ley 546 de 1.999; no es menos cierto, que la aplicación de las anteriores no son de carácter absoluto, pues, el estado a través de sus instituciones a hecho intervención directa a este sistema de financiación, con el fin de proteger y garantizar al ciudadano Colombiano el principio constitucional de acceso a una vivienda digna, - y que de hecho trataremos a profundidad más adelante -, y donde a través de la Corte constitucional se limitó el principio privado de la autonomía de la voluntad para ésta clase de contratos. Es por ello que en Sentencia de Tutela No 943/05 del 8 de Septiembre de 2005, proferida por nuestra Corte Constitucional, se establece la Naturaleza del contrato de mutuo con garantía hipotecaria para la adquisición de vivienda y la procedencia de la intervención estatal en el negocio jurídico que realizan los actores del contrato.

En consecuencia de lo anterior y en vista de la importancia que reviste dicho fallo vemos con suma importancia compartir con nuestros lectores el extracto de dicha providencia donde la corte Constitucional expresa:

El contrato de mutuo o préstamo de consumo, es un negocio jurídico de carácter real y privado, regulado en forma genérica por el ordenamiento civil colombiano y de manera específica por el comercial, como aquel convenio en que una de las partes entrega a otra cierta cantidad de cosas fungibles con 
cargo de restituir otras tantas del mismo género y calidad. Se señalan en tales codificaciones las características del contrato relativas a las formas de perfeccionamiento, a los tratamientos específicos según la clase de la cosa objeto de convenio, a los términos para restitución, a los intereses y responsabilidades por vicios ocultos de la cosa. En consecuencia, y a voces del artículo 1602 del Código Civil, todo contrato de mutuo celebrado que atienda a esas previsiones, es ley entre las partes y no puede ser invalidado sino por su consentimiento mutuo o por causas legales.

Estas causas legales incluyen las circunstancias en que la intervención estatal en la estipulación de las condiciones del mutuo, se justifica por la necesidad de regular y garantizar derechos constitucionales y la prestación de un servicio público a su cargo, como es el bancario. En estos eventos ya no serán absolutamente libres los términos de la contratación de los mutuantes, sino que estará dirigida por disposiciones imperativas que consultan el interés público. Es el caso de los contratos de mutuo con garantía hipotecaria, cuyos créditos son otorgados por las entidades financieras para la adquisición y conservación de vivienda, éstos han sido regulados por el Estado en cumplimiento de su deber constitucional de fijar las condiciones necesarias para hacer efectivo el derecho a la vivienda digna y de promover los planes de vivienda de interés social, los sistemas adecuados de financiación a largo plazo y las formas asociativas de ejecución de estos programas de vivienda. 
Sobre este tipo de negocio jurídico, la Corte Constitucional en los siguientes términos ha expresado que restringen la autonomía de la voluntad:

"El otorgamiento y la aceptación de créditos por las entidades financieras para la adquisición y conservación de vivienda, mediante contratos de mutuo con garantía hipotecaria, no se rigen de manera absoluta por el principio de la autonomía de la voluntad sin limitación alguna, sino que ellos son contratos que han de obedecer a la intervención del Estado, esto es, que son contratos de los que la doctrina denomina "dirigidos", en los que, en aras del interés público y las finalidades sociales, se restringe la autonomía de la voluntad."

En este contexto, normas que ordinariamente rigen el contrato de mutuo entre particulares no son aplicables tratándose de aquellos créditos hipotecarios de vivienda a largo plazo, por encontrase intervenidos por el Estado a fin de facilitar a las personas el acceso a la vivienda digna, y por lo tanto, para éstos, no rige de manera absoluta el principio de la autonomía de la voluntad.

Lo anterior no significa, que una vez pactadas las condiciones con sujeción a esas disposiciones legales correspondientes, las partes puedan apartarse de ellas, pues para que puedan ser modificados los términos de un contrato se requiere el consenso de los contratantes, sin perjuicio de la intervención estatal para imponer una específica variación de ciertos 
aspectos del contrato, como puede ejemplarizarse con el conocido caso de las negociaciones que otrora legalmente se efectuaron en UPACS.

Ahora bien, las diferencias o discrepancias que surjan con relación a este tipo de contratación, que no puedan ser solucionadas de mutuo acuerdo, tendrán que ser resueltas por los jueces ordinarios y no por el juez de tutela, dada la subsidiariedad que la misma Constitución le imprimió a esta acción, salvo que se utilice como mecanismo transitorio para evitar un perjuicio irremediable.

Como pudimos ver, es claro que la corte coloca límites a la autonomía de la voluntad y eso se va a ver reflejado cuando tratemos el capítulo inmediatamente siguiente y es en lo que respecta a la regulación de intereses, pues el estado en su función interventora, creó tasas de interés especiales para los contratos de mutuo en materia de vivienda y de esta forma y como garantizar de alguna forma el acceso a la vivienda digna de los ciudadanos.

Para finalizar éste tema, quisiera hacer un comentario de la sentencia anteriormente descrita, en lo que respecta al siguiente párrafo:

“Lo anterior no significa, que una vez pactadas las condiciones con sujeción a esas disposiciones legales correspondientes, las partes puedan apartarse de ellas, pues para que puedan ser modificados los términos de un contrato se requiere el consenso de los contratantes, sin perjuicio de la intervención estatal para imponer una específica variación de ciertos aspectos del 
contrato, como puede ejemplarizarse con el conocido caso de las negociaciones que otrora legalmente se efectuaron en UPACS.".

Es obvio que los contratos son ley para las partes y que no podrán ser modificados sino por mutuo acuerdo entre ellas, sin embargo, existe la posibilidad de modificarse cuando el estado interventor por políticas económicas así lo deciden, por ejemplo: Cuando en la mayoría de los contratos de mutuo que fueron suscritos en UPAC y atados a una corrección monetaria del IPC, fue por voluntad del estado, tomar la decisión de cambiar ésta última al DTF, generando incremento en las obligaciones hipotecarias y crisis en los pagos de los usuarios en el sector financiero. De igual manera, como cuando en vigencia de la ley 546 de 1.999, ésta ordenó que todo lo que dijera UPAC, se debía entender de ahora en adelante como UVR. Si nos damos cuenta, ninguna de las partes cambió las condiciones iniciales del contrato, sino que precisamente en virtud del intervencionismo estatal que ha existido desde tiempo atrás, es el estado a través de sus instituciones reguladoras las que pueden variar las condiciones o algunas de las condiciones de éste contrato.

Regulación de intereses en materia de vivienda

Hablar del contrato de mutuo para financiar vivienda, sin remitirnos al tema de los intereses, es tratar de forma incompleta el contrato mencionado, pues a pesar de que en principio se piense que por el simple hecho configurarse un acto de comercio como lo es la suscripción de un pagaré emitido por una entidad financiera, (Articulo 20 No 6 y 7 del C.C.) se deberían cobrar los intereses convencionales comerciales 0 
en ausencia del convenio, los regulados en el artículo 884 del Código de Comercio; la realidad es otra, pues la normatividad aplicable para esta clase de negocios, es decir, para los contratos de mutuo para financiamiento de vivienda, se encuentran sometidos a la normatividad especial consagrada por la ley 546 de 1.999 y por las regulaciones especiales proferidas por la Junta Directiva del Banco de la República en materia de intereses, como veremos a continuación.

La ley 546 de 1.999 distingue dos clases de vivienda, es decir, la vivienda individual normal y la vivienda de interés social, por ello en su artículo 17. Condiciones de los créditos de vivienda individual, para créditos de vivienda normal general, en su numeral 2 dice:

Tener una tasa de interés remuneratoria, calculada sobre la UVR, que se cobraría en forma vencida y no podrá capitalizarse. Dicha tasa de interés sería fija durante toda la vigencia del crédito, a menos que las partes acuerden una reducción de la misma y deberán expresarse única y exclusivamente en términos de tasa anual efectiva.

En sentencia C-955 de 2.000, la corte declaró exequible el numeral anteriormente descrito, pero en el entendido de que se aplique bajo las siguientes condiciones, según lo manifestado por la corte así:

El numeral 2 sólo es EXCEQUIBLE en el entendido de que la tasa de interés remuneratoria a que se refiere no incluirá el valor de la inflación, sería siempre inferior a la menor tasa real que se esté cobrando en las demás operaciones crediticias en la actividad financiera, según certificación de la superintendencia bancaria, y su máximo sería determinado por la Junta Directiva del Banco de la República, conforme a lo resuelto por la Corte 
Constitucional, en sentencias C-481 del 7 de Julio de 1.999 y C-208 del 1 de marzo de 2.000. (Resolución Externa, 14 de 2000)

De igual forma, la ley 546 de 1.999 en su artículo 28, Obligaciones de los establecimientos de crédito de destinar recursos a la financiación de vivienda de interés social, PARÁGRAFO dice: "Para toda la vivienda de interés social la tasa de interés remuneratoria no podrá exceder de once (11) puntos durante el ano siguiente a la vigencia de la presente ley". En sentencia C-955 de 2.000 la corte declaró exequible el parágrafo anteriormente descrito, y añadió:

Sería la Junta Directiva del Banco de la República, de conformidad con sus facultades constitucionales y legales, la autoridad competente para los efectos de fijar las condiciones de financiación de créditos de vivienda de interés social, los cuales deben ser las más adecuadas y favorables, a fin de que consulten la capacidad de pago de los deudores y protejan su patrimonio familiar, también bajo el entendido de que la tasa real de interés remuneratorio no comprenderá la inflación y será inferior a la vigente para los demás créditos de vivienda. (Resolución Externa, 20 de 2000)

Por otra parte en la Resolución 8 de 2006 se expone lo siguiente:

En la ley 31 de 1.992 literal e) del artículo 16, atribuye a la Junta Directiva del Banco de la República la función de señalar las tasas máximas de interés remuneratorio que los establecimientos de crédito pueden cobrar o pagar en sus operaciones activas y pasivas, sin inducir tasas reales negativas, de igual forma en la Sentencia de Constitucionalidad C-208 de 2.000 la corte 
constitucional, se reitera la autonomía técnica del Banco de la República para la fijación administrativa de la tasa de interés, la cual debe hacerse dentro del marco fijado por la ley. Dicho marco comprende lo previsto en el artículo 16 de la ley 31 de 1.992, el cual dispone que el banco de la república le corresponde estudiar y adoptar las medidas monetarias, crediticias y cambiarias para regular la circulación monetaria, la liquidez del mercado financiero el normal funcionamiento del sistema de pagos. (Subrayado fuera de texto).

De lo anterior se concluye que en materia de créditos destinados a la financiación de vivienda individual a largo plazo (vivienda normal) o créditos destinados a la financiación de vivienda de interés social, los intereses máximos a cobrar por concepto de intereses remuneratorios o de plazo deben ser fijados por la Junta Directiva del Banco de la República.

Así las cosas, éste órgano procedió en principio a emitir la resolución 14 de septiembre 3 del año 2.000, que consagraba los límites máximos en materia de intereses para financiar vivienda individual a largo plazo y para proyectos de construcción de vivienda, fijando como tope 13.1 puntos porcentuales nominales anuales, pagaderos mes vencido adicionales a la UVR, cuando los créditos fueron pactados en UVR, o 13.1 puntos porcentuales nominales anuales, pagaderos mes vencido, adicionados con la variación de la UVR de los últimos 12 meses vigente al perfeccionamiento del contrato, cuando los créditos fueron pactados en PESOS.

De la misma manera, se expidió la resolución 20 de Diciembre 22 del año 2.000 para los créditos de vivienda de interés social, fijando como tope 11 puntos 
porcentuales adicionales a la UVR, cuando los créditos fueron pactados en UVR, o 11 puntos porcentuales, adicionados con la variación de la UVR de los últimos 12 meses vigente al perfeccionamiento del contrato, cuando los créditos fue pactado en PESOS.

Finalmente, la Junta Directiva del Banco de la República profirió la Resolución Externa No 8 de Agosto 18 de 2.006, la cual recoge las dos resoluciones anteriores, modifica una de ellas e incluye la regulación de los topes de operaciones de leasing habitacional la cual había sido regulada mediante resolución externa No 3 del año 2.005, expresando:

RESOLUCIÓN EXTERNA No 8 DE 2006 (Agosto 18) Por la cual se señala la tasa máxima de interés remuneratorio de los créditos destinados a la financiación de vivienda individual a largo plazo, de proyectos de construcción de vivienda, y de vivienda de interés social, así como de los contratos y operaciones de leasing habitacional destinados a vivienda familiar.

En consecuencia, esta resolución deroga la Resolución 14 del año 2.000 en cuanto al tope máximo de intereses remuneratorios a cobrar para los créditos de financiación de vivienda a largo plazo y proyectos de financiación de vivienda, imponiendo como tope máximo para esta clase de créditos 12.7 puntos porcentuales efectivos anuales, adicionales a la UVR, cuando los créditos fueron pactados en UVR, o 12.7 puntos porcentuales efectivos anuales, adicionados con la variación de la UVR de los últimos 12 meses vigente al perfeccionamiento del contrato, cuando los créditos fueron pactados en PESOS. 
En cuanto a los créditos de vivienda de interés social, esta resolución mantiene el tope máximo a pactar como intereses remuneratorios y su forma de aplicación, e incluye los topes máximos de las operaciones de leasing habitacional que son los mismos asignados para vivienda normal y vivienda de interés social, es decir, que cuando se efectúe una operación de leasing habitacional de vivienda individual de largo plazo sería del 12.7 puntos, o del 11.00 puntos cuando se trate de un leasing habitacional de una vivienda de interés social, manteniendo de esta forma los parámetros ya enunciados y dependiendo, si es en UVR o en PESOS respectivamente.

Ahora bien, si estamos hablando de intereses en materia del contrato de mutuo para financiar vivienda, es más que obligatorio terminar este capitulo, abordando el estudio de los topes máximos a cobrar en materia de intereses moratorios que se generan cuando los deudores dejan de cancelar dentro del plazo convenido sus respectivas cuotas hipotecarias.

Es importante aclarar, así como lo hice cuando abordamos los intereses remuneratorios, que a pesar de que estos contratos de mutuo son contratos mercantiles especiales, - mercantiles por que se encuadran en el articulo 20 No 6 y 7 del Código de Comercio, y especiales por que tienen una reglamentación especial.no se les aplica las normas mercantiles que regulan el concepto de intereses, sino las especiales consagradas en la ley de vivienda.

En ese orden de ideas, atinadamente la ley 546 de 1999 en su artículo 19, al contrario de lo que ocurrió con los intereses remuneratorios, - reguló el tope máximo a cobrar en materia de intereses moratorios indicando lo siguiente: 
Articulo 19. Intereses de mora. En los préstamos de vivienda a largo plazo de que trata la presente ley no se presumen los intereses de mora. Sin embargo, cuando se pacten, se entenderán que no podrán exceder una y media veces el interés remuneratorio pactado y solamente podrán cobrarse sobre las cuotas vencidas. En consecuencia, los créditos de vivienda no podrán contener cláusulas aceleratorias que consideren de plazo vencido la totalidad de la obligación hasta tanto no se presente la correspondiente demanda judicial. El interés moratorio incluye el remuneratorio. (López, 2001; p.63)

Entonces, podemos decir que el artículo 19 impone un tope a cobrar como intereses moratorios que corresponde como máximo al 1.5 del interés remuneratorio pactado, y que como lo dijimos iniciando éste capítulo, éste se deberá pactar respetando las tasas máximas señaladas por la Junta Directiva del Banco de la República.

Seguidamente, es necesario manifestar que los intereses moratorios sólo se pueden cobrar sobre las cuotas en mora, es decir, sobre las cuotas atrasadas, pero nunca podrá cobrarse intereses moratorios sobre saldos insolutos, es decir, sobre las cuotas futuras, salvo que el acreedor hipotecario presente la demanda judicial, haciendo efectiva la cláusula aceleratoria del pagaré, lo cual lo facultará a pedir intereses moratorios sobre el saldo de la obligación desde la presentación de la demanda.

En conclusión, en vigencia del crédito y sin mediar acción judicial, sólo se pueden cobrar intereses moratorios sobre las cuotas en mora o cuotas atrasadas, y mediando acción judicial o proceso ejecutivo hipotecario, se pueden cobrar intereses 
moratorios sobre las cuotas atrasadas e intereses moratorios sobre el saldo insoluto teniendo como fecha de mora el día de la presentación de la demanda.

De lo anterior, se concluye que hoy todas las entidades financieras que financian vivienda deben respetar y acatar la normatividad vigente, incluyendo en todos los contratos de mutuo y en los contratos de hipoteca los requisitos anteriormente mencionados. Vale la pena aclarar que el sistema de financiación de vivienda en Colombia, debe contener estos dos títulos, es decir la suscripción del pagaré que es el documento donde se plasma el contrato de mutuo, - respetando las condiciones de fondo y de forma ya descritas, así como la regulación especial para el pacto de los intereses respetando los topes máximos a cobrar, - y el otorgamiento de la garantía hipotecaria sobre el bien objeto de adquisición, construcción o mejoramiento; que se materializa con el otorgamiento de la Escritura Pública de Hipoteca.

Adicionalmente, el segundo inciso del mismo artículo, impone obligaciones adicionales y complementarias, - de las contenidas en los contratos de mutuo -, a los establecimientos de crédito con el propósito de garantizarle a los deudores hipotecarios el buen comportamiento del crédito y para ello deberán aquellos suministrarle a éstos, información entendible y completa, que mínimo deberá contener la proyección de los intereses que se están cobrando y los que se cobraran a futuro.

Lo anterior con el fin de que los deudores acudan a las entidades financiadoras de vivienda durante los dos primeros meses de cada año calendario a solicitar la reestructuración de su obligación, cuando así lo requieran. 
Ahora veamos como surge esta unidad de cuenta y como fue adoptada para el sistema de financiación de vivienda. 


\section{RECUENTO HISTORICO SOBRE EL CAMBIO DE FINANCIACION DE VIVIENDA DE UPAC A UVR}

Hace más de tres décadas, es decir en 1.972, el gobierno, como parte de su plan de desarrollo y con el propósito de canalizar recursos hacia el sector de la construcción, mediante el Decreto 677 de mayo 2 de 1972, determinó que los recursos se obtendrían con el fomento del ahorro sobre el principio de un valor constante del dinero, dando origen al sistema UPAC (Unidad de Poder Adquisitivo Constante), unidad que en adelante incluía una nueva reglamentación y de carácter especial para el contrato de préstamo de dinero o contrato de mutuo. (Guía práctica, 2002)

En consecuencia de lo anterior el Gobierno mediante decreto 678 del mismo año, autorizó la creación de las corporaciones privadas de ahorro y vivienda con el objeto de estimular el ahorro de los particulares y canalizarlo hacia la construcción, de forma tal que tanto los ahorros como los préstamos mantuviesen su valor, de acuerdo con las variaciones del poder adquisitivo de la moneda, sistema que cumplió los objetivos para lo cual fue creado, pero que en el transcurso del tiempo, se fueron desdibujando, debido a las numerosas reformas que sufrió el sistema de financiación de vivienda a largo plazo.

En el título II. De los derechos, las garantías y los deberes. Capítulo 1. De los derechos fundamentales. Artículo 51 de la Constitución Política de Colombia de 1.991, se establece: "Todos los Colombianos tienen derecho a vivienda digna. El estado fijará las condiciones necesarias para hacer efectivo este derecho y promoverá planes de vivienda de interés social, sistemas adecuados de financiación 
a largo plazo y formas asociativas de ejecución de estos programas de vivienda" ( $p$. 24,25)

En virtud de este mandato constitucional, y previa acción de inconstitucionalidad presentada por un ciudadano Colombiano, el estado a través de la Corte Constitucional declara la inconstitucionalidad del sistema de financiación de vivienda en UPAC (Unidad de Poder Adquisitivo Constante) que se encontraba inmerso en los contratos de mutuo para financiar vivienda, y en su reemplazo, ordena al Congreso de la República crear una ley marco que estableciera los parámetros generales del sistema de financiación de vivienda, bajo los criterios enunciados en la Constitución y el cual debía contener todo contrato de mutuo de esta clase.

Para el efecto el Congreso promulgó la ley 546 del 23 de Diciembre de 1.999 que dispuso la creación de un nuevo sistema para la financiación de vivienda conocido como UVR (Unidad de Valor Real). A continuación, procederé a ilustrar de mejor manera lo anteriormente planteado.

U.P.A.C.: Sigla de la Unidad de Poder Adquisitivo Constante, primera unidad de cuenta del sistema para financiamiento de vivienda en Colombia basado en el principio de valor constante del dinero, creada mediante Decreto 677 de mayo 2 de 1972 expedido por el Presidente de la República para reactivar el sector de la construcción como quiera que ningún factor de la economía veía rentable este tipo de inversión a largo plazo. Casi de inmediato, el Decreto 678 del mismo año, dispone la creación de las Corporaciones de Ahorro y Vivienda (CAVs); de manera que ambos Decretos conforman el primer sistema para financiamiento de vivienda basado en el principio de valor constante. 
En consecuencia, los contratos de mutuo para financiamiento de vivienda no utilizaban la moneda de curso legal como unidad de cuenta, sino utilizaban UPACs, de modo que el usuario no adeudaba determinada cantidad de pesos sino de UPACs, y por ello, el Decreto 1229 de 1972 asignó a la Junta de Ahorro y Vivienda el reajuste de la unidad de cuenta, calculando su valor para cada día del mes siguiente conforme a la variación del IPC (Índice de Precios al Consumidor) en el periodo trimestral inmediatamente anterior. Posteriormente el Decreto 1110 de 1976 suprime la Junta de Ahorro y Vivienda y encomienda sus funciones a la Junta Monetaria del Banco de la República.

Fueron múltiples las modificaciones al sistema, tanto en el periodo considerado para tomar el promedio de variación del I.P.C. (Decretos 969 de 1973, 269 bis de 1974 y 58 de 1976) como en el límite de aumento anual para la unidad de cuenta (Decretos 1278 de 1974, 1685 de 1975, 58 de 1976, 272 de 1986 y 50 de 1988, entre otros).

En virtud del Decreto 1131 de 1984 el cálculo de la UPAC deja de estar ligado exclusivamente al IPC y entra en consideración para determinar su valor, el rendimiento promedio efectivo ponderado de los certificados de depósito a término fijo del mes inmediatamente anterior.

La tasa DTF toma preponderancia por encima del IPC para el cálculo de la UPAC hasta que la Resolución Externa número 6 de 1993 liga su cálculo casi exclusivamente $(90 \%)$ a la DTF en lugar del IPC, y aunque dicho porcentaje después fue reducido por la Resolución externa No. 26 de 1994 y la Circular Externa No. 18 de 1995, la introducción de tasas de interés en el cálculo de la UPAC conllevó un 
aumento exacerbado en el valor de la unidad de cuenta, conduciendo a una crisis sin precedentes en la financiación de vivienda en Colombia.

Esta situación llevó al Gobierno Nacional a implantar mecanismos de solución, y para el efecto decretó el estado de emergencia económica y social a través del Decreto 2331 del 16 de Noviembre de 1.998, por el cual se concedieron diversos alivios a los deudores de vivienda, los cuales fueron otorgados a través del Fondo de Garantías de Instituciones Financieras, FOGAFIN, medida que resultó insuficiente ante los créditos cuyos saldos duplicaban o triplicaban el valor de los bienes objeto de garantía.

Si bien es cierto, que con la entrada en vigencia de la Constitución Política de Colombia de 1.991, se elevó a la categoría de derecho constitucional " La vivienda digna ", ratificando la preocupación del estado por las condiciones en que viven sus ciudadanos, lo cual lo faculta para intervenir en la actividad económica con miras a la realización de éste derecho a través de planes para acceder a viviendas de interés social y sistemas de crédito, no es menos cierto, que las medidas tomadas para enfrentar la crisis del sistema generada por el excesivo aumento de las cuotas hipotecarias de los créditos de los deudores, fueron insuficientes, de manera que agravaron el problema, en vez de solucionarlo, haciendo cada vez más urgente el reclamo por una solución de tipo estructural en materia de financiación de vivienda.

En 1999 colapsa el sistema, pues en primer término, el Consejo de Estado mediante sentencia del 21 de mayo de 1999 declaró la nulidad del artículo $1^{\circ}$ de la Resolución externa No. 18 de 1995, en la medida que el cálculo de la UPAC no debía estar ligado a la DTF sino al IPC; ese mismo mes, mediante sentencia C - 383 la Corte Constitucional, declara inexequible el literal f) del artículo 16 de la ley 31 de 
1992, fundamento legal que tenía el Banco de la República para calcular la UPAC con base en la DTF, pues consideró que ésta reflejaba los movimientos de la tasa de interés en la economía, y cuando estos eran superiores al IPC, afectaban el derecho a la vivienda digna.

Cuatro meses después, enfrentando una aguda crisis de orden jurídico, económico y social, es proferida la sentencia C - 700 de septiembre 16 de 1999, mediante la cual, todo el sistema para financiamiento de vivienda basado en la unidad de cuenta UPAC, es declarado contrario a la Constitución, ya que las normas que estructuraban éste sistema de financiación estaban contenidas en decretos expedidos por el Presidente de la República y no en leyes emanadas por el Congreso, organismo que debía de manera exclusiva, expedir la ley marco que estableciera los parámetros generales del sistema de financiación de vivienda.

Teniendo en cuenta las implicaciones económicas de este fallo, los efectos de la sentencia fueron diferidos hasta el 20 de junio de 2000, lapso durante el cual, el Congreso habría de establecer una nueva unidad de cuenta para el sistema de financiamiento de vivienda.

U.V.R.: Sigla de la Unidad de Valor Real, creada mediante Decreto 856 de 1999, unidad de cuenta empleada inicialmente para mantener el poder adquisitivo de dinero invertido en Títulos de Deuda Pública (TES), la cual sería adoptada como unidad de cuenta para todas las obligaciones adquiridas en UPACs, pues, establecer la UVR como unidad de cuenta para el sistema de financiamiento de vivienda, significa que su cálculo se fundamenta exclusivamente en la variación del IPC certificada por el DANE, lo cual garantiza en cierto modo que las deudas 
hipotecarias mantendrán un comportamiento idóneo y de acuerdo a como varíe el IPC.

Con el nuevo sistema de financiación de vivienda, (Ley 546 de 1.999), todas las obligaciones pactadas en UPACs en los contratos de mutuo para financiar vivienda se convertían en UVRs por ministerio de la ley (Artículo 38 Ley 546 de 1999).

Lo anterior quiere decir, que no era necesario cambiar las garantías constituidas por los deudores cuando se celebraron los contratos de mutuo para financiar vivienda con las entidades financieras, pues, el Pagaré y la Escritura Pública de Hipoteca suscrito por los deudores para garantizar los préstamos de dinero pactados en UPAC como garantía de pago de la obligación dineraria, de ninguna manera había que novarlo, cambiarlo o dejarlo sin efecto; para crear 0 constituir nuevas garantías, pues, por ministerio de la ley todo lo que dijera UPAC, debía entenderse UVR.

Por consiguiente, mediante el Decreto 2703 de 1999 reglamentario de la ley 546 de 1999, determinó que una UPAC era equivalente a 160.7750 UVR el 31 de diciembre de 1999, de esta forma las entidades financieras procedieron a efectuar los cálculos matemáticos para establecer al 31 de Diciembre de 1.999, cual era el monto adeudado por los deudores hipotecarios en UVR, teniendo en cuenta que de ahí en adelante todos los cálculos de las obligaciones hipotecarias se establecen en UVR.

Vale la pena aclarar, que las antiguas Corporaciones de ahorro y vivienda, hoy Bancos, tenían que ingresar al nuevo sistema especializado de financiación, procediendo internamente en cada entidad a redenominar los créditos actualizando 
sus bases de datos, migrando los créditos de vivienda a nuevos números de identificación y actualizando los saldos en UVR respectivamente.

LEY DE VIVIENDA: Ley 546 de diciembre 23 de 1999: “ Por la cual se dictan normas en materia de vivienda, se señalan los objetivos y criterios generales a los cuales debe sujetarse el Gobierno Nacional para regular un sistema especializado para su financiación, se dictan medidas relacionadas con los impuestos y otros costos vinculados a la construcción y negociación de vivienda y se expiden otras disposiciones" conocida como "ley de vivienda".

Tuvo la misión urgente de estructurar la nueva unidad de cuenta para el sistema de financiamiento de vivienda, que estuviera ligada exclusivamente al Índice de Precios al Consumidor (I.P.C.), para lo cual se adoptó la Unidad de Valor Real (U.V.R.), que funcionaba para otros sistemas diferentes al de financiamiento de vivienda, y cumplía con el requisito del vínculo exclusivo con el IPC.

Esta ley, mas conocida como "ley de vivienda" quiso solucionar los inconvenientes del sistema para financiación de vivienda - de acuerdo a la Constitución de 1.991 - las condiciones necesarias para garantizar el derecho constitucional a la vivienda digna, a través de la regulación por parte del Gobierno, de un sistema especializado para la financiación de vivienda a largo plazo. También plantea los objetivos y criterios que orientan el nuevo sistema de conformidad con el artículo 2 de la ley de vivienda que dice:

... 1. Proteger el patrimonio de las familias representado en vivienda. 2. Proteger y fomentar el ahorro destinado a la financiación y a la construcción de vivienda, manteniendo la confianza del público en los instrumentos de 
captación y en los establecimientos de crédito emisores de los mismos. 3. Proteger a los usuarios de los créditos de vivienda. 4. Propender por el desarrollo de mecanismos eficientes de financiación de vivienda a largo plazo. 5. Velar para que el otorgamiento de los créditos y su atención consulten la capacidad de pago de los deudores. 6. Facilitar el acceso a la vivienda en condiciones de equidad y transparencia. 7. Promover la construcción de vivienda en condiciones financieras que hagan asequible la vivienda a una mayor número de familias. 8. Priorizar los programas y soluciones de vivienda de las zonas afectadas por desastres naturales y actos terroristas". (p.8)

Otras variaciones introducidas por la ley, consistieron por ejemplo, en reconfigurar el Consejo Superior de Vivienda para determinar entre sus funciones la de calcular y divulgar a diario el valor en pesos de la UVR; convirtió las Corporaciones de Ahorro y Vivienda (CAVs) en bancos comerciales, estableció un nuevo régimen de financiación de vivienda a largo plazo que tomara en cuenta los pronunciamientos de las Altas Cortes respecto a las virtudes y falencias del anterior régimen en UPACs, delineó un nuevo marco para la construcción de vivienda de interés social, y fundamentalmente, el establecimiento de un régimen de transición UPAC - UVR, con el objetivo de ajustar las obligaciones contraídas en UPACs a la nueva figura de la UVR, de lo cual se ocupa el capítulo VIII de la Ley de Vivienda y abarca los artículos 38 a 49, entre los cuales se encuentra, por supuesto, el parágrafo 3 del artículo 42, objeto de la presente investigación. (Farfán, 2002 \& Gracia et al, 1999) 


\section{LEGALIDAD DEL CONTRATO DE MUTUO PARA FINANCIAR VIVIENDA EN ESTADOS UNIDOS}

Llama la atención que mientras en Colombia, tal y como lo vimos anteriormente, para poder celebrar contrato de mutuo para financiar vivienda, se necesita obligatoriamente del contrato de mutuo (Pagaré) más la escritura pública de Hipoteca debidamente registrada en la oficina de instrumentos públicos; en los Estados Unidos, esta operación para financiar vivienda se traduce a un documento denominado "Mortgage", el cual contiene las condiciones del contrato de mutuo y la identificación de la propiedad que va a quedar hipotecada al banco una vez sea registrado dicho documento. Este único documento, se registra en la oficina de registro de instrumentos públicos del estado respectivo y que se denomina popularmente "Public Records".

Vale la pena aclarar que por tratarse de un país federado, las condiciones del préstamo hipotecario pueden variar de estado a estado, pero el nombre del documento se conserva en cualquier estado, es decir, sigue denominándose "Mortgage". Así mismo el nombre de la oficina de registro se podrá denominar popularmente de la misma forma en cualquier estado, "Recording Office", pero, obviamente en cada estado se llamará particularmente de diferente forma, como por ejemplo, en el estado de la Florida, en la ciudad de Miami, esta oficina se llama "Miami Dade County Recorder".

Ahora bien, teniendo en cuenta que los préstamos hipotecarios en Estados Unidos y que se celebran con los bancos se denominan "Mortgage", en primer lugar 
procederé a definir esta figura para luego explicar cada una de sus clases y cómo funcionan.

\section{La Hipoteca en los Estados Unidos}

En Estados Unidos de América, aunque se dan distintas variables y teorías, la hipoteca se traduce con el término "mortgage", que significa transmisión de un derecho real sobre un bien inmueble, realizada por un deudor hipotecario (mortgagor) a un acreedor hipotecario (mortgagee), para permanecer como garantía de cumplimiento de una obligación, normalmente el pago de una deuda documentada en una promesa de pago (promissory note) del deudor hipotecario. (Marshall, 1983)

En todo caso, es un 'derecho de realización' de valor entorno a la posibilidad de apropiación y disposición de los bienes inmuebles, que permite instrumentar entorno a ellos una operación de garantía, más cercana al pacto comisorio que a la realización por medios procesales ad hoc, judiciales o extrajudiciales. (Parra, 1998)

La hipoteca ordinaria (mortgage regular) ha de constar en forma escrita, con especificación de los nombres de las partes y descripción de la propiedad hipotecada. La voluntad de constituir el gravamen hipotecario sobre el inmueble se manifiesta en los estados seguidores de la tittle theory, con las palabras convey and warrant, y en los estados donde rige la lien theory, con las palabras mortgage and warrant. (Marshall, 1983)

El documento ha de reunir los requisitos formales requeridos por la ley estatal para tener acceso al registro. Normalmente, el requisito exigido es la certificación del documento, que suele darse en un simple testimonio de subjetividad, prestado ante 
un notario público que interviene en el sentido de aseverar que conoce a los firmantes y que, efectivamente, las firmas que aparecen en el documento, son suyas. (Parra, 1998)

Ahora bien, es importante describir y explicar cuáles son los tipos de hipoteca que pueden generar el mortgage; en primer lugar, porque dependiendo de la que se escoja, se exigirán determinados requisitos para su constitución y se favorecerán con diferentes tasas de interés aplicable para el caso concreto, y en segundo lugar, porque la utilización desbordada de alguna de ellas y el no pago de las mismas, incidió notablemente en la crisis hipotecaria de EEUU, como veremos más adelante.

A continuación se presentan los instrumentos financieros empleados en el mercado hipotecario residencial y, posteriormente, se describen las principales fuentes de financiación de este mercado, con especial atención a las GSE Fannie Mae y Freddie Mac.

La liberalización del mercado desde finales de los años sesenta favoreció la introducción de una amplia variedad de productos que permitió una adaptación muy flexible a las necesidades de los compradores de vivienda. A grandes rasgos, las hipotecas concedidas se pueden clasificar de acuerdo con los siguientes criterios: las características crediticias del prestatario, el volumen de crédito concedido y el carácter - fijo o variable- del tipo de interés de la hipoteca. (Cuadro, Romo \& Rubio, 2010)

En primer término, atendiendo al riesgo crediticio del prestatario y al volumen de información proporcionado al prestamista, se pueden distinguir tres tipos de hipoteca: prime, subprime y Alt- $A$. Las hipotecas Prime se conceden a prestatarios con riesgo de crédito reducido o moderado y que son capaces de probar sus fuentes 
de ingresos; generalmente, exigen al prestatario un desembolso inicial en el momento de la compra. En el otro extremo, las hipotecas subprime se conceden a consumidores con elevado riesgo de crédito, y en principio, llevan asociados tipos de interés más elevado.

En una categoría intermedia se encuentran las hipotecas near-prime, también llamadas Alternative - $A$ o Alt- $A$. En este caso, aunque el prestatario pudiera tiene un buen historial de crédito, no documenta todos sus ingresos o no realiza un desembolso inicial por la vivienda. La desalineación de incentivos del modelo "originar para distribuir"- que se analiza más adelante- favoreció que algunos prestatarios subprime pasaran por Alt- $A$, bien por su propia iniciativa, o presionados por las practicas agresivas o predatorias de las entidades prestamista.

En una categoría especial estarían las hipotecas FHA y DVA, concedidas a prestatarios con elevado riesgo, aunque garantizadas por la Federal Housing Administration (FHA) en el primer caso y el US Department of Veteran Affairs (DVA) en el segundo, por lo que se podrían considerar dentro de las hipotecas prime. (Cuadro, Romo \& Rubio, 2010)

La categoría dominante es la de hipotecas prime (en torno al $70 \%-75 \%$ del total de hipotecas); y, dentro de estas, las concedidas a tipo fijo. Sin embargo, en los años previos a la crisis el segmento de las hipotecas subprime fue el de mayor desarrollo, con tasas de crecimiento que llegaron a ser superiores al 100\% algún año, de modo que pasaron de representar alrededor de un $2 \%$ de las hipotecas a principios de la década a alcanzar el 14\% del total de hipotecas de 2007 (Cuadro, Romo \& Rubio, 2010). El incremento se produjo principalmente a costa de la 
disminución de las hipotecas FHA y DVA garantizadas, dada la facilidad de acceso que llegaron a tener las hipotecas subprime en relación con las garantizadas.

En segundo lugar, según el volumen de crédito podemos diferenciar entre hipotecas jumbo y non-jumbo. Aunque los limites se revisan con cierta frecuencia, desde 2006 las hipotecas jumbo son aquellas que exceden los 417.000 dólares. Sin embargo, el límite aumentó en 2008 hasta los 729.000 dólares para las áreas de elevado coste de adquisición de vivienda, en el contexto de las medidas de estímulo económico. (Cuadro, Romo \& Rubio, 2010)

Cruzando el volumen y el riego de las hipotecas, se determina si cumplen los requisitos para ser garantizadas por las GSE, las llamadas hipotecas conforming. Estas hipotecas deben ser detentadas por prestatarios con riesgo reducido 0 moderado y ser inferiores a 417.000 dólares, o 729.750 dólares en áreas de elevado coste de adquisición de vivienda. El cuadro 1 resume la clasificación de las hipotecas en función del riesgo crediticio y del volumen de crédito concedido, donde las áreas marcadas en gris denotan las categorías conforming. Las restantes hipotecas serian non conforming y no podrían beneficiarse de las garantías de las GSE. (Cuadro, Romo \& Rubio, 2010)

Otro tipo de clasificación interesante es la derivada del tipo de interés que se paga por ellas: tipo fijo o tipo variable. Desde el punto de vista del hogar prestatario, la ventaja de las hipotecas a tipo fijo es que implican un flujo de pagos estable durante la vida de la hipoteca; sin embargo, suelen tener asociado un tipo de interés más alto, por lo que en un contexto de expectativas de inflación reducida y ancladas, los hogares tenderían a preferir las de tipo variable. Estas tienen otras ventajas para ellos, pues maximizan su poder de compra de vivienda y proporcionan más 
flexibilidad, en particular para hogares que cambian de casa frecuentemente o se mudan antes de que acabe el plazo del tipo fijo.

Desde el punto de vista de las entidades prestamistas, en periodos de estabilidad de precios se ha verificado una proclividad a conceder financiación a tipo fijo; por el contrario, en periodos de elevada inflación esta opción es menos atractiva, pues la evidencia histórica muestra que podría llegar a comprometer la solvencia de las entidades.

Una clase adicional de hipoteca que ha cobrado protagonismo es el periodo previo a la crisis la constituyen las hibridas, por las que se paga un tipo de interés fijo (y, generalmente, reducido) en un periodo inicial (normalmente, uno o dos años), y después se convierten en hipotecas a tipo variable, bastante más elevado que el tipo fijo pagado inicialmente. La principal ventaja de este tipo de hipoteca - en un contexto de continuado aumento en los precios de la vivienda donde la refinanciación es sencilla- es que permite adquirir viviendas de un elevado coste a un tipo muy reducido y que, en principio, se puede refinanciar antes de que se produzca la conversión de tipo fijo (reducido) a variable (mortgage resetting). Este tipo de hipoteca fue usada cada vez más en el segmento subprime, pues ofrecía condiciones muy ventajosas a corto plazo, sin que necesariamente los prestatarios fueran conscientes de las consecuencias de los mayores costes posteriores. (Cuadro, et al, 2010)

Así las cosas, la composición de la masa de hipotecas varia clínicamente, aunque las de tipo fijo tradicionalmente han dominado el mercado hipotecario estadounidense. Además, en los últimos años las de tipo variable fueron ganando peso, hasta alcanzar el $20 \%$ en 2006 . El segmento más dinámico en este grupo fue 
el subprime. Posteriormente, cuando las favorables condiciones económicas desaparecieron y el continuado aumento de los precios de la vivienda revirtió, estos prestatarios se mostraron especialmente vulnerables; en particular, los prestatarios subprime que habían añadido a su vulnerabilidad intrínseca la derivada de las condiciones de su hipoteca (variable o hibrida). A partir del cambio de ciclo, la proporción de hipotecas a tipo variable se ha reducido hasta el 15\%. (Cuadro, et al, 2010) 


\section{RECUENTO HISTORICO SOBRE LA CRISIS HIPOTECARIA EN ESTADOS UNIDOS}

Previo a describir las diversas causas que generaron la crisis hipotecaria en los EEUU, es importante resaltar y como marco de referencia, que a diferencia de aquellas, la crisis en el sistema de financiación de vivienda en Colombia y que fue la que generó el impago de las obligaciones por parte de los deudores hipotecarios, consistió en el cambio de corrección monetaria del IPC al DTF de los créditos hipotecarios que financiaban vivienda; mientras que, en el mercado hipotecario de los EEUU se debieron a una serie de fallas y carencias, en términos de transparencias, información o diligencia, por parte de prestatarios, prestamistas, inversores y supervisores, tal y como lo ilustraremos mas adelante. Para entender mejor lo sucedido, primero relataremos la estructura del mercado hipotecario en los EEUU; luego, miraremos como se desencadenó la crisis como tal y finalmente el impacto y las consecuencias que ello generó.

\section{Estructura del Mercado Hipotecario.}

En sus orígenes, el mercado hipotecario residencial se fundamentaba en un sistema informal de préstamo de comunidades vecinales a individuos, usando la vivienda como colateral. Este sistema evolucionó progresivamente hacia uno fundamentado en una amplia base de prestatarios y un complejo sistema de titularización. Las titularizaciones estadounidenses datan de finales de s. XIX, cuando los primeros bancos hipotecarios emitieron bonos respaldados por hipotecas (Mortgage Backed Bonds (MBB)). (Cuadro, Romo \& Rubio, 2010) 
Ya entonces, los criterios de solvencia acabaron siendo demasiado laxos, de forma que la recesión de 1890 ocasionó un elevado número de impagos que agudizaron el deterioro económico. Posteriormente, el mercado se reconfiguró para asegurar financiación a tipos de interés reducidos, proveer garantías publicas y establecer un sistema de regulación y supervisión más robusto. En este contexto, a lo largo de los años treinta, para mitigar la escasez de crédito hipotecario, se crearon Fannie Mae - que nació como agencia pública- y los 12 Federal Home Loan Banks.

A partir de los años sesenta la titularización volvió a ganar peso progresivamente, el mercado liberalizó y Fannie Mae se privatizó, pasando a ser una GSE; en ese contexto, para evitar un monopolio, se creó una GSE mas, Freddie Mac. Desde los años noventa, la automatización de los procesos de concesión y titularización de hipotecas, la relajación de los estándares de solvencia, el proceso de innovación financiera (que en muchos casos quedaba fuera del ámbito de la regulación) y una cierta laxitud en la supervisión llevaron a una situación de carácter análogo a la de finales del siglo XIX. En este sentido, aunque el desarrollo del mercado hipotecario residencial de las últimas décadas han permitido dar acceso a la vivienda en propiedad a un elevado porcentaje de la población, también ha vuelto a propiciar comportamientos excesivamente arriesgados, con las consecuencias conocidas. (Kovner \& Schoar, 2010)

En efecto, el mercado hipotecario estadounidense experimentó un desarrollo muy acelerado desde inicios de los años ochenta, que además se extendió prácticamente a todo el país, algo inusual en expansiones pasadas. A finales de 2007, el saldo vivo del crédito hipotecario residencial ascendía a 11,2 billones de dólares, equivalente al 79,3\% del PIB, e inferior al 125\% de la capitalización bursátil 
de esta economía, y muy superior al 32\% del saldo vivo de bonos del Tesoro, a finales de ese año. (Kovner \& Schoar, 2010)

Este extraordinario desarrollo, que ha venido acompañado de una diversificación de instrumentos de financiación y de un aumento del número de intermediarios financieros, ha permitido incrementar la ratio de vivienda en propiedad del $64 \%$ al $68 \%$ de los hogares en los últimos 15 años y ha facilitado que parte de la población con rentas más bajas pudiera acceder a una vivienda en propiedad. Así mismo, el desarrollo de modelos de valoración de riesgo propició el incremento de la ratio préstamo- valor, que aumentó notablemente a partir de 2003, en paralelo, incluso, con el fuerte avance de los precios de la vivienda. (Kovner \& Schoar, 2010)

De esta forma, el crédito concedido por hipoteca se incrementó en mayor medida que el precio, lo que podría ser indicio de creciente laxitud de las entidades financieras, incluso tras el cambio de ciclo del mercado de vivienda. La bonanza del mercado hipotecario queda reflejada en el extraordinario dinamismo de las hipotecas: su número aumentó un 96\% entre 1997 y 2007, periodo en el que el número de hogares lo hizo en un $8 \%$, mientras que el volumen de crédito hipotecario se triplicó a la par que el PIB nominal no llegaba a duplicarse. Como se detalla en la sección tercera, esta expansión resultó ser excesiva y, a la postre, insostenible. (Kovner \& Schoar, 2010)

\section{Crisis del mercado hipotecario estadounidense}

El origen de la crisis financiera actual tuvo su epicentro en el mercado hipotecario estadounidense, donde el del ciclo alcista de precios en el sector de la vivienda puso en evidencia sus graves problemas estructurales e hizo aflorar su 
extrema vulnerabilidad. De este modo, algunos de los factores que propiciaron la crisis financiera coinciden con los que estuvieron detrás del derrumbe del mercado hipotecario, que se describen a continuación.

\section{Factores Determinantes.}

Aunque los factores que contribuyeron a la crisis del mercado hipotecario son diversos, existe una serie de fallas y carencias, en términos de transparencias, información o diligencia, por parte de prestatarios, prestamistas, inversores y supervisores, que subyace a este mal comportamiento.

- Inadecuada valoración del riesgo por parte de los prestamistas y problemas de información asimétrica. La supuesta mejora y la sofisticación en los modelos para calibrar el riesgo de crédito, desde los años noventa, dieron acceso a la financiación hipotecaria (en la categoría subprime y en parte de la Alt- $A$ ) a amplios grupos de población que nunca habían tenido acceso a una vivienda en propiedad. (Carlson \& Lindner, 2010)

La calibración del riesgo - por parte de prestamistas, de las GSE y de las agencias de rating- se apoyaban en series cortas de datos, asociados al periodo de expansión económica y con precios crecientes de vivienda. Cuando los precios comenzaron a caer, se produjeron resultados perversos, pues con frecuencia los precios cayeron por debajo del valor de las hipotecas, siendo la mejor opción para el prestatario dejar de pagar la hipoteca, una posibilidad favorecida por el sistema legal de los Estados Unidos.

Además, la existencia de información asimétrica entre prestamista y prestatarios contribuyó significativamente al desencadenamiento de la crisis. El costo real de una hipoteca a lo largo de su vigencia es difícil de calibrar, sobre todo en 
hipotecas a tipo variable; este costo depende, en parte, del comportamiento del prestatario (si realiza alguna devolución anticipada, cláusulas de penalización que se le pueden aplicar, posibles modificaciones de los tipos de interés y comisiones contingentes) lo que aumenta la dificultad para calcular el costo real de la hipoteca en el momento que se solicita. El caso de las hipotecas hibridas (en particular, en el sector subprime) es un buen ejemplo de este tipo de problemas.

Las lagunas de información de los prestatarios - muchos de ellos con escasa cultura financiera- se vieron agravados por la falta de diligencia y la agresividad comercial de algunos prestamistas, que concedieron créditos masivamente, muchas veces a prestatarios de alto riesgo (subprime y Alt- $A$ ), para los que el estallido de la burbuja conllevó un aumento inesperado y sustancial de la carga financiera. (Carlson \& Lindner, 2010).

En éste mismo sentido y trayendo a colación otras fallas en el mercado que generaron crisis, es importante revisar lo que al respecto manifestó el Doctor Mauricio Pérez Salazar, decano de la Facultad de Economía y profesor de las facultades de Derecho y de Finanzas, Gobierno y Relaciones Internacionales, Universidad Externado de Colombia, que dice:

Los principales instrumentos de la regulación financiera responden a dos fallas de mercado, la información asimétrica y la posibilidad, derivada de ella, de problemas de agencia cuando la entidad que capta ahorro del público prefiera sus intereses a los de sus depositantes. La evolución de la crisis, en especial desde el estallido de la burbuja inmobiliaria, indica la existencia de ambos 
problemas y que el marco regulador norteamericano no fue capaz de remediarlos. En el ámbito de la información asimétrica cabe mencionar, entre otros:

- La capacidad de la estructuración financiera de las titularizaciones que se discutió en las secciones anteriores. So pretexto de diversificar el riesgo, quienes la llevaron a cabo lograron una pérdida de información que hace que papeles financieros respaldados por algún valor (mayor o menor, según el caso) no sean negociables. Un esquema diseñado para reducir riesgo lo incrementó de manera exponencial.

- El objeto expreso de las metodologías de titularización en sus diversas capas (RBMS, CDO en sus varias modalidades, SIV) era minimizar la revelación contable del riesgo que asumían las entidades financieras que hacen parte de la cadena del nuevo modelo de negocios de financiación hipotecaria. Con frecuencia la motivación plausible era el "alivio del requisito regulatorio de capital bancario o de gestión de riesgo. Los CDO desparecen el riesgo de esos activos de los estados financieros de su creador, con frecuencia de manera sintética" (Es decir, con el uso de derivados (Gorton, 2008, 16)..

- Derivados como los CDS permitían que las entidades financieras crearan pasivos contingentes (que después se convirtieron en reales) que no registraban en su contabilidad principal sino en las cuentas de orden de sus estados financieros. Esa fue la causa del colapso de AIG. Los graves problemas que enfrentaron los bancos de inversión de Wall Street tuvieron 
mucha relación con sus operaciones de derivados. Una señal de falta de transparencia contable es que los pasivos (no las acciones) de Lehman Brothers, aparentemente solvente hasta días antes de su quiebra a mediados de septiembre, se coticen con un descuento de cerca del $90 \%$.

- Faltaron fuentes confiables de información sobre mercados clave. El índice ABX, elaborado por la empresa privada Markit desde 2006, fue el primer indicador de lo que ocurría en el mercado de titularización hipotecaria residencial de Estados Unidos. Según Gorton, permitió que la información del mercado fuera de conocimiento público; la mayor transparencia contribuyó al estallido de la burbuja (Gorton, 2008, 21-23).

- Un ámbito que trasciende la financiación hipotecaria es el de los derivados o "swaps", que entre 2002 y 2008 pasó de US\$ 106 a US\$ 531 billones (cifra equivalente a cincuenta veces el PIB de Estados Unidos) según el New York Times. A finales de los noventa la encargada de la regulación del mercado de derivados en Estados Unidos, la señora Brooksley Born, propuso examinar posibles medidas en esta área, entre ellas sistemas de información de las transacciones y una cámara central de compensación. Enfrentó una férrea oposición de Wall Street, del Departamento del Tesoro y de Greenspan, con el argumento de que aniquilaría en su cuna un mercado incipiente. Debido a esa oposición tuvo que dejar el cargo y no se hizo nada. Buena parte de la turbulencia financiera actual se debe a que no se sabe mucho del mercado en su conjunto ni de la exposición de actores individuales al riesgo de derivados. 
- Por último, el efecto de la información asimétrica en el contagio a otros mercados; ya no la asimetría entre captador y depositante sino la que es ocasionada por la desaparición de los mercados de activos que hacen parte importante del balance de los participantes en el mercado interbancario. La "vigilancia del riesgo de contraparte", para usar la expresión de Greenspan, se vuelve una misión imposible. Especialmente si cada banquero sabe que tiene esqueletos más o menos escondidos en sus propias cuentas. Es natural que se pregunte por los de sus colegas, cuando esos esqueletos tienen un descuento de precio de un $90 \%$ en relación con los valores nominales o contables.

Sobre el segundo punto, el de los márgenes adecuados de capitalización con respecto de sus pasivos, cabe destacar los siguientes hechos:

- La falta de transparencia de la contabilidad, por las razones antes señaladas, lleva a que cualquier sistema diseñado para limitar el apalancamiento pierda al menos parte de su eficacia. En particular, hay que recordar que muchas titularizaciones hipotecarias no tienen precios de mercado.

- Aún así, el requisito de tener una proporción razonable de capital en relación con los activos se había desdibujado en la práctica. Christopher Cox, presidente de la Securities and Exchange Commission (SEC), dijo de uno de los bancos de inversión que tuvo que ser adquirido por JP Morgan Chase para evitar su colapso: "Aún en el momento de su venta el domingo, el patrimonio de Bear Stearns [...] superaba las exigencias regulatorias" (citado en Morris y 
Shin, 2008, 3). A finales de 2007, el patrimonio de Bear Sterns y el de Lehman Brothers sólo equivalían al 3\% de los activos, una relación de apalancamiento de 33 veces. Citigroup, que como banco comercial tiene un régimen regulador más estricto y que ha adquirido varias entidades financieras en problemas durante 2008, tenía una relación de apalancamiento de 20 veces a finales del año anterior.

- Este hecho tiene como antecedente la decisión de la SEC, adoptada en abril de 2004, de eliminar la exigencia de patrimonio mínimo (es decir, el límite de apalancamiento) a los grandes bancos de inversión. En una reunión a veces interrumpida por risas, los comisionados hicieron comentarios como "Hemos dicho que estos son los grandes, pero eso quiere decir que si algo falla habrá un lío terriblemente grande" y "Estoy muy contento de apoyar la propuesta, y mantendré cruzados los dedos" antes de aprobar la medida por voto unánime (Ver en http://www.nytimes.com/2008/10/03/business/03sec.html la grabación de la reunión). En los cuatro años siguientes la relación de apalancamiento de Merrill Lynch pasó de 17 a más de 30, para poner un ejemplo.

La desregulación que llevó a esta situación pretendía impulsar la innovación financiera, y en retrospectiva algunos de los argumentos que la apoyaron parecen ironías orwellianas. La eliminación de los límites de apalancamiento se hizo en aras de un "uso más eficiente del capital" de las firmas beneficiadas. En todo caso, no fue un proceso espontáneo. Hubo un vigoroso cabildeo de las entidades financieras que tuvo una calurosa acogida de la 
persona que ocupaba la cúspide del aparato regulador, Alan Greenspan. Se podría hablar incluso de una captura del regulador por los regulados: muchos de los altos funcionarios del gobierno Bush provienen de la banca de inversión, en especial de Goldman Sachs.

También hubo un círculo vicioso de competencia en materia de laxitud regulatoria: según se decía entonces, si los estándares aplicables en Nueva York eran más estrictos que los de Londres, se perdería "competitividad" con respecto a esa plaza. $\mathrm{Y}$ el argumento inverso se usaba en Londres, con consecuencias idénticas. No resultan sorprendentes las afinidades de las crisis en las dos costas del Atlántico.

Gary Gorton hace un balance de los resultados en los siguientes términos:

El pánico de hoy no es un pánico bancario, en el sentido de que el sistema bancario tradicional no enfrentó, inicialmente, corridas bancarias como en pánicos anteriores. Pero hemos sabido durante mucho tiempo que el sistema bancario estaba transmutándose en un mundo de "fuera del balance" y de derivados, en un sistema bancario la sombra $(2008,33)$.

La ideología desregulacionista que propició el surgimiento de ese sistema bancario a la sombra en muchos casos fue un disfraz de un pésimo análisis económico que desconoce la existencia de fallas de mercado elementales para entender la actividad financiera: asimetría de información y riesgo moral. (p 24-30) 
Adicional a lo que plantearon los autores anteriormente mencionados, pero en este mismo sentido, Herman Schwarts, en su escrito denominado "Subprime Nation" dice:

Aparte de las fallas de la estimación econométrica del riesgo crediticio, el diseño de la estructuración financiera propiamente dicha tuvo consecuencias inesperadas y contraproducentes. La complejidad de su estructura fue descrita por Gorton (2008) y se puede entender como una serie de capas superpuestas en cuya base están los créditos hipotecarios individuales. La capa siguiente se denomina RMBS (residential mortgage backed securities o títulos respaldados por hipotecas residenciales), cuya arquitectura implica la agregación de hipotecas (o fragmentos de hipotecas) de diversa calificación, incluyendo un componente de créditos subprime y $A l t-A$, en su mayoría de tasa de interés ajustable. Para proyectar el flujo de caja de RMBS, un supuesto clave era que los deudores de hipotecas ARM refinanciarían sus créditos al terminar el periodo de tasa preferencial. Con eso se debían lograr dos resultados: con el dinero de la nueva hipoteca se prepagaba el saldo de la anterior, acelerando la amortización en favor de los tenedores de RMBS; y la nueva hipoteca se volvía materia prima para nuevas titularizaciones, generando nuevas comisiones para todos los eslabones de la cadena. La siguiente capa está formada por CDO (collateralized debt obligations o títulos de crédito colateralizados). Un CDO se crea para adquirir una cartera de RMBS y luego vender bonos propios. En la estructuración de estos últimos, los ingresos esperados de cada RMBS se dividen en varios tramos, según el nivel de riesgo de la cartera hipotecaria subyacente. Además de los CDO reales, también existen CDO sintéticos (que compran y venden ya no RMBS sino 
derivados de RMBS, especialmente CDS -credit default swaps- y CDO híbridos que combinan las dos modalidades). Pero, lo más grave, la pérdida de información debida a la complejidad de la estructuración lleva a que los inversionistas carezcan de cualquier otra base razonable para valorar esos activos. Nadie sabe -ni tenedores ni vendedores ni compradores- cuánto vale (en valor presente del flujo futuro de ingresos) un RMBS, un CDO, un SIV o los derivados de estos papeles. Y eso lleva a un fenómeno común en las etapas finales de las burbujas: desaparece el mercado. No hay demanda salvo a precios irrazonables. La pérdida de información debida a los métodos opacos de titularización hace que el mercado valore hoy la mejor cartera comercial (que hasta ahora tiene una proporción de cartera vencida del orden del $1 \%$ ) en un nivel similar al del escenario hipotético y pesimista del método para idiotas para la totalidad de la cartera hipotecaria: $30 \%$ de descuento." (p. 191).

Hemos visto que los autores antes descritos hacen alusión al fenómeno de la burbuja. Para explicar a fondo en que consiste esto, revisemos nuevamente algunos apartes del ensayo del Doctor Mauricio Pérez Salazar, donde expresa:

El análisis que sigue examina algunos aspectos conceptuales de las burbujas en los mercados de activos, las funciones del sector financiero en una economía de mercado, los problemas básicos de la regulación financiera y el caso específico de los mercados de crédito hipotecario. Luego describe los rasgos del cambio en el modelo de negocios de este mercado en Estados Unidos que desencadenaron una crisis financiera más amplia. Al final se 
examinan las respuestas de política que hasta ahora se han dado a la crisis y se concluye con algunas conjeturas sobre sus consecuencias.

\section{EL CICLO DE VIDA DE UNA BURBUJA}

Quizá la mejor demostración de que los agentes económicos no siempre actúan de manera racional son las pirámides financieras que se promueven en pueblos y ciudades intermedias (y a veces en las capitales) de Colombia. Un financista astuto empieza a pagar tasas de interés muy superiores a las de usura; se difunde la noticia y acuden en masa los clientes. Parte de su propuesta de venta es el cumplimiento religioso de sus obligaciones. Pero hay un problema invisible para los felices ahorradores: el financista no tiene forma de colocar lo que capta en inversiones tan rentables que cubran la elevada tasa de interés junto con sus costos de operación. El financista paga intereses a los clientes antiguos con el capital que consignan los más recientes.

El esquema perduraría si hubiese infinitos recursos captables de clientes nuevos. Pero como no hay infinitos en los mercados reales, un día el local del audaz financista amanece cerrado ante una multitud de ahorradores, estafados e iracundos. El esquema de financiación piramidal o Ponzi, como se conoce en la literatura, demuestra que los individuos a veces actúan con base en expectativas muy alejadas de la realidad, en otros términos, que son irracionales. Paradójicamente, la misma sabiduría popular ilustra esa irracionalidad: el refrán castellano "de eso tan bueno no dan tanto", y también la expresión popularizada por Milton Friedman para aludir a la escasez: "no 
hay almuerzo gratis". El pánico de 2008 es a su manera la pirámide pueblerina en gran escala.

La teoría convencional, la misma que supone que los agentes siempre actúan de manera racional, predice que el precio de un activo (algo que se adquiere por su capacidad productiva y no para el consumo inmediato) equivale al valor presente neto de los flujos futuros de ingresos. Esa valoración depende en parte del retorno esperado y en parte del riesgo asociado con el activo: la probabilidad de que el flujo real sea menor que el previsto o que deje de existir. Para la valoración el agente tiene en cuenta la mejor información disponible en el momento de comprar o vender el activo. Por supuesto el precio de mercado del activo cambia a medida que se adquiere información adicional: elementos de juicio más completos acerca del futuro flujo de ingresos. Eso es lo que hace que los precios de los activos suban y bajen.

¿Qué caracteriza a una burbuja en un mercado de activos? En una burbuja como la que vivió el mercado norteamericano de financiación hipotecaria hay una ruptura. Se rompe el vínculo entre el precio actual del activo y lo que puede producir en términos del flujo esperado de ingresos futuros. Según la etapa de la burbuja, el precio de mercado puede ser muy superior o muy inferior al valor subyacente del flujo de ingresos esperado.

Tolstoi empezó su novela Ana Karenina con la frase: "Todas las familias felices son parecidas; cada familia infeliz es infeliz a su manera". A diferencia de las familias, todas las burbujas son a la vez parecidas y diferentes (Un 
excelente referente teórico y empírico de la historia de las burbujas en los mercados de activos es Kindleberger y Aliber (2005), cuyo análisis se sigue en esta sección). La que primero se documentó ocurrió en Ámsterdam en 1636, en ese entonces la primera plaza financiera del mundo. Los activos en cuestión eran, aunque parezca inverosímil, bulbos de tulipán. Cuando estalló hubo una gran contracción económica (Kindleberger y Aliber, 2005, 99-100).

Las burbujas tienen tres etapas. En la primera surge una tendencia alcista de precios, por alguna circunstancia macroeconómica (p. ej., tasas de interés muy bajas) o microeconómica (una escasez transitoria del activo). A diferencia de lo que ocurre en mercados normales, el alza de precios dispara la demanda. Los activos se valorizan cada vez más; la gente está dispuesta a comprarlos precisamente porque los precios suben, y tiene la expectativa de que seguirán haciéndolo.

La conducta de los inversionistas durante la primera etapa de la burbuja es un ejemplo de las profecías que se cumplen a sí mismas, explicadas así por el sociólogo Robert Merton:

La profecía que se cumple a sí misma es, al principio, una definición falsa de la situación que suscita un nuevo comportamiento que hace que la falsa concepción original se vuelva verdadera. La engañosa validez de la profecía que se cumple a sí misma perpetúa un reinado del error, pues el profeta citará los eventos sucedidos como prueba de que tenía la razón desde el principio (Merton, 1968, 477). 
Las alzas de precios del activo atraen a nuevos inversionistas, y a medida que éstos llegan al mercado se fortalece la demanda y el activo -0 el tipo de activos- se valoriza aún más. Si se generaliza la expectativa de que invertir en cierto activo es un buen negocio, esa esperanza será durante algún tiempo una profecía que se cumple a sí misma, a pesar de que los precios lleguen a niveles que no corresponden con su valor real o valor presente de los ingresos futuros que puede generar.

El número de inversionistas en el mercado del activo se amplía de manera paulatina. Los pioneros quizá son los que mejor conocen el mercado y por ello ingresan cuando los precios son relativamente bajos. Luego, cuando corre la bola de que "eso es con seguridad un buen negocio", llegan inversionistas menos informados y menos audaces. Después viene la fase de "todo el mundo lo está haciendo": acuden aun los más ignorantes y aversos al riesgo. Paradójicamente, esa coyuntura -la de los precios más inflados- es la más riesgosa. Como señala Karl Case, a propósito del cambio de tendencia del mercado hipotecario de Estados Unidos:

El momento óptimo para frenar la suscripción de hipotecas es precisamente cuando los precios inmobiliarios están al alza. Los créditos concedidos en el pico son los más vulnerables, aunque en ese momento las tasas de morosidad sean mínimas. (Case $(2008,23)$. La conducta de los inversionistas, en especial de los que llegan tarde, se puede denominar comportamiento de manada; ver Herrera (2005)). 
Entre otras razones, porque la expansión de la burbuja ha atraído no sólo a inversionistas incautos sino a negociantes inescrupulosos interesados en aprovecharse de su ingenuidad (La etapa inicial de las burbujas especulativas suele ser un caldo de cultivo propicio para fraudes y estafas; ver los numerosos ejemplos de Kindleberger y Aliber (2005, cap. 9)).

En algún momento, hay un cambio en la tendencia de los precios que puede ser precipitado por un hecho exógeno. Estalla la burbuja. En el punto de quiebre, o poco antes, algunos inversionistas se dan cuenta de la pérdida de correspondencia entre el precio de los activos en el mercado y el valor presente de los flujos futuros de ingresos que pueden esperar de ellos. Lo uno ya no tiene que ver con lo otro.

La tercera etapa, la final, es la salida de inversionistas del mercado, que sigue un proceso simétrico al que se ha descrito. Aunque al principio vendan pocos, los precios dejan de subir y luego empiezan a bajar. Cuando un número cada vez mayor de inversionistas se percata de que la valorización del activo (lo que los atrajo al mercado) se ha revertido, la salida se convierte en fuga, y luego en desbandada.

La salida se manifiesta en una reducción de los precios que genera otra profecía que se cumple a sí misma: la caída seguirá irremisiblemente. Hay dos agravantes después del estallido. No sólo caen los precios, tampoco hay mercado, es decir, no hay compradores (Técnicamente, siempre hay compradores si el precio es suficientemente bajo; en la jerga de Wall Street se 
denominan inversionistas buitres. Pero lo que se registra en esos casos es la falta de compradores a precios que no sean irrazonables. Ver algunos ejemplos históricos en Kindleberger y Aliber (2005, 178-180) ). La falta de liquidez extrema acelera la caída de los precios, en especial cuando hay vendedores involuntarios: inversionistas obligados a vender por la presión de sus acreedores. Este hecho es uno de los rasgos más preocupantes de la crisis actual, como se verá más adelante. El otro problema es el cambio en la percepción del riesgo y en la actitud de los agentes hacia el riesgo. En la última etapa de las burbujas la transformación es radical. Quienes eran propensos o incluso neutrales al riesgo se vuelven muy aversos al riesgo; se hacen irracionalmente temerosos. De ahí que la palabra "pánico" se pueda aplicar en sentido literal a las crisis financieras producto del estallido de una burbuja. El cambio de actitud suele ser duradero y dificulta la recuperación.

- Desarrollo excesivo e inadecuado del modelo "originar para distribuir". La expansión de las titularizaciones - que subyacen a la mayor parte de la financiación hipotecaria- favoreció un modelo de mercado donde el originador no retenía ningún riesgo sobre el activo subyacente, el llamado modelo "originar para distribuir" que derivó en una inadecuada alineación de incentivos.

A priori resulta difícil de explicar la elevada demanda de titularizaciones por parte de los inversores, dada la insuficiente garantía que pedían los originadores de hipotecas a sus clientes subprime, hipotecas sobre las que no conservaban ningún riesgo en sus balances. 
La demanda se justificaba por la creencia- ilusoria- de que el proceso de titulización y empaquetado de hipotecas permitía redistribuir los riesgos individuales; de forma que se eliminaba el riesgo sistémico. Esta percepción errónea sobre la asunción y distribución de riesgos, que afectó sobre todo a las titularizaciones más complejas, estaba respaldada por el juicio- erróneo a posteriori y, en muchos casos, emitido de modo negligente y sesgado- de las agencias de calificación crediticia. (Carlson \& Lindner, 2010)

Este conjunto de circunstancias fomentó la demanda de activos complejos y, simétricamente, la capacidad de financiación a coste reducido, propiciando un incremento excesivo de la financiación hipotecaria en la fase expansiva. Este proceso fue socavando la estabilidad del mercado de titularizaciones $\mathrm{y}$, por extensión, del hipotecario, que finalmente se derrumbó. Como es bien conocido, la amplia diseminación de estas titularizaciones complejas a través del sistema financiero ha sido uno de los principales factores explicativos de la inusitada virulencia de la crisis financiera.

\section{Fallas de regulación y supervisión}

Estos problemas y fallos del mercado se podrían haber evitado o, al menos, mitigado si la regulación hubiera sido la adecuada y, sobre todo, si la supervisión del mercado hipotecario y, más en general, del sistema financiero y del modelo "originar para distribuir" se hubiera llevado a cabo satisfactoriamente. Desde el punto de vista regulatorio, el contexto económico y financiero expansivo favorecía una regulación poco exigente, que no limitara el crecimiento y la sofisticación de los mercados. 
De este modo, el desarrollo y la expansión de mercados e instituciones financieras al hilo de la innovación quedaron fuera del perímetro regulatorio (Shadow banking), propiciando un crecimiento excesivo.

Esta falta de regulación generó lagunas en la supervisión, potenciada por la propia complejidad de esta banca en la sombra y por su carácter sistémico. La propia situación de bonanza de los mercados favoreció una cierta laxitud también en este ámbito, que no es justificable dada la diligencia que debe guiar a las autoridades supervisoras.

Por último, la atomización de la supervisión y a hacerla menos eficiente. Un ejemplo bien conocido de estos problemas fue la posibilidad de mantener los productos complejos en vehículos fuera del balance de las entidades y, por lo tanto, fuera de la supervisión, lo que se reveló, a posteriori, como un grave error, compartido por la mayoría de supervisores en el mundo, siendo el caso español una excepción. (Carlson \& Lindner, 2010).

El autor Colombiano Humberto Pérez Salazar, al respecto, en su artículo sobre el origen del pánico de 2.008, opina:

El sector financiero y el mercado de capitales son indispensables para el funcionamiento de una economía moderna. Por eso es tan peligrosa la crisis de hoy y tan urgente una respuesta adecuada de política. Una crisis financiera no resuelta es el equivalente económico de una bomba de neutrones. Luego del estallido quedan intactos los edificios y las fábricas, la riqueza física, pero 
desaparece la actividad económica. Así ocurrió en Estados Unidos en los primeros años de la Gran Depresión (1929 a 1933).

¿Qué hacen el sector financiero y el mercado crediticio? Cumplen cuatro funciones: la transaccional, la intermediación de crédito, la diversificación del riesgo y la transformación de plazos.

Los agentes económicos usan los servicios del sector financiero para recibir y hacer pagos. No sólo aprovechan la infraestructura del sistema (oficinas, cajeros automáticos, red de corresponsales, etc.) sino que el grueso de las transacciones que realizan depende del buen crédito de los bancos. La proporción de las medidas más amplias de los medios de pago que corresponde a emisión primaria de los bancos centrales es pequeña.

El sector financiero recibe recursos de un gran número de ahorradores y los transfiere en forma de créditos a quienes los requieren para hacer inversiones o para otros propósitos, como el consumo durable. Cuando funciona bien, el sector financiero ofrece a los primeros un vehículo seguro para sus ahorros y los canaliza a los titulares de proyectos de inversión rentables; propicia así un uso eficiente del ahorro de la sociedad que hace posible el crecimiento económico. La intermediación reduce los costos de transacción que tendrían unos y otros en un mundo desintermediado.

La diversificación del riesgo es posible por la escala del establecimiento financiero y está asociada a su labor de intermediación. Se puede concebir un mercado de crédito sin intermediarios financieros. Un ahorrador individual 
podría hacer negocio con un prestatario individual, pero encontrarlo sería dispendioso. No sería fácil hallar un cliente cuyas necesidades de crédito, en términos de plazo, monto y modalidad de amortización correspondan exactamente a sus preferencias. Además, el acreedor tendría un problema de concentración de riesgo.

Si uno le presta todos sus ahorros a un amigo para que monte una fábrica de zapatos, le puede ir bien como le puede ir mal. Si le va mal, el ahorrador sufre una pérdida total. Si el banco que recibe ese dinero en depósito presta a cien empresas de calzado, la expectativa razonable es que a la mayoría le vaya bien, aunque unas pocas tengan problemas. $Y$ ese riesgo, disperso, es cubierto por el margen de intermediación del banco. Además, el banco quizá haga mejor la labor de evaluación del riesgo de cada crédito de su cartera que un ahorrador común y corriente. En teoría tiene mejores herramientas para la gestión del riesgo.

La última función esencial del sistema financiero es la transformación de plazos. Los bancos reciben depósitos a corto plazo y luego los invierten en cartera de créditos u otros activos financieros de largo plazo. El tamaño de los bancos y la amplitud y diversidad de su base de depositantes les permite hacer esa transformación de tal manera que se pueden dar el lujo de tener una cartera relativamente ilíquida pero solvente y rentable, sin correr el riesgo de quedarle mal a sus depositantes cuando acudan individualmente a retirar sus ahorros (Una advertencia: si bien este análisis se refiere a bancos y otros intermediarios financieros para simplificar la exposición, hay otros vehículos 
en el mercado de capitales que pueden cumplir funciones similares y ofrecer servicios comparables a los ahorradores. Pero no son sustitutos perfectos. )

Para que el sector financiero pueda cumplir estas funciones, y en particular la última, la transformación de plazos, requiere confianza. El ahorrador recibe promesas a cambio de su dinero. ¿Qué respalda esas promesas? En principio la probidad, la solvencia y la idoneidad del banquero. No obstante, la experiencia histórica demuestra que la confianza necesita el respaldo adicional de un regulador externo, que normalmente es público.

Sin entrar en minucias, el sistema de regulación financiera tiene un objetivo claro y dos principios básicos, que a su vez obedecen a sendas fallas del mercado. El objetivo es proteger los intereses del ahorrador, dar al ahorrador la confianza de que volverá a ver el dinero que entregó al banquero y que lo volverá a ver en las condiciones pactadas.

Entre el ahorrador y quien capta su dinero hay asimetría de información, la primera falla de mercado. El ahorrador sabe que entrega dinero a un banco y que éste lo invertirá en créditos y otros activos financieros que respaldarán la deuda con sus depositantes. El ahorrador no tiene forma de saber exactamente cuáles son los activos en que invierte el banquero ni su perfil de riesgo, es decir, tiene dificultades para juzgar el riesgo que asume cuando consigna dinero en un banco dado. De allí la necesidad de que el regulador imponga al banquero la obligación de ser transparente en cuanto a la estructura y las características de sus activos y pasivos. Eso implica 
suministrar al público información completa, fidedigna, oportuna y precisa acerca de la estructura de sus activos y responsabilidades frente a terceros, para no hablar de pérdidas y ganancias que afecten la solvencia patrimonial del banco. Aunque no elimina del todo la asimetría de información, esta condición permite a los ahorradores una elección racional, por ejemplo entre un banco con alta rentabilidad y riesgo y otro con bajos niveles en ambos indicadores. También les permite cambiar la composición de su portafolio personal de inversiones a medida que varía la exposición al riesgo de los captadores de ahorro.

La segunda falla de mercado, el riesgo moral, es consecuencia de la asimetría de información. ¿En qué consiste el riesgo moral en este contexto? En que el banquero, en vez de obrar como el obediente, juicioso, competente y sobre todo honesto agente del ahorrador, sobreponga su interés propio al de éste. Por ejemplo, que invierta los ahorros del público en proyectos de muy alto riesgo, donde tiene la posibilidad de hacerse a una parte desproporcionada de la alta rentabilidad si son exitosos, mientras que traslada las pérdidas al ahorrador si fracasan.

Para alinear los incentivos del banquero con los de los ahorradores, el segundo principio de la regulación prudencial ofrece una solución muy sencilla: exigir al intermediario financiero que mantenga un patrimonio cuyo monto depende de sus pasivos con el público. ¿Qué se logra con esto? Que si hay pérdidas por desvalorización del portafolio de activos del banco, se carguen a su patrimonio. El patrimonio requerido es un colchón que protege a 
los depositantes de los golpes que puedan causar los errores del banquero. La regla de distribución de pérdidas es: $100 \%$ para el banco y 0\% para el ahorrador. Cualquier pérdida deteriora la base patrimonial del banco sin que afecte necesariamente a sus pasivos. Con esta norma, el patrimonio exigido se debe reponer con capital fresco. Para tales casos hay un corolario, también sencillo: si el banquero perdió dinero y no tiene cómo recapitalizarse, ¡de malas! El regulador interviene el banco y la intervención se basa en ese principio sagrado: debe perder el banquero mas no el ahorrador. Es un asunto de responsabilidad de los accionistas y de los administradores de los bancos.

En el curso de la crisis financiera de 2008, la aplicación de la norma de responsabilidad ha sido más la excepción que la regla. Los reguladores olvidaron la sabiduría del diálogo hipotético entre un banquero y su regulador. El banquero pregunta: "Si yo le dijera que mi entidad tiene graves dificultades, ¿qué haría?". El regulador responde: "Analizaría el asunto con su sucesor".

\section{Impacto y consecuencias}

Los signos de empeoramiento del mercado hipotecario que aparecieron desde el inicio de la caída de precios de la vivienda, a finales de 2006, se agravaron con el estallido de las turbulencias financieras en el verano de 2007 - originadas, precisamente en las titularizaciones subprime-, alcanzando una situación límite en septiembre de 2008 con la intervención de Fannie Mae y Freddie Mac y, una semana después, con la quiebra de Lehman Brothers. El proceso de implosión solo se frenó a 
lo largo de 2009, después de la extraordinaria respuesta de la política monetaria, fiscal y de apoyo al sector financiero e hipotecario.

La corrección del precio de la vivienda ya había completado la mayor parte de su recorrido antes de septiembre de 2008 , con una caída del $21 \%$ desde el pico (a finales de 2005); la tasa de morosidad pasó del $4.7 \%$ al $7 \%$, y las condiciones de acceso al crédito se endurecieron hasta niveles desconocidos (más del $70 \%$ de los bancos encuestados declaraba estar endureciendo el acceso al crédito hipotecario). El flujo de crédito experimentó una contracción desde el segundo trimestre de 2008, que aún continúa en 2010.

En cuanto a los tipos de interés, el diferencial entre el tipo fijo hipotecario a 30 años y el tipo objetivo de la Reserva Federal aumentó en 4.3. puntos porcentuales (pp) entre enero y noviembre de 2008 , aunque el inicio de la escalada se produjo a mediados de 2007, con el tensionamiento de los mercados interbancarios, reflejado en el diferencial del LIBOR. A pesar de la reducción de las tensiones en los mercados financieros desde mediados de 2009, el diferencial de los tipos hipotecarios ha aumentado y aun mantiene en niveles históricamente elevados, si bien hay que tener en cuenta que el tipo de interés oficial también está en mínimos históricos.

La creciente morosidad de las hipotecas redujo su valor $-\mathrm{y}$ el de las titularizaciones-, erosionando fuertemente la solidez financiera de Fannie Mae y Freddie Mac, así como la del resto de los agentes del mercado, con la diferencia de que aquellas disfrutaban de unos costes de financiación menores, pues contaban con la percepción de garantía implícita por parte de los inversores. 
La infracapitalización de estas entidades, en un contexto de crecientes ejecuciones hipotecarias, generó dudas sobre la fiabilidad de esta garantía, y sus acciones perdieron el $90 \%$ de su valor entre octubre de 2007 y septiembre de 2008 . En este momento se produjo la intervención por el Tesoro y su supervisor, la Federal Housing Finance Agency, bajo la figura legal del Conservatorship, cuyo mandato principal es estabilizar y sanear las compañías para devolverlas a su funcionamiento normal. Entre las medidas adoptadas, se inició un proceso de recapitalización para evitar que su patrimonio neto fuera negativo, y en marzo de 2010 ya se habían inyectado $147 \mathrm{~mm}$ de dólares en las dos entidades. (Kovner \& Schoar, 2010)

Pocos meses más tarde, en noviembre de 2008, la Reserva Federal activó sendos programas de adquisición de deuda emitida por GSE (Fannie Mae, Freddie Mac y los 12 Federal Home Loan Banks) por 100 mm de dólares, y la compra de titularizaciones hipotecarias garantizadas por Fannie Mae, Freddie Mac y Ginnie Mae por $500 \mathrm{~mm}$ de dólares, con el objetivo de contribuir a la reducción de los spreads hipotecarios. (Kovner \& Schoar, 2010)

Los importes se revisaron al alza en marzo de 2009, hasta $200 \mathrm{~mm}$ y 1.25 billones de dólares, respectivamente. Un año después, al finalizar el plazo de estos programas, las compras se habían completado en su totalidad, con la excepción de la deuda de agencias, cuya cifra final ascendió a 175 mm de dólares- frente a los 200 mm de dólares posibles- para evitar distorsionar el funcionamiento de este mercado. En conjunto, las adquisiciones del Tesoro y de la Reserva Federal se elevaron a 1.63 billones equivalentes al $12 \%$ del PIB, y al $20 \%$ del saldo vivo del mercado de títulos de agencia, donde la Reserva Federal llegó a comprar 1.43 billones en deudas y MBS, y el Tesoro, 200 mm de dólares en MBS. (Kovner \& Schoar, 2010) 
Estas medidas, aunque forzadas por las circunstancias financieras de las GSE, se enmarcaron en un amplio programa de apoyo al sector de la vivienda, como parte de la respuesta integral de política económica para mitigar el impacto de la crisis. De hecho, dada su centralidad en el sistema, el papel de las GSE ha resultado determinante para mitigar la caída del crédito hipotecario, pues prácticamente han compensado la reducción del flujo de otra financiación mediante el aumento de los MBS garantizados por ellas.

En conjunto, la suma de las titularizaciones garantizadas por las GSE y de las hipotecas que tiene en cartera constituye el $52 \%$ del crédito hipotecario para hogares (7 pp más que en el segundo trimestre de 2008). Por otro lado, la recapitalización de las entidades logró sostener la confianza de los inversores, mientras que el anuncio y la posterior compra de los títulos habrían reducido los tipos hipotecarios entre 80 puntos básico (pb) y $100(\mathrm{pb})$.

Todas estas medidas extraordinarias resultaron claves para estabilizar el mercado de la vivienda. Los precios tocaron fondo en el primer trimestre de 2009, con un descenso del $32 \%$ desde el pico; y, desde entonces, la actividad del mercado de la vivienda comenzó a mostrar síntomas de estabilización en niveles bajos. Sin embargo, la debilidad del mercado laboral contribuyó al continuado ascenso en la tasa de impagos hipotecarios, que en 2010 ha superado el 10\% de las hipotecas, al tiempo que las hipotecas en proceso de ejecución ascienden al $4.6 \%$, indicios de que el ajuste del mercado hipotecario e inmobiliario aun no ha concluido. (Kovner \& Schoar, 2010) 
En los incisos anteriores, se hizo alusión a las ejecuciones hipotecarias como efecto lógico de la crisis, pero no se revisó, como se desarrolla dichas ejecuciones en Estados Unidos; por ello, procederé brevemente a revisar el modo de ejecución.

Modo de ejecución de la hipoteca

Recordemos que la diferencia principal entre las dos tesis mayoritarias, la tittle theory, con las palabras convey and warrant, y en los Estados donde rige la lien theory, con las palabras mortgage and warrant, está en el modo de ejecución "manner of foreclousure en tanto que en el sistema del title theory el acreedor hipotecario tiene el título (property) porque ha habido convey (entrega o venta en garantía).

En el sistema de lien theory estamos ante un simple gravamen o carga impuesta a la propiedad inmobiliaria para seguridad de una obligación. Por tanto, en aquellos estados de la unión en que la ley aplicable confiere a la formalización de la hipoteca (mortgage) naturaleza de title theory, el modo de ejecución (method of foreclousure) será predominantemente una especie de power of sale (poder de venta), venta en garantía, o fiducia a modo de pacto comisorio. En los estados del sistema de lien theory será precisa en cambio la ejecución mediante realización bajo tutela judicial de la carga real (lien) que se impuso con fines de garantía.

En cuanto a los tipos de interés de los préstamos hipotecarios, una gran mayoría de los nuevos préstamos hipotecarios son de interés fijo por un periodo de 3 a 5 años y los restantes 27 ó 25 años son variables. Esto está causando muchas pérdidas hipotecarias que conllevan "foreclousures": juicios o remates judiciales hipotecarios y que han llevado al mercado inmobiliario norteamericano a lo que se denominó 2007 credit crunch. 
Con el fin de evitar la entrega de préstamos hipotecarios de difícil recuperación, muchas organizaciones sin ánimo de lucro relacionadas con la industria inmobiliaria de los Estados Unidos han implementado códigos de ética diseñados para definir la entrega de los préstamos en condiciones equitativas y confiables.

Medidas Adoptadas para la estabilización del mercado de vivienda en Estados Unidos.

Los programas de apoyo al mercado de la vivienda en Estados Unidos han tenido como objetivo, en primer lugar, facilitar el acceso al crédito hipotecario y a la compra de viviendas, y, en segundo término, prevenir ejecuciones de hipotecas. Dichos programas, fueron iniciados con la intervención de Fannie Mae y Freddie Mac en septiembre de 2008.

Dentro del primer grupo de medidas, entre las que cobran protagonismo las GSE, pueden distinguirse:

- El soporte que Fannie Mae y Freddie Mac están prestando al mercado de la vivienda, permitiendo una mayor concesión de financiación a menor coste. Así mismo, la Federal Housing Administration ha intensificado su labor e la garantía de préstamos hipotecarios, lo que facilita el acceso de financiación de los posibles compradores (Alfonso, Kovner \& Schoar, 2010). En este sentido, conviene resaltar que la intervención de las GSE mencionadas está contribuyendo en buena medida al funcionamiento del mercado de titulización de hipotecas. 
- Otro de los factores determinantes en la mejora de las condiciones hipotecarias ha sido la compra de activos respaldados por hipotecas (MBS) del Tesoro y de la Reserva Federal (por un importe total de 1.45 billones de dólares), y las compras de deuda de agencia realizadas por la Reserva Federal (por 175 mm de dólares) (Alfonso, Kovner \& Schoar, 2010). Mientras que las primeras redujeron directamente los tipos de interés hipotecarios, las segundas lo hicieron de manera indirecta, reduciendo el coste de financiación de las agencias, lo que permitía, entre otros, un mayor volumen de compras para su propia cartera y, por tanto, mayor demanda de MBS, mayor precio y menor tipo de interés asociado.

- En tercer lugar, se reactivaron créditos fiscales para la adquisición de vivienda, que probaron ser determinantes en la evolución de la recuperación del mercado. Así, inicialmente, la retirada de estas ayudas- prevista para final de octubre- causó un importante retroceso en el mercado de la vivienda, lo que generó incertidumbre sobre la solidez de su recuperación y motivó la extensión de estas ayudas hasta fin de abril de 2010, favoreciendo un repunte de las ventas en el mes de marzo.

El segundo grupo de medidas, dirigidas a prevenir ejecuciones evitables y a estabilizar aéreas particularmente afectadas, se concreta:

- Programa de modificación de hipotecas en dificultades, que podría afectar entre 3 y 4 millones de hipotecas hasta 2012. Hasta abril de 2010, las entidades habían ofrecido 1.5 millones y solo 300.000 tienen ya el carácter permanente (las demás se mantiene en periodo de prueba). El ahorro medio 
mensual es de 500 dólares por hipoteca y la mediana de la ratio de deuda sobre renta en este grupo de prestatarios se ha reducido del $80.2 \%$ al $44.9 \%$. (Alfonso, Kovner \& Schoar, 2010).

- Programa de refinanciación de hipotecas: el cambio de las condiciones del mercado hipotecario causó que muchos tenedores de hipotecas estuvieran pagando condiciones excesivas, dada la nueva situación. El programa de refinanciación de hipoteca hasta abril de 2010 ha cambiado las condiciones de 4 millones de hipotecas, con una reducción media de la cuota mensual de 150 dólares. (Alfonso, Kovner \& Schoar, 2010).

- En tercer lugar, y aunque no hay cifras de impacto, se activaron medidas para la estabilización del mercado en áreas particularmente afectadas por un elevado número de hipotecas ejecutadas. Tanto la dotación como el impacto de esta medida son reducidos en relación con las demás acciones. (Alfonso, Kovner \& Schoar, 2010). 


\section{ASPECTOS RELEVANTES DE LA CRISIS HIPOTECARIA EN ESPAÑA}

Para nadie es un secreto que para hablar de la crisis hipotecaria en España, lo primero que hay que hacer es distinguir entre la crisis financiera global y la crisis inmobiliaria, pues, los mercados financieros hoy en día son globales, mientras que las crisis inmobiliarias corresponden a cada país, los factores que la determinan son diferentes y por ende las soluciones igualmente diferentes, aunque puede que coincidan unas con otras.

La crisis económica de España, es producto del marco de globalización económica iniciada en Norteamérica y que fue desencadenada, primero, por la desaceleración económica del país, segundo la apreciación fuerte del euro frente al dólar y tercero, la subida rápida de intereses. Por otro lado, la política económica central que controla la inflación y que es dirigida por el presidente del Banco Central Europeo (Jean Claude Trichet), no está en línea con los intereses ni la situación económica de España, generando de ésta forma aumento de los tipos de interés, al igual que la obtención de financiación de préstamos con tasas de interés variables y la reducción del ahorro por el aumento del nivel de endeudamiento. (Bruno Saravia Rupérez, 2008).

Ahora veamos, de manera general, algunos apartes de lo que escribió Bruno Sarabia Rupérez, en un artículo que sobre la crisis hipotecaria española escribió en la revista Tribuna de mayo de 2.008: 
Si se hace un análisis más detallado del mercado inmobiliario, descubrimos que es un sector que desde hacia tiempo daba signos de estar en lo más álgido de su curva de crecimiento, donde continuamente se hablaba de la explosión de la "burbuja inmobiliaria" y del excesivo incremento en los precios de las viviendas. El ritmo de crecimiento de este sector no correspondía con la cantidad real demandada ni con los precios que esta demanda podría soportar en el país y que, como se ha podido observar, han llegado a multiplicarse su valor en los últimos años. A estos factores mencionados hay que añadir el periodo de bonanza económica donde las entidades financieras han sido muy generosas en la concesión de todo tipo de financiación, tanto a particulares como a empresas. Este marco que se deja entrever, hace muy atractivo el endeudamiento, respondiendo la sociedad con la compra de inmuebles, incluso por encima de las posibilidades reales, colaborando en el incremento de los índices de consumo y endeudamiento del país a niveles desconocidos hasta la fecha.

Es todo este maremágnum de condicionantes lo que ha permitido gestar la tan temida crisis hipotecaria. Entidades financieras que abren sus puertas a la concesión de créditos tremendamente atractivos para un público incauto y poco conocedor de los mercados financieros y su funcionamiento, normalmente a un tipo de interés variable que repercute en una cuotas que navegan al son del Euribor (índice de referencia que determina el precio de intercambio del dinero entre las entidades financieras) y que van en beneficio de los prestamistas. Ofertas de créditos hipotecarios con carencia a particulares en donde no se advierte de las consecuencias negativas que tienen para ellos y 
que son, sin embargo, perfectamente indicados para otros tipos de créditos financieros, sobre todo dirigidos a empresas.

Esta situación afecta tanto a particulares y empresas, donde un exceso de liquidez en los mercados se acompaña de un mayor consumo y, por desgracia, en los tiempos que corren, también de un menor ahorro, como se pueden ver en los últimos datos de endeudamiento que se cifran en torno al doble de la renta per cápita percibida.

Si nos referimos al sector de particulares, esta crisis finalmente se traduce en un incremento elevado en la renta destinada a financiar la compra de su vivienda, destacando aquellas hipotecas que se han firmado en los últimos años que, como comentábamos anteriormente, se han firmado con períodos de carencia entre uno y dos años, lo que se traduce en la nula reducción del capital pendiente de las mismas y en duplicar los intereses a pagar (se ha pasado de tipos del 2,25\% al $4,95 \%$ en apenas dos años), lo que finalmente se traduce en cuotas apenas soportables para la mayoría de las familias.

En cuanto al caso particular de las empresas, se puede decir que la crisis les afecta en mayor medida y por partida doble. Por un lado, las empresas requieren de mayor financiación para mantener sus volúmenes de crecimiento a unos precios cada vez más altos. Por otro, deben ver reducidos sus ingresos dado el menor consumo, lo que en numerosos casos se ha traducido en la insostenibilidad económica de la firma, teniendo que llevar a cabo reducciones de plantilla y finalmente presentarse al procedimiento concursal, anteriormente conocido como suspensión de pagos. 
Este hecho es particularmente grave ya que se crea una espiral de reducción de consumo y, por tanto, de actividad industrial y comercial que sólo puede pararse con una política económica adecuada marcada desde las Entidades Públicas correspondientes.

Ahora bien, vale la pena aclarar que la crisis hipotecaria de España, no se debe a la crisis hipotecaria de EEUU, si bien es cierto la crisis económica norteamericana golpea los países de una u otra forma en sentido financiero, no es menos cierto que cada país sufre su propia crisis hipotecaria por causas internas y que a continuación podremos ilustrar.

Para efectos de complementar el estudio de éste capítulo, me parece importante revisar otros autores que analizaron la crisis hipotecaria Española. Es por ello, que revisaremos, lo que para el efecto escribió Gonzalo Bernardos Domínguez, en su artículo denominado "creación y destrucción de la burbuja inmobiliaria en España", quien determina de forma clara, cuales fueron las causas de la crisis hipotecaria en dicho país, descartando en su escrito, que las causas de la crisis hipotecaria de España fueran generadas directamente por las conocidísimas hipotecas "Subprime", - que generaron la crisis de EEUU -, pero reconociendo que sí existió un efecto indirecto, pero en el sentido que provocó restricciónes para encontrar financiación extranjera por parte de cajas y bancos españoles. En consecuencia de lo anterior, procederé a identificar del mismo texto, las principales causas. 
Como primera causa, podemos decir que en el periodo comprendido entre 1.998 y el año 2005, debido a que los bancos tenían bastante liquidez, por cuanto había una gran expansión de las cajas de ahorros, una enorme competencia bancaria y unos tipos de interés muy reducidos; proporcionó abundantes créditos a adquirentes y promotores de vivienda, contribuyendo a niveles record, el aumento de la oferta y demanda de las residencias. Esta expansión de las cajas tenían como objetivo expandirse territorialmente a tal punto de diversificar geográficamente el negocio bancario, y posesionarse en dichos lugares teniendo una alta rentabilidad, pero para ello, había que financiar a los promotores de vivienda en sus proyectos, para lograr posteriormente la subrogación hipotecaria de las familias como principal instrumento de captación de clientela. Esta agresividad de las cajas de ahorro hicieron que los bancos compitieran a la par, generando facilidades excesivas para la compra de las viviendas.

En segundo lugar, vemos que la elevada demanda de viviendas provocaba un incremento de viviendas construidas, incentivando la compra de éstas por parte de los ciudadanos españoles e inmigrantes, enfocados a que el gran incremento del precio de la vivienda generaba grandes plusvalías, dando la posibilidad de acceder a una mayor financiación bancaria. Situación que no importaba por cuanto la liquidez existente en la economía mundial permitía financiar el excesivo gasto del sector privado a unas tasas de interés bajas. En el año 1.998 se habló del boom inmobiliario en España. Entre 1998 y el 2005 se multiplico por 6 el número de inmigrantes que llegaron a trabajar y quienes fueron actores activos en la adquisición de vivienda, eso 
sí, primero las rentaban o alquilaban y luego se convertían en propietarios, ya que con la estabilidad de sus empleos, los bancos les financiaban la compra a tasas mínimas de interés.

Por último, en el año 2006, llega la recesión por efectos indirectos de la crisis hipotecaria de EEUU. En consecuencia de lo anterior, se empieza a reducir la capacidad para encontrar financiación extranjera por parte de cajas y bancos, provocando que estos endurecieran los criterios para la concesión de préstamos generando lo siguiente: primero, un alto nivel de reducción en la demanda, y un incremento en la oferta de viviendas o residencias, debido a la escasa disponibilidad de fondos de los demandantes derivado del desempleo; segundo, la restricción del crédito a familias y empresas; y tercero, los problemas de solvencia de las cajas y la iliquidez de los bancos. Lo anterior, generó un gran stock de viviendas pendientes de venta que fuera producido como consecuencia de un desfasado modelo de crecimiento, incapaz de sostener el nivel de ocupación alcanzado. Vale la pena aclarar, que los intermediarios inmobiliarios que vieron la compra de viviendas para comercializarlas en mayor valor, como gran negocio, ahora no tenían como venderlas, debiendo abandonar su actividad comercial por falta de rentabilidad, a tal punto que algunos de ellos entraron a concurso de acreedores. (Bernardos G 2006, 2007, 2008; Ocde 2005; Shiller R 2009). 


\section{ANALISIS COMPARATIVO DE LAS DIFERENTES CRISIS.}

Teniendo en cuenta que en el transcurso de la investigación se ha hecho alusión a la crisis hipotecaria Colombiana, de EEUU y España, me parece importante resaltar algunas diferencias y semejanzas que causaron la crisis en cada uno de estos países.

Empecemos por nuestro país, y para ello lo primero que habrá que decirse, es que las causas de la crisis hipotecaria colombiana son totalmente diferentes a la de EEUU y España. La crisis colombiana no se debió a un problema financiero mundial, ni a un impacto global económico y mucho menos a un coletazo de alguna crisis financiera o hipotecaria en otros países; en este mismo sentido, tampoco se debió una crisis financiera colombiana, a pesar de que la impresión para muchos, es que siempre hemos estado en crisis financiera. En éste orden de ideas, la crisis hipotecaria de nuestro país fue generada a partir de una decisión gubernamental en el año 1993, al ordenar el cambio de corrección monetaria que se encontraba atada al sistema de financiación de vivienda y que correspondía al IPC (índice de precios al consumidor), para ser reemplazado por una nueva unidad de corrección denominada DTF (depósito a término fijo). Al efectuar este cambio y partiendo de la base de que la DTF con el tiempo fue más alta que el IPC, las deudas hipotecarias se dispararon, generando el impago de las obligaciones de los deudores hipotecarios. Vale la pena resaltar que a diferencia de otros países y como lo dije anteriormente, la crisis hipotecaria nunca llegó como efecto de alguna crisis financiera interna o externa, 
pero ésta crisis si hubiera podido haber generado una crisis financiera en Colombia. Lo anterior, se pudo visualizar por el impacto generado en el sector bancario y empresarial, a tal punto que los bancos implementaron formas de ayudar a los deudores hipotecarios y empresariales, como por ejemplo: reducción de tasas, ampliación de plazos, refinanciación de obligaciones, sugerir daciones en pago y finalmente solicitar ayuda del gobierno para que a través de sus órganos estatales concediera préstamos a los deudores para poner al día sus obligaciones. Todo lo anterior, hasta que en el año 1.999, el estado a través de la judicatura ordenó la creación de una ley de vivienda, - Colombia no tenía ley de vivienda -, que garantizara el derecho a la vivienda digna. Por otro lado, y teniendo en cuenta que el sector empresarial se sintió afectado también por el no cumplimiento de sus obligaciones bancarias, laborales y fiscales, se crearon legislaciones tendientes a el salvamento de la aquellas como por ejemplo la ley 222 de 1.995 concordatos y liquidación obligatoria, y la ley 550 de 1.999 reestructuración empresarial.

En EEUU, vemos que las causas son totalmente diferentes, pues, a pesar de que la crisis hipotecaria tampoco provino de un problema global financiero o de un coletazo financiero mundial o hipotecario de otros países, si se generó por situaciones particulares especiales derivadas por la falta de control en el otorgamiento de los préstamos para adquisición de vivienda. Es por ello que surgen las conocidas hipotecas de alto riesgo "Subprime" que fueron orientadas como política institucional a los clientes de bajos recursos y carentes de solvencia económica, las cuales generaban un alto riesgo de impago, a diferencia de las otras clases de hipotecas. Estas hipotecas se caracterizaban adicionalmente porque se 
concedían con tasas promocionales, pero después subían poniéndose más costosas que las de los créditos personales, pues, los bancos norteamericanos tenían unos límites para esta clase de préstamo que fueron impuestos por la reserva federal. Es evidente que la motivación de los bancos para hacer estas hipotecas, se basaba en que éstas podían ser objeto de ventas a inversores, eso sí, asumiendo estos los riesgos de los posibles impagos o disminución de las garantías, que debido a la gran velocidad como se hacen estas transacciones, en muchos casos no es posible darse cuenta del riesgo asumido. Todo lo anterior desencadena en la crisis hipotecaria en el año 2007, cuando los inversores se vieron en riesgo y veían venir el no pago de las hipotecas por parte de los deudores, debido a que las tasas de interés habían subido al igual que las cuotas hipotecarias a cancelar. En consecuencia de lo anterior, efectivamente, los deudores no pagan, entran en mora y los bancos comienzas a ejecutar las hipotecas. Lo anterior supone una política de reducción de crédito por parte de los bancos, pánico de los inversores y caída de la bolsa de valores por falta de liquidez.

Finalmente, si revisamos lo que pasó en España, nos damos cuenta que las causas también son diferentes: Al principio, los bancos y cajas de ahorro tenían bastante liquidez, - debido a que la economía mundial permitía financiar el excesivo gasto del sector privado a unas tasas de interés muy bajas-, generando una enorme competencia bancaria a unos tipos de interés muy reducidos. Lo anterior generó el otorgamiento de abundantes créditos a adquirentes y promotores de vivienda, contribuyendo a niveles record, el aumento de la oferta y demanda de las residencias. Esto generó, que habiendo facilidades para la compra de vivienda, se 
convirtiera en un excelente negocio para promotores e intermediarios inmobiliarios, pues se compraban las viviendas para ser vendidas a precios muy elevados. A diferencia de EEUU y Colombia, en España desempeño un papel muy importante los inmigrantes que llegaron y que por obvias razones terminaban comprando residencias a precios que podían pagar debido a su excelente estabilidad económica.

Todo lo anterior genera que en el año 2006, y por culpa de la recesión ocasionada indirectamente por la crisis hipotecaria de EEUU, los inmigrantes empiezan a perder sus empleos y dejan de cancelar sus obligaciones, se aumentan las tasas de interés de los créditos, se empieza a reducir la capacidad para encontrar financiación extranjera por parte de cajas y bancos. Lo anterior provoca que los bancos y cajas los criterios para la concesión de préstamos generando un alto nivel de reducción en la demanda, y un incremento en la oferta de viviendas o residencias.

Espero que con esta pequeña ilustración, sea suficiente para que el lector se de una idea de las causas y consecuencias de las crisis hipotecarias en los países señalados. 


\section{CAUSAS QUE DIERON ORIGEN AL DEBATE JURISPRUDENCIAL EN COLOMBIA EN CUANTO AL PARAGRAFO 3 DEL ARTÍCULO 42 DE LA LEY 546/99}

Es muy importante que previo a ilustrar el problema suscitado con el parágrafo 3 del artículo 42 de la ley 546 de 1.999, y sus opuestas interpretaciones, revisemos rápidamente las causas que generaron el debate jurisprudencial. Para el efecto, podemos concluir que la primera causa, surge a raíz del mal entendimiento de los conceptos de "reliquidación de los créditos de vivienda" V/s "reestructuración de los créditos de vivienda, pues las interpretaciones contrapuestas, efectuadas por los operadores judiciales que conocieron de este tema específicamente, son producto de la interpretación acomodada de lo que quería decirse con la palabra "Reliquidación", a tal punto de confundirse en algunos eventos con la palabra "Reestructuración".

La segunda causa se manifiesta expresamente en el contenido del fallo proferido por la Corte Constitucional C-955 del año 2.000, donde declaró inconstitucional algunos apartes del texto original del parágrafo 3 del artículo 42 de la ley de vivienda y que miraremos más adelante.

Fundamental es entonces, proceder a explicar cada una de las causas empezando primero por diferenciar los conceptos de "reliquidación" y "reestructuración", así como de gran importancia revisar como fue concebido legalmente la aplicación de dichos conceptos.

El Doctor Hernán Fabio López Blanco en su libro la ley de vivienda (546 de 1.999) y sus implicaciones en el campo procesal civil dice: 
...7.1. Es necesario tener claramente delimitados el alcance de los conceptos de "reliquidación" y de "reestructuración" predicados de los créditos para vivienda individual, pues únicamente su cabal entendimiento permite solucionar dudas que surgen de la aplicación inadecuada que de ellos se hace, incluso en la misma ley 546 de 1.999 , donde en veces se les utiliza como si fueran sinónimos, que no lo son... (p. 49)

Precisamente y para efectos de distinguir los dos conceptos éste mismo autor hace una diferenciación en la misma obra, manifestando:

En suma se entiende por reliquidación el abono que imperiosamente se debe hacer a un crédito de vivienda individual o a varios pero respecto del mismo inmueble, sobre las bases señaladas en los artículos 40 y 41 de la ley 546 de 1.999, operación que no implica alteración diversa a la rebaja del saldo que determina el abono y que se hace por una sola vez; la reestructuración del crédito es el acuerdo al que voluntariamente llegan deudor y entidad financiera, donde se pueden modificar aspectos tales como tasas de interés, plazo para pagar o sistema de amortización y podrá ser efectuada las veces que las partes así lo quieran . (p.17)

Teniendo en cuenta que los artículos 40 y 41 de la ley 546 de 1.999, establecían la forma como debía reliquidarse los créditos, utilizaremos para explicarlo, lo que muy claramente expuso al respecto en la Guía práctica del crédito de vivienda en UVR (2002): 
La denominada "reliquidación", como su nombre lo indica, consistió en liquidar nuevamente los créditos de vivienda que habían sido otorgados en UPAC o en pesos con tasa referida al DTF y que se encontraban vigentes al 31 de diciembre de 1.999, tomando como base la UVR. Para tales efectos se utilizó la UVR establecida mediante la resolución 2896 de 1.999 del ministerio de Hacienda y Crédito Público, para cada uno de los días comprendidos entre el $1^{\circ}$ de Enero de 1.993 y el 31 de diciembre de 1.999 .

El saldo en pesos reliquidado que al 31 de diciembre de 1.999, utilizando la UVR, se comparó con el saldo en pesos que presentaban a esa misma fecha los créditos otorgados en UPAC o en pesos. En los casos en que éste último fue superior al primero, se realizó un abono al crédito equivalente a la diferencia entre ambos (ley 546/99, arts. 41 y 42; Superbancaria, Circ. Externa 7 de 2000)“. "Las bases de la metodología para efectuar la reliquidación, fueron dadas por la misma ley de vivienda y posteriormente la Superintendencia Bancaria, como entidad gubernamental encargada de la vigilancia y control de las entidades financieras que debían efectuar la reliquidación, impartió instrucciones específicas al respecto mediante circular 007 del 27 de enero de 2000 y sus circulares modificatorias.

De esta manera sólo existió un procedimiento para efectuar la reliquidación, que debió ser observado por todas las entidades financieras que habían otorgado créditos de vivienda. Correspondió a la superintendencia Bancaria la revisión de todas las reliquidaciones efectuadas por los establecimientos de crédito en virtud de la facultad de control y vigilancia que ejerce la entidad. (Ley 546/99, art.41) (p.32, 33) 
De lo anterior, podemos deducir que sólo se reliquidaban deudas desde 1.993 hasta 1.999, independientemente el crédito hubiere sido creado con anterioridad al año 93. Una vez se reliquidara el crédito podía o no obtenerse un alivio, el cual al aplicarse a la obligación podía quedar al día o no. De acuerdo a esto, es que algunos jueces y magistrados interpretaban, que si al aplicar el alivio la obligación quedaba al día, debía terminarse el proceso, de lo contrario, debería continuar el mismo ya que no tenía sentido terminarlo para volverlo a empezar, pues atentaría contra el principio de economía procesal; otros, interpretaban que con el simple hecho de que se re liquidaran las obligaciones y una vez aplicado el alivio, el crédito quedara o no al día, debía terminarse.

La segunda causa, corresponde al contenido de la sentencia C-955 del 26 de julio de 2000, donde la Corte Constitucional declaró inexequibles algunos apartes del parágrafo en comento, pronunciamiento que marcó el inicio de las interpretaciones contrapuestas respecto de la continuación o terminación de los procesos ejecutivos hipotecarios iniciados con anterioridad a 1999.

Veamos el texto original del parágrafo 3o del artículo 42 de la ley 546 de 1.999, como fue concebido originalmente:

\section{ARTÍCULO 42. ABONO A LOS CRÉDITOS QUE SE ENCUENTREN EN MORA.}

PARÁGRAFO 3o. Los deudores cuyas obligaciones se encuentren vencidas y sobre las cuales recaigan procesos judiciales que dentro de los noventa (90) días siguientes a la entrada en vigencia de la presente ley decidan acogerse a la reliquidación de su crédito hipotecario, tendrán derecho 
a solicitar suspensión de los mencionados procesos. Dicha suspensión podrá otorgarse automáticamente por el juez respectivo.

En caso de que el deudor acuerde (dentro del plazo) la reliquidación de su obligación, de conformidad con lo previsto en éste artículo el proceso se dará por terminado y se procederá a su archivo sin más trámite. Si dentro del año siguiente a la reestructuración del crédito el deudor incurre nuevamente en mora, los procesos se reiniciarán a solicitud de la entidad financiera y con la sola demostración de la mora en la etapa en que se encontraban al momento de la suspensión, y previa actualización de su cuantía.

Ahora, veamos el texto declarado exequible por la Corte Constitucional:

\section{ARTíCULO 42. ABONO A LOS CRÉDITOS QUE SE ENCUENTREN EN MORA.}

PARÁGRAFO 3o. Los deudores cuyas obligaciones se encuentren vencidas y sobre las cuales recaigan procesos judiciales, tendrán derecho a solicitar suspensión de los mencionados procesos. Dicha suspensión podrá otorgarse automáticamente por el juez respectivo. En caso de que el deudor acuerde la reliquidación de su obligación, de conformidad con lo previsto en éste artículo el proceso se dará por terminado y se procederá a su archivo sin más trámite.

El plazo de noventa (90) días siguientes a la entrada en vigencia de la ley, para que los deudores solicitaran la reliquidación de su crédito hipotecario y ello diera 
lugar a la suspensión de los procesos, fue declarado inexequible porque la reliquidación del crédito era un derecho de todos los deudores del sistema UPAC, por lo tanto era un requisito que rompía la igualdad e injustificadamente condenaba a una persona, a no recibir oportunamente el abono que le correspondía, a no poder efectuar la compensación entre el abono y el saldo de su deuda, y muy probablemente a ser condenada en el proceso.

De manera que, si la reliquidación era un derecho de todos aquellos que estuvieran en deuda con el sistema, queda sin ninguna justificación cualquier plazo perentorio para acogerse o no a la reliquidación, o para gozar los beneficios de ésta, como es la suspensión y posterior terminación del proceso en contra del deudor.

Por su parte, el inciso final del parágrafo bajo estudio fue declarado inexequible porque estipulaba que si dentro del año siguiente el deudor incurre nuevamente en mora, los procesos podrían reiniciarse en la etapa que se encontraban al momento que operó la suspensión, previa actualización de su cuantía, con la sola demostración de la mora y la solicitud de la entidad financiera.

Al respecto la Corte manifestó, que esta disposición contravenía los derechos a la igualdad, al debido proceso y a la administración de justicia, por cuanto situaciones jurídicas distintas estaban siendo tratadas de manera idéntica, ya que si el deudor reincide en la mora, lo que debe hacerse es iniciar un nuevo proceso y no acumularlo a otro que por mandato legal ya había terminado.

Siendo así las cosas, el debate académico y jurisprudencial del texto corregido en virtud del control constitucional tiene dos implicaciones: la primera, parte del contenido inicial del parágrafo 3 del artículo 42 de la ley 546 de 1.999 que dice: "Los deudores cuyas obligaciones se encuentren vencidas y sobre las cuales recaigan 
procesos judiciales, tendrán derecho a solicitar suspensión de los mencionados procesos. Dicha suspensión podrá otorgarse automáticamente por el juez respectivo."

Esto clarifica simplemente que ya sea a solicitud de parte o de oficio por el juez es viable suspender los procesos judiciales. Esto obviamente hay que interpretarlo en el entendido de que se suspenderán los procesos, sólo si se logra demostrar que no se ha hecho la reliquidación del crédito por parte de la institución financiera y en consecuencia mientras se efectúa el juez podrá suspenderlo. Hasta aquí, aparentemente, pudiéramos pensar que tan sólo se está hablando de la figura de la suspensión y quien puede promoverla, pero esto no es así.

Efectivamente, el análisis hecho por la Corte Constitucional iba enfocado a que si se suspendían los procesos era para efectuarse la reliquidación del crédito y el hecho de hacer la reliquidación implicaba que debía terminarse el proceso y archivarse sin más trámite. Veamos, lo expuesto por Hernán Fabio López Blanco (1999), cuando analiza la sentencia C-955 de 2.000:

La Corte Constitucional en sentencia C-955 del 2.000 en donde se cuida de advertir que "La parte motiva de esta providencia se encuentra indisolublemente vinculada a la resolutiva y por tanto, es obligatoria" de manera que no se puede desconocer que en la citada sentencia y respecto del punto que interesa, expresó la corte lo siguiente: "Agrega la norma que dicha suspensión podrá otorgarse automáticamente por el juez respectivo, lo cual significa que no necesariamente es indispensable la solicitud por parte del interesado" (Folio 165) y, adelante expresa: "En este orden de ideas, la 
suspensión de los procesos en curso, ya por petición del deudor, o por decisión adoptada de oficio por el juez, tiene por objeto que se efectúe la reliquidación del crédito y, producida ella, debe dar lugar a la terminación del proceso y a su archivo sin más trámite como lo ordena la norma... (Folio 166).

La segunda implicación recae en el contenido final de la norma en comento que dice: “En caso de que el deudor acuerde la reliquidación de su obligación, de conformidad con lo previsto en éste artículo el proceso se dará por terminado y se procederá a su archivo sin más trámite “. (Artículo 42 de la Ley 546- 1999) (Subrayado fuera del texto).

En este estado, nos gustaría plantear lo siguiente: cuando se diferenció el término conceptual de "reliquidación” y "reestructuración” se estableció que ésta, tenia como requisito fundamental el acuerdo entre el deudor y la entidad financiera para normalizar la mora de la obligación, mientras que aquella, se hacia para todos los créditos vigentes a 31 de Diciembre de 1.999 y por mandato legal.

Entonces, ¿que quiso decir la corte cuando dice: “... En caso de que el deudor acuerde la reliquidación de su obligación ..." ?. Será que se está refiriendo a la reestructuración, que es la que se acuerda entre deudor y acreedor y que como producto de este acuerdo entre las partes es viable al tenor de la norma terminar el proceso?; o será que la palabra "acuerdo" es palabra muerta y no tiene ingerencia alguna en la norma y entonces debemos interpretar que, ¿siempre que deba hacerse reliquidación, - o sea en todos los casos de vivienda y que se encuentren vigentes al 31 de Diciembre de 1.999, - se deben terminar los procesos independientemente con 
esta queden al día o no las obligaciones, de conformidad con lo expresado por la Corte Constitucional?

Pues bien, estas fueron las causas que generaron los diferentes criterios de interpretación por parte de los operadores judiciales. En consecuencia procederemos a enunciar las decisiones más trascendentales y controvertidas, que deja en evidencia la problemática planteada. 
DESCRIPCIÓN Y ANÁLISIS JURISPRUDENCIAL SOBRE ALGUNAS DECISIONES CONTRAPUESTAS AL INTERPRETAR EL PARÁGRAFO 3 DEL ARTÍCULO 42 DE

\section{LA LEY 546 DE 1.999}

CORTE CONSTITUCIONAL, Sala Plena. Sentencia C - 955 de julio 26 de 2000, Magistrado Ponente: José Gregorio Hernández Galindo

Si un usuario del sistema de financiamiento de vivienda, no había terminado de pagar su deuda, tenía derecho a la reliquidación de su crédito, sin importar si se hallaba al día con su obligación aunque sin haber cancelado la totalidad de la deuda, o si se encontraba en mora y con la deuda vencida en virtud de la cláusula aceleratoria.

De manera que, si la reliquidación era un derecho de todos aquellos que estuvieran en deuda con el sistema, queda sin ninguna justificación cualquier plazo perentorio para acogerse 0 no a la reliquidación, o para gozar los beneficios de ésta, como es la suspensión del proceso en contra del deudor. De igual forma una vez efectuada la reliquidación del crédito debe dar lugar a la terminación del proceso y a su archivo sin más trámite.

El acreedor goza, por supuesto, del derecho a iniciar un nuevo proceso ejecutivo en contra de su deudor, pero mal puede retomarse el proceso expirado en la etapa en que se encontraba cuando se produjo la suspensión, puesto que ello significa atribuir efectos ultra activos a situaciones previas ya definidas, combinándolas con hechos nuevos en 
contra de una de las partes, con notorio desequilibrio en la relación procesal.

Este fallo sostiene, que efectivamente con el simple hecho de haberse reliquidado los créditos, debía terminarse el procesos o procesos ejecutivos hipotecarios que se hubieren iniciado antes del 31 de diciembre de 1.999. Adicionalmente, aclara que cuando se inicien nuevamente los procesos no debían iniciarse en la etapa que se encontraba cuando terminaron, si no que debía iniciarse de cero nuevamente. La aclaración me parece que sobra, pues nuestra legislación procesal no permite que se puedan iniciar acciones, saltándose etapas del procedimiento respectivo, pues de pensar así, se vulneraría el derecho al debido proceso, a manera de ejemplo, ¿Qué pasaría en el evento de que se terminara el proceso en etapa de alegatos de conclusión, cuando en el debate probatorio se practicaron pruebas donde se resuelven saldos de la obligación que ya no corresponden a la realidad y que el deudor manifiesta no estar de acuerdo?. La verdad no tendría sentido, pues debería, entre otras decretar y practicar nuevas pruebas. Sin embargo, pues si la corte lo quiso aclarar para cerrar debates que pudieran llegar a presentarse sin sentido, me parece que es aceptable.

CORTE CONSTITUCIONAL. Sentencia T-511 de mayo 17 de 2001. Expediente T403443. Magistrado Ponente. Eduardo Montealegre Lynett.

Observa la sala que, dentro del proceso ejecutivo adelantado por DAVIVIENDA en contra del señor Gaviria Otálora, la actuación del Juzgado, lejos de configurar una vía de hecho se ajusta plenamente a las 
exigencias del ordenamiento y de la jurisprudencia constitucional sobre la materia. En primer lugar, destaca la corte que dentro del proceso ejecutivo el juzgado exigió acreditar el cumplimiento de lo previsto en la ley 546 de 1.999, de conformidad con las sentencias C-383 de 1999 y C-700 del mismo año; posteriormente, una vez efectuada la reliquidación del crédito, accedió a la petición elevada por el ahora demandante, en el sentido de decretar la suspensión del proceso. Sin embargo, como no hubo acuerdo con la entidad respecto del cumplimiento de la Obligación y el deudor continuó en mora, mal podría decretar la terminación del proceso por lo que, a solicitud de DAVIVIENDA y teniendo en cuenta que otros despachos judiciales habían embargado los remanentes, dispuso proseguir con la ejecución.

Igualmente cabe advertir que en todo momento estuvieron asegurados los derechos de contradicción y defensa; cosa distinta es que el demandado no hubiere recurrido a ellos para controvertir por ejemplo, la reliquidación del crédito o el auto que fijó la fecha para el remate. No puede pretender ahora en sede de tutela remediar las omisiones 0 negligencias en que eventualmente pudo haber ocurrido. Tampoco puede la corte avalar este tipo de conductas que desnaturalizan los elementos de residualidad y subsidiariedad de las acciones de tutela. En estos términos no existiendo vulneración de derechos fundamentales, las decisiones de instancia habrá que ser confirmadas. 
Consideró la Corte, que de la jurisprudencia constitucional sobre reliquidación de créditos hipotecarios (Ley 546 de 1999) pueden derivarse tres argumentos centrales:

a) La Corporación reconoció que toda persona contra quien se siguiera un proceso judicial por la mora en el pago de obligaciones crediticias tenía derecho a que se decretara la suspensión de los procesos, aún de oficio; recordemos que en éste sentido la Corte Constitucional ya se había pronunciado mediante sentencia C-955 de 2.000 manifestando que la suspensión de los procesos en curso se podía dar por petición del deudor, o por decisión adoptada de oficio por el juez.

b) Si el deudor y la entidad financiera acordaban la reliquidación de la obligación, debía decretarse la terminación del proceso y su archivo sin más trámite; recordemos que el sentido que inicial que le daba la corte ha este postulado y en nuestro sentir, era el de un acuerdo entre acreedor y deudor respecto de la obligación, que culminaba con una reestructuración (no reliquidación), pero cuando no se culminaba con la firma del acuerdo y el deudor continuaba en mora, no era procedente terminar el proceso.

c) Si dentro del año siguiente a la reestructuración del crédito acordado con la entidad, el deudor volviere a incurrir en mora, debería iniciarse un nuevo proceso judicial y no podría reanudarse el primero por tratarse de situaciones jurídicas distintas.

d) Sin embargo es necesario que el deudor haya actuado en las diferentes instancias del proceso, controvirtiendo por ejemplo la reliquidación 
de su crédito, y no puede pretender ahora, en sede de tutela, remediar las omisiones o negligencias en que eventualmente pudo haber incurrido.

Dos cosas importantes de resaltar: la primera, si nos damos cuenta la corte a través de éste fallo dejó entrever que el acuerdo de reliquidación debía interpretarse como "reestructuración", es decir, que el deudor llegara a un acuerdo voluntario con la entidad sobre saldos y políticas nuevas del crédito hipotecario, y no en el entendido de acuerdo de reliquidación como "reliquidación por ley", que se hacía automáticamente a todas las obligaciones vigentes a 31 de diciembre de 1.999 con la finalidad de obtener el alivio respectivo. La segunda, que precisamente y sin pensar que pasaría en el futuro, pues, hasta ahora llevaba un año de vigencia la ley de vivienda, la mayoría de sus criterios, como por ejemplo, que quien reclame haya ejercido los derechos de contradicción y defensa dentro del transcurso del proceso, los cuales serían acogidos en el año 2007 por ésta misma corporación en la sentencia de unificación SU-813 del 4 de octubre, la cual resolvería de una vez por todas la discusión que hasta ahora empezaba a vislumbrarse.

CORTE CONSTITUCIONAL. T-606 de 2003, MP Álvaro Tafúr Galvis ...la finalización de los procesos en curso, en los términos del parágrafo 3 del artículo 42 de la ley 546 de 1999, es una modalidad especial en cuanto da lugar a la terminación de los procesos sin efectos de cosa Juzgada material y sin novar la obligación, por disposición expresa de la ley. (...). En suma una vez concluido el trámite de la reliquidación del crédito, los procesos iniciados antes del 31 de diciembre de 1.999, 
iniciados para hacer efectivas obligaciones hipotecarias convenidas en UPAC, terminaron por ministerio de la ley, pero una vez adecuados los documentos contentivos de la obligación dichos procesos pudieron haberse iniciado nuevamente, esta vez para solucionar créditos convenidos en UVR(s); si el deudor no convino en la reestructuración del crédito o incumplió la convenida a fin de satisfacer efectivamente el acreedor.

La Corte, además de reiterar su posición sobre la terminación de los procesos en virtud de haberse efectuado la reliquidación, aclara los efectos procesales de las terminaciones, advirtiendo que ellas no están revestidas de cosa juzgada material, a tal punto que los diferentes acreedores podrán iniciar nuevamente los procesos judiciales, pero con los saldos debidamente actualizados y en UVR.

La corte aclara, que la terminación de un proceso bajo estas circunstancias, no implica novación de la obligación y es precisamente por ésta razón que se puede volver a presentar la demanda de nuevo con el mismo pagaré creado en UPAC, pero advirtiendo que por ministerio de la ley deberá entenderse para todos sus efectos en UVR. Cosa diferente en el evento de que el deudor haya convenido la reestructuración del crédito, lo cual amerita la creación de un nuevo pagaré, con nuevas condiciones y pactado desde su comienzo en UVR; en tal sentido deberá por obvias razones iniciarse la demanda con el pagaré reestructurado.

CORTE CONSTITUCIONAL T - 701 de julio 29 de 2004. Magistrado Ponente: Rodrigo Uprimy Yepes 
En ese orden de ideas, la suspensión de los procesos en curso, ya por petición del deudor, o por decisión adoptada de oficio por el juez, tiene por objeto que se efectúe la reliquidación del crédito y, producida ella, debe dar lugar a la terminación del proceso y a su archivo sin más trámite, como lo ordena la norma, que en tal sentido, lejos de vulnerar, desarrolla el postulado constitucional que propende el establecimientos de un orden justo (Preámbulo y artículo 2 C.P.) y realiza los principios de prevalencia del derecho sustancial (art. 228 del C.P. ) y de acceso a la administración de justicia (art. 229 C.P.)

En efecto, dicha providencia señala expresamente como objeto de la suspensión de los procesos ejecutivos la realización de la reliquidación del crédito y, a su vez, la reliquidación de los créditos es señalada como condición necesaria y suficiente para la terminación.

La corte adicionalmente involucra en su decisión, máximas constitucionales consagradas en la Carta Magna, en el entendido de que las actuaciones de la administración de justicia son públicas y en estas debe prevalecer el derecho sustancial (Art. 228 del C.P.). Igualmente lo involucra con los fines del estado, cuales son entre otros: "Garantizar la efectividad de los principios, derechos y deberes consagrados en la constitución". (Art. 2 de la C.P.) justifica su decisión en que uno de los fines del estado es la garantía

CORTE CONSTITUCIONAL. Sentencia T-1061/05 20 de octubre de 2005 Magistrado Ponente Dr. ALFREDO BELTRÁN SIERRA. Referencia: expedientes T-1180244 
En recientes pronunciamientos esta Corporación, sobre el tema objeto de estudio ha dicho: en la sentencia T-692 de 2005, M.P. Jaime Córdoba Triviño, se refirió a esta situación en los siguientes términos: "En efecto, desde la sentencia C-955 de 26 de julio de 2000, por medio de la cual se adelantó el control de constitucionalidad de la Ley 546 de 1999, la Corte indicó que la condición para dar por terminados los procesos ejecutivos hipotecarios en trámite a 31 de diciembre de 1999 era la reliquidación de la deuda. En este sentido no distinguió la hipótesis en la cual, luego de la liquidación quedaren saldos insolutos o aquella según la cual las partes no pudieran llegar a un acuerdo respecto de la reestructuración del crédito".

De la misma manera, la sentencia T-391 de 2005 M.P Alfredo Beltrán Sierra, al tratar un asunto igual al que ahora se estudia señaló que: "Era deber del juez acusado, después de aportada la reliquidación del crédito, dar por terminado el proceso ejecutivo hipotecario, por ministerio de la ley, sin necesidad de entrar a establecer si dicha liquidación se ajustaba o no a la misma, ya que de existir algún saldo a favor de la entidad financiera éste debía cobrarse en otro proceso diferente al ejecutivo hipotecario en curso".

Posteriormente, la sentencia T-495 de 2005, M.P. Rodrigo Escobar Gil al estudiar un caso igual al que ahora ocupa a la Corte indicó que: "En el presente caso, considerando que el proceso ejecutivo se inició antes del 31 de diciembre de 1999, y que el mismo surtió su trámite con posterioridad al pronunciamiento de la Corte que definió con efecto de cosa juzgada constitucional el sentido del parágrafo $3^{\circ}$ del artículo 42 de la Ley 546 de 1999, fuerza es concluir que la autoridad judicial demandada, al dictar 
sentencia y seguir adelante con la ejecución, interpretó equivocadamente la norma en cita y desconoció el precedente jurisprudencial sobre la materia". Por último, se aclara que en esta providencia no será necesaria la elaboración de un profundo análisis de dicho artículo, toda vez que la posición adoptada por esta Corporación no ha variado.

En consecuencia de lo anterior, la Corte para resolver esta tutela, no incluye argumentos nuevos que sean objeto de comentario, por lo cual sustenta su decisión con base en la política que para el efecto la Corporación a ilustrado en reiteradas ocasiones.

CORTE CONSTITUCIONAL. Sala Primera de Revisión. Sentencia T - 258 de marzo 17 de 2005. Magistrado Ponente: JAIME ARAÚJO RENTERÍA

La corte manifiesta que habrá lugar a la protección del debido proceso y conexo a este la de todos los derechos constitucionales que resulten afectados. Cuando un juez de instancia continúa con las actuaciones judiciales, desconocen la doctrina constitucional reflejada en la sentencia C-955 de 2000 y otras proferidas por la corporación, citando precisamente la sentencia T - 606 de 2.003 donde advierte: "Una vez concluido el trámite de reliquidación del crédito, los procesos iniciados antes del 31 de diciembre de 1999, iniciados para hacer efectivas obligaciones hipotecarias convenidas en UPACS, terminaron por ministerio de la ley".

CORTE CONSTITUCIONAL. Sentencia T- 282 de 2005. Magistrado Ponente: Dr. RODRIGO ESCOBAR GIL, al respecto dijo: 
Por consiguiente, la posición jurisprudencial en esta materia considera que los procesos ejecutivos hipotecarios que se hubieren iniciado antes del 31 de diciembre de 1999 y que cumpliesen las condiciones para ser beneficiados con el alivio ofrecido en la Ley 546 de 1999 debieron: i) ser suspendidos mientras las entidades crediticias efectuaban la reliquidación del crédito, bien fuera por petición del deudor o de oficio; y ii) ser terminados y ordenado su archivo una vez efectuada la reliquidación.

Si una vez adecuado el título al nuevo sistema de UVR el deudor no se aviene a la reestructuración o incurre en mora, el acreedor puede iniciar un nuevo proceso ante la jurisdicción civil como juez natural de los conflictos suscitados con ocasión de la ley de vivienda. Esas discusiones deben ventilarse en otro proceso diferente del proceso ejecutivo que se encontraba en curso y que debió haberse terminado por ministerio de la ley.

Por el contrario, aquellas decisiones judiciales que ordenen continuar con el proceso alegando la ausencia de acuerdo entre el deudor y la entidad crediticia sobre la reestructuración del crédito, o la existencia de un saldo insoluto luego de aplicado el alivio, están fundadas en un entendimiento errado del citado artículo. Ello implica que las autoridades judiciales que decidan no dar por terminados esos procesos incurren en una vía de hecho por dos defectos sustantivos: por error en la interpretación del artículo 42 de la Ley 546 de 1999 y por desconocimiento del precedente judicial en la materia sentado por la Corte Constitucional. Pues la decisión judicial que se funda en una interpretación indebida de una norma jurídica que, por lo demás, ha sido reiteradamente aplicada por su interprete autorizado encargado de guiar a los 
operadores jurídicos con su doctrina constitucional integradora, conlleva una vía de hecho por defecto sustantivo o material.

Vale la pena resaltar, que la corte en este fallo tiene como particularidad, que basa su decisión en el conocimiento del precedente judicial que fuera argumentado en la sentencia T-701 de 2004, M.P. Rodrigo Uprimny Yepes, lo cual expone de la siguiente forma:

Precedente jurisprudencial respecto de la debida interpretación del parágrafo 3o del artículo 42 de la Ley 546 de 1999.

Como solución a la crisis social, económica y financiera provocada por el incremento desbordado de los créditos hipotecarios obtenidos para la financiación de vivienda a largo plazo y la imposibilidad de muchos deudores de pagar las cuotas correspondientes al superar su capacidad de pago, el legislador expidió la Ley 546 de 23 de diciembre de 1999 "por la cual se dictan normas en materia de vivienda, se señalan los objetivos y criterios generales a los cuales debe sujetarse el Gobierno Nacional para regular un sistema especializado para su financiación, se dictan medidas relacionadas con los impuestos y otros costos vinculados a la construcción y negociación de vivienda y se expiden otras disposiciones."

Su objetivo era crear un sistema especializado de financiación de vivienda a largo plazo que garantizara las condiciones necesarias para que la población colombiana acceda a una vivienda digna, según se indica en su artículo $2^{\circ}$. Para solucionar la gran cantidad de procesos ejecutivos en curso debido a la morosidad generalizada de los deudores, el legislador dispuso la 
aplicación de unos alivios que serían aplicados según el crédito estuviese al día o estuviese en mora a 31 de diciembre de 1999.

Como quiera que el caso objeto de revisión se encuadra dentro de esta última hipótesis, resulta relevante analizar el contenido del parágrafo $3^{\circ}$ del artículo 42 de la Ley 546 de 1999, disposición sobre la cual precisamente el Tribunal Superior de Pereira modificó su interpretación y que sustenta el cargo por la presunta vía de hecho que invoca la accionante.

Luego de haber sido estudiada su constitucionalidad por esta Corporación en la sentencia C-955 de 2000, el parágrafo del citado artículo 42 vigente en la actualidad es el siguiente:

"Artículo 42. Abono a los créditos que se encuentren en mora. Los deudores hipotecarios que estuvieren en mora al 31 de diciembre de 1999, podrán beneficiarse de los abonos previstos en el artículo 40, la entidad financiera procederá a condonar los intereses de mora y a reestructurar el crédito si fuere necesario.

A su turno, el Gobierno Nacional procederá a abonar a dichas obligaciones el monto total de la diferencia que arroje la reliquidación de la deuda, efectuada de conformidad con lo previsto en el numeral 2 del artículo 41 anterior, mediante la entrega al respectivo establecimiento de crédito de los títulos a que se refiere el parágrafo cuarto del mismo artículo 41.

Parágrafo 3. Los deudores cuyas obligaciones se encuentren vencidas y sobre las cuales recaigan procesos judiciales, tendrán derecho a solicitar suspensión de los mencionados procesos. Dicha suspensión podrá otorgarse automáticamente por el juez respectivo. En caso de que el deudor acuerde la 
reliquidación de su obligación, de conformidad con lo previsto en este artículo el proceso se dará por terminado y se procederá a su archivo sin más trámite."

De los diversos alcances que los operadores jurídicos le han dado a la norma, esta Corporación ha venido reiterando que su texto, leído en consideración a la finalidad de la Ley 546 de 1999 y a la luz de la sentencia C955 de 2000, debe ser entendida de la siguiente manera pues es la interpretación que más se adecua a las disposiciones Superiores:

“(...), en la medida en que la única hipótesis de continuación de los ejecutivos que habían sido suspendidos fue declarada inexequible por la sentencia C955 de 2000, resulta claro que el efecto de dicha sentencia de la Corte Constitucional fue dar por terminados todos los procesos ejecutivos con título hipotecario basados en un crédito UPAC y que se encontraban en curso el 31 de diciembre de 1999." (sentencia T-701 de 2004, M.P. Rodrigo Uprimny Yepes)

CORTE SUPREMA DE JUSTICIA. Sentencia de Tutela Septiembre 30 de 2002. Expediente 00413-01.

La Corte analizando la sentencia de tutela mencionada argumenta:

No hay prueba suficiente que conduzca a concluir que la obligación quedó al día, ni que las partes comprometidas hayan convenido la refinanciación de la misma, no era viable desde el punto de vista legal, dar por terminado de plano el proceso ejecutivo hipotecario con la sola presentación de la reliquidación y sin ninguna clase de evaluación. 
Argumentos inclinados a sostener, que no era suficiente practicar la reliquidación del crédito para terminar un proceso, pues, es de suma importancia que si se efectuó la misma, debía haberse comprobado que quedo al día con la obligación, o por lo menos, que el deudor hipotecario hubiera solicitado la reestructuración del crédito, en donde se pactan nuevas condiciones, subsanando de esta forma, la mora adeudada a la fecha.

CORTE SUPREMA DE JUSTICIA. Sentencia 1033 de Septiembre 29 de 2.004. Magistrado Ponente: Manuel Isidro Ardila Velásquez. Expediente No. 110010203000200401033. Frente al tema de discusión esto opinó la corte:

Frente al tema de discusión esto opinó la corte:

Parece no ofrecer duda que el ejercicio jurisdiccional de control constitucional se agota con la expedición de la sentencia, o por lo menos ello es lo que demandan los cánones; no obstante, ahora surge la desmesura consistente en que una Sala de Revisión de tutela se arroga el privilegio de colocar en circulación esta especie novísima de ley que ordena la terminación de todos los procesos ejecutivos hipotecarios vigentes a 31 de diciembre de 1999, siendo que tal cosa no dijeron ni el legislador, ni el juez constitucional que expidió la sentencia original. Los jueces constitucionales de entonces quedaron debiendo la explicación que hoy pretende hacer una sala de revisión de tutela compuesta por otros jueces, y no en materia apenas accidental, sino en asunto tan grave como poner término a ochocientos mil procesos ejecutivos, que ese número cita la misma sentencia en uno de sus apartes. Por supuesto que una decisión de tal alcance, que entre otras cosas causará 
una inusitada descongestión judicial, no tiene precedentes en el país y por lo mismo no se esperaría encontrarla en los vericuetos de la frondosa argumentación del juez constitucional, sino en una orden perentoria y clara del legislador. No ha de olvidarse que desde siempre el legislador ha regulado de manera minuciosa las causas de terminación anormal del proceso, como que en el código de procedimiento civil hay un capítulo especial reservado a este tema. Igualmente no debe perderse de vista que el legislador ha considerado muy importante la decisión por la cual se dispone la terminación del proceso, tanto, que para ella ha dispuesto el control de la doble instancia. Por lo que acaba de decirse parece inusitado que se haya podido crear, leyendo entre lo dicho al pasar de una sentencia de constitucionalidad, no calificada por el propio juez constitucional como modulada ni condicionada, una causal de terminación del proceso de tan hondas repercusiones para el derecho de los acreedores a acceder a la administración de justicia. Por el margen de inseguridad e incertidumbre que tal procedimiento apareja, la razón se resiste a tolerar que so capa de descifrar el sentido de una sentencia de constitucionalidad, se pueda dictar una nueva de idéntico linaje, y no sólo una, sino todas las que el futuro sean necesarias, según la necesidad de la acción de tutela de turno.

Amén de las razones de orden constitucional que anteceden y preocupan, importa recordar que de la sentencia que declaró la exequibilidad de la ley 546 de 1999, siendo que ésta por cierto aludió a la posibilidad de suspender los procesos ejecutivos en curso para facilitar la reliquidación de los créditos, no surgía ineluctablemente la terminación ope legis del proceso 
ejecutivo, por el solo hecho de que obre aquélla, como si tal proceso no tuviera por mira en últimas la satisfacción del crédito, mucho más cuando el presupuesto de esa terminación, según los términos de le sentencia C-955 de 26 de julio de 2000 y de la ley misma que fue objeto de revisión, se hizo depender del acuerdo a que se llegue con el deudor, sobre la refinanciación o el finiquito de la deuda.

Desde ese punto de vista observó esta Corporación al definir tutelas sobre el particular que cuando "no hay prueba suficiente que conduzca a concluir que la obligación quedó al día, ni que las partes comprometidas hayan convenido la refinanciación de la misma, no era viable desde el punto de vista legal, dar por terminado de plano el proceso ejecutivo hipotecario con la sola presentación de la reliquidación y sin ninguna clase de evaluación" (sentencia de tutela 00413-01 de 30 de septiembre de 2002). Claro está que, si así no fuera, seguramente la ley en lugar de establecer la posibilidad de suspender el proceso habría provocado la terminación de todos los procesos ejecutivos para que fuera posteriormente y en otro trámite que se provocara la satisfacción de los créditos que, a pesar de la reliquidación, quedaran insolutos. Desde luego que la suspensión que manda la norma sería manifiestamente estéril, si la vocación de los procesos era su terminación "sin consideración al estado del mismo, ni la cuantía del abono especial, como tampoco de las 'gestiones' del deudor para cancelar las cuotas insolutas del crédito" como lo estima la Corte Constitucional en la sentencia T 606 de 23 de julio de 2003. 
CORTE SUPREMA DE JUSTICIA. Sentencia del 29 de Septiembre de 2.004. Magistrado Ponente: Manuel Isidro Ardila Velásquez. Exp. 110010203000200401033.

Al respecto la corte dice que:

Desde ese punto de vista observó esta Corporación al definir tutelas sobre el particular que cuando "no hay prueba suficiente que conduzca a concluir que la obligación quedó al día, ni que las partes comprometidas hayan convenido la refinanciación de la misma, no era viable desde el punto de vista legal, dar por terminado de plano el proceso ejecutivo hipotecario con la sola presentación de la reliquidación y sin ninguna clase de evaluación" (sentencia de tutela 00413-01 de 30 de septiembre de 2002). Claro está que, si así no fuera, seguramente la ley en lugar de establecer la posibilidad de suspender el proceso habría provocado la terminación de todos los procesos ejecutivos para que fuera posteriormente y en otro trámite que se provocara la satisfacción de los créditos que, a pesar de la reliquidación, quedaran insolutos. Desde luego que la suspensión que manda la norma sería manifiestamente estéril, si la vocación de los procesos era su terminación "sin consideración al estado del mismo, ni la cuantía del abono especial, como tampoco de las 'gestiones' del deudor para cancelar las cuotas insolutas del crédito" como lo estima la Corte Constitucional en la sentencia T 606 de 23 de julio de 2003.

CORTE SUPREMA DE JUSTICIA. Sentencia de enero 20 de 2005. Magistrado Ponente: Edgardo Villamil Portilla. Expediente 01484 - 00 
La corte Suprema de justicia dice que:

Obvio que en ese sentido ésta Corporación se aparta de la conclusión en contrario que por vía de tutela, que no de exequibilidad de las normas, dedujo la Corte Constitucional en la sentencia T- 606 de 2.003.

La Corte Suprema, argumenta que comparte lo concerniente a la constitucionalidad de las normas, pero se aleja de la conclusión de lo manifestado por la sentencia T-606 de 2.003, con el argumento de que a pesar de la reliquidación, cuando la obligación no queda solucionada según lo requieren las normas sustanciales y procesales sobre la materia, no puede aspirarse a que el proceso permanezca suspendido definitivamente, o que se dé por terminado sin más requisitos, porque no es tal el efecto perseguido por la ley citada (refiere las Sentencias de 14 de noviembre de 2000 -exp. 00122-, 17 de abril de 2001 -exp. 10017-, 5 de abril y 31 de julio de 2002 -exps. 20023-01 y 00266-01).

CONSEJO DE ESTADO, Sala de lo Contencioso Administrativo, Sección Quinta, Sentencia del 12 de diciembre de 2002, CP Mario Méndez:

Según lo establecido en el parágrafo $3^{\circ}$ del artículo 42 de la ley 546 de 1999, y de conformidad con la sentencia C-955 de 26 de julio de 2000 dictada por la Corte Constitucional, producida la reliquidación del crédito debió terminarse el proceso y su archivo, sin más trámite. $\mathrm{Y}$ la nueva mora en que se incurriera daría a la iniciación de un nuevo proceso contra los deudores, pero no podía acumularse a la que había motivado inicialmente el proceso ejecutivo iniciado por Concasa contra los demandantes. 
Así las cosas, considerando que en este caso existe una irregularidad evidente, para garantizar el derecho al debido proceso de los demandantes, que ha sido violado, se hace necesario ordenar a la juez Quinta Civil del Circuito de Barranquilla que en un plazo perentorio de 48 horas contadas desde la notificación de esta sentencia declare la terminación del proceso ejecutivo hipotecario instaurado por Concasa, hoy Bancafé y su archivo, sin más trámite, de conformidad con lo establecido en el parágrafo 3 del artículo 42 de la ley 546 de 1.999.

En este caso, el Consejo de estado tutela el debido proceso a favor de los solicitantes, argumentando la sentencia C-955 de 2.000, en el sentido de que una vez reliquidado el crédito independientemente haya o no quedado al día la obligación deberá terminarse el proceso.

TRIBUNAL SUPERIOR DEL DISTRITO JUDICIAL DE BOGOTÁ, Sala Civil, Noviembre 21 de 2.005, Magistrado Ponente Dra. LIANA AIDA LIZARAZO V:

4. De otra parte, no le asiste la razón al a-quo al considerar que debía terminar el proceso por virtud de la reliquidación del crédito aduciendo la aplicación del parágrafo 3ำ del art. 42 de la Ley 546 de 1999 y de unos fallos de tutela de la Corte Constitucional.

En efecto, el parágrafo 3 del artículo 42 de la ley 546 de 1999, luego de estudiada la constitucionalidad en la sentencia C-955 de 1999, establece que "Los deudores cuyas obligaciones se encuentren vencidas y sobre las cuales recaigan procesos judiciales, tendrán derecho a solicitar suspensión 
de los mencionados procesos. Dicha suspensión podrá otorgarse automáticamente por el juez respectivo, en caso de que el deudor acuerde la reliquidación de su obligación, de conformidad con lo previsto en este artículo el proceso se dará por terminado y se procederá a su archivo sin más trámite."

De tal precepto no se desprende que la ley haya ordenado de manera categórica y automática la terminación de todos los procesos ejecutivos iniciados antes del 31 de diciembre de 1999, pues existe un condicionamiento para ello, cual es "el acuerdo del deudor" con la reliquidación de la obligación.

El parágrafo en mención plantea los siguientes aspectos: el primero, la suspensión de los procesos en curso para la vigencia de la ley con el fin de que se realizará la reliquidación, y el segundo, el acuerdo del deudor a la reliquidación d su obligación y así se de por terminado el proceso.

Así, una interpretación teleológica de la norma conduce a que si una vez efectuada la reliquidación por la parte demandante, condonados los intereses y aplicado el alivio, la obligación continuaba en mora, el juicio no podía terminarse pues debía proseguir por el valor insoluto. Empero, si practicada la reliquidación y el deudor llega a acuerdo con la entidad sobre la refinanciación de la deuda o la forma para colocarse al día el proceso podía finalizarse sin más trámite, terminación que acontecería también en el evento que verificada la reliquidación, la obligación quedó al día o completamente solucionada. 
5. Frente a la aplicación del parágrafo $3^{\circ}$ del art. 42 de la ley de vivienda, la $\mathrm{H}$. Corte Suprema de Justicia se ha pronunciado señalando si bien la sentencia que declaró la exequibilidad de la Ley 546 de 1999 "aludió a la posibilidad de suspender los ejecutivos en curso para facilitar la reliquidación ope legis del proceso ejecutivo, por el solo hecho de que obre aquélla, como si tal proceso no tuviera como mira en últimas la satisfacción del crédito, mucho más cuando el presupuesto de esa terminación, en los términos de la sentencia C-955 del 26 de julio de 2000 y de la ley misma que fue objeto de revisión se hizo depender del acuerdo a que se llegue con el deudor, sobre la refinanciación o finiquito de la deuda.

Posteriormente, tal Corporación reiteró sobre el tema lo siguiente: Ha sido copiosa y unánime la jurisprudencia de la Corte Suprema de Justicia en el punto atinente a la aplicación del parágrafo $3^{\circ}$ del artículo 42 de la Ley 546 de 1999 y sus efectos en los proceso ejecutivos y para denegar el amparo basta con citar entre otras la providencia de esta misma Sala vertida en el expediente de tutela 6800122030020030011-01 en un caso similar en la que se dijo que: "Es claro para la Sala que no le asiste razón al demandante al formular la queja constitucional, pues es evidente que el despacho accionado no incurrió en vía de hecho en el trámite del proceso ejecutivo adelantado en su contra al no terminar el proceso, con fundamento en el parágrafo $3^{\circ}$ del artículo 42 de la Ley 546 de 1999, por cuanto no estaban cumplidos los requisitos exigidos en dicha norma para esos efectos. 
Surge de manera clara si el querer del legislados hubiera sido la terminación de los juicios en curso, así lo habría dispuesto, en lugar de establecer una suspensión para posteriormente ordenar la finalización automática de los procesos, sin importar los resultados que arrojará la reliquidación y el acuerdo del deudor con la entidad financiera, pues arribar a tal conclusión provocaría que al día siguiente se iniciara un nuevo proceso con el consiguiente desgaste jurisdiccional generando congestión en los despacho judiciales, lo que socavaría principios del procedimiento como el de la economía procesal.

Como la finalidad del proceso ejecutivo con título hipotecario es el pago de la obligación "en dinero con el solo producto de los bienes gravados con hipoteca o prenda" (art. 554 del C.P.C.), no resulta comprensivo que iniciado un juicio con tal fin este deba terminarse sin obtenerlo. “

El tribunal, claramente da alcance a la doctrina constitucional de manera opuesta, a lo expuesto en varias oportunidades por la corte, interpretando en dos sentidos el contenido del Parágrafo objeto de estudio. El primero, en donde si efectuada la reliquidación y aplicado el alivio la obligación continuaba en mora, el proceso no podía terminarse, por que debería seguirse por el saldo insoluto de la obligación. El segundo, en donde una vez practicada la reliquidación, el deudor acudía a la entidad financiera para llegar a un acuerdo sobre la refinanciación de la deuda,- es decir reestructuración-, el proceso podía finalizar sin más trámite. 
TRIBUNAL SUPERIOR DEL DISTRITO JUDICIAL DE BOGOTÁ, Sala Civil, Mayo de 2.005, Magistrado Ponente Dr. RICARDO SOPÓ MÉNDEZ:

Considera necesario precisar que al señalar el parágrafo 3ํ del artículo 42: “En caso de que el deudor acuerde la reliquidación de su obligación, de conformidad con lo previsto en este artículo el proceso se dará por terminado y se procederá a su archivo sin más trámites", dicha terminación debe partir de la existencia de un acuerdo entre el deudor y el acreedor que apunte a reestructurar el crédito, mas no a la simple reliquidación del mismo como lo señaló el a quo en el auto recurrido.

En ésta oportunidad, el tribunal a través de su magistrado ponente asume la interpretación de que el significado de "acuerde la reliquidación" debe interpretarse y partir de la base de un acuerdo entre los extremos del contrato que apunte a que se hizo una reestructuración de la obligación.

TRIBUNAL SUPERIOR DEL DISTRITO JUDICIAL DE BOGOTÁ- Sala Civil, Sentencia mayo 27 de 2.005, Magistrado Ponente: José Alfonso Isaza Dávila:

No puede afirmarse que con sólo efectuarse la reliquidación, haya lugar a la terminación automática de los procesos en curso, porque meridiano es que el precepto contempló un supuesto de hecho para consecuencia semejante, cual es que se acordase la "reestructuración" del crédito: "en caso de que el deudor acuerde la reliquidación de su obligación, de conformidad con lo previsto en 
este artículo el proceso se dará por terminado y se procederá a su archivo sin más trámite". Entonces se inclina por una interpretación gramatical según la cual el sentido de la norma es "reestructuración" en lugar de "reliquidación"

Pues bien, quise con esta descripción jurisprudencial, ilustrar el problema suscitado en el desarrollo de los contratos de mutuo para financiamiento de vivienda, debido a las interpretaciones excluyentes que recibió el parágrafo 3ํㅜ del artículo 42 de la ley 546 de 1999 con las que se presentaron las terminaciones y continuaciones de los procesos ejecutivos hipotecarios iniciados con anterioridad al 31 de Diciembre de 1999.

Finalmente, tendremos que hacernos la pregunta de rigor. ¿ Que paso y que ha pasado hoy en día con esta discusión?. La Corte Constitucional, a través de la sentencia SU-813 del 4 de Octubre de 2.007, unificó la jurisprudencia constitucional y dio los parámetros jurídicos para que los operadores judiciales tuvieran en cuenta, previo a tomar alguna decisión sobre la terminación o no de los procesos hipotecarios iniciados antes del 31 de Diciembre de 1999. Así las cosas procederemos a abordar y desarrollar este tema concretamente analizando la sentencia aludida. 


\section{ANÁLISIS DE LA SENTENCIA DE UNIFICACIÓN DE LA CORTE CONSTITUCIONAL, SU-813 DEL 4 DE OCTUBRE DE 2007}

Teniendo en cuenta la problemática presentada con el parágrafo 3 del artículo 42 de la ley 546 de 1.999 y el sin número de tutelas presentadas por los deudores hipotecarios contra los operadores judiciales que compartían la tesis de que los procesos ejecutivos hipotecarios deberían continuar, cuando una vez efectuada la reliquidación del crédito ordenada por dicha ley, y aplicado el alivio respectivo el crédito hipotecario continuaba en mora, la Corte Constitucional, una vez remitidos los expedientes de las respectivas salas de selección dispuso la revisión, ordenando mediante decisión del 7 de marzo de 2.007 la acumulación de todos los expedientes a la tutela T-1334615 que tuvieran que ver con la mismas situaciones de hecho y de derecho, para que conforme al principio de economía procesal y celeridad se les diera trámite en una misma sentencia.

No es un secreto que la Corte Constitucional en su juicio de constitucionalidad del artículo 42 de la ley 546 de 1999 y en los diferentes fallos de tutela, tuvo y tiene como criterio de alguna $u$ otra forma, que todos los procesos ejecutivos hipotecarios que se encontraban en curso con anterioridad al 31 de Diciembre de 1.999 debían declararse terminados por parte del juez competente, por encontrarse estrechamente ligada la terminación de los procesos con el derecho fundamental al debido proceso en conexidad con el derecho a la vivienda digna y como consecuencia de ello, si los jueces de primera o segunda instancia no protegen el derecho a la terminación de los mencionados procesos, generan en los deudores la facultad de acudir a la acción de 
tutela como mecanismo excepcional y subsidiario de defensa de los derechos fundamentales.

Por esto, en la sentencia de unificación se hace un verdadero estudio sobre la procedencia de la tutela contra providencias judiciales y la verdadera aplicación de la doctrina constitucional para resolver los casos concretos, lo cual procederé a describir, por ser el pilar fundamental de la motivación y posterior toma de decisión de tan mencionado fallo.

En primer lugar, la Corte hace un estudio general de los requisitos de procedibilidad de la acción de tutela contra decisiones judiciales, recordando las causales generales y específicas de procedibilidad de la acción, donde las primeras tienden a garantizar que no exista abuso en el derecho de acción, así como los deberes mínimos procesales de las partes (deber de lealtad, diligencia, etc) en pro de la constitucionalización del derecho legislado como efecto fundamental de la tutela contra providencias judiciales y las segundas, destinadas a evitar que los jueces constitucionales usurpen las facultades de los jueces ordinarios (interpretación del derecho legislado y valoración de las pruebas).

En segundo lugar, la corte aplica los conceptos generales para tomar partido y decidir cuáles son los presupuestos específicos para que proceda la tutela en aquellos casos en que los deudores desean interponer la acción de tutela frente a aquellos operadores judiciales que no decretaron la terminación de los procesos. (Corte Constitucional. Sentencia SU 813 de 2007).

Así las cosas, la Corte Constitucional al hacer el estudio de las causales de procedibilidad en la mencionada Sentencia manifiesta lo siguiente: 
"Las causales genéricas de procedibilidad se refieren a aquellos requisitos que en general se exigen para la procedencia de la acción de tutela, pero que referidas al caso específico de la tutela contra providencias judiciales adquieren un matiz especial. La particularidad se deriva del hecho de que en estos casos la acción se interpone contra una decisión judicial que es fruto de un debate procesal y que en principio, por su naturaleza y origen, debe entenderse ajustada a la constitución. Tales causales son las siguientes:

(i) Se requiere, en primer lugar, que la cuestión discutida resulte de evidente relevancia constitucional y que, como en cualquier acción de tutela, esté acreditada la vulneración de un derecho fundamental, requisito sine qua non de esta acción de tutela que, en estos casos, exige una carga especial del actor; (ii) que la persona afectada haya agotado todos los medios ordinarios y extraordinarios de defensa judicial a su alcance y haya alegado, en sede judicial ordinaria, y siempre que ello fuera posible, la cuestión ius fundamental que alega en sede de tutela; (iii) que se cumpla el requisito de la inmediatez, es decir, que la tutela se hubiere interpuesto en un término razonable y proporcionado a partir del hecho que originó la vulneración; (iv) en el caso de irregularidades procesales, se requiere que éstas tengan un efecto decisivo en la decisión de fondo que se impugna; y (v) que no se trate de sentencias de tutela.

Finalmente, para que proceda la tutela, es necesario que la decisión judicial impugnada incurra en defectos o fallas graves. En particular puede incurrir en uno de los siguientes defectos: (i) defecto orgánico, que se presenta cuando el funcionario judicial que profirió la providencia impugnada, 
carece, absolutamente, de competencia para ello; (ii) defecto procedimental absoluto, que se origina cuando el juez actuó completamente al margen del procedimiento establecido o vulneró de manera definitiva el debido proceso constitucional del actor; (iii) defecto fáctico, que surge cuando el juez carece del apoyo probatorio que permita la aplicación del supuesto legal en el que se sustenta la decisión o cuando deja de decretar o de valorar pruebas absolutamente necesarias - imprescindibles y pertinentes - para adoptar la decisión de fondo; (iv) defecto material o sustantivo, que surge cuando el juez decide con base en normas inexistentes o inconstitucionales; cuando se presenta una evidente y grosera contradicción entre los fundamentos y la decisión; cuando hay absoluta falta de motivación; o cuando la Corte Constitucional como interprete autorizado de la constitución, establece, con carácter de precedente, el alcance de un derecho fundamental y el juez ordinario, sin motivación suficiente, contraría dicha decisión; (v) error inducido, que se presenta cuando el juez o tribunal fue víctima de un engaño o error grave, por parte de terceros y ese engaño o error, lo condujo a la toma de una decisión que afecta derechos fundamentales. En todo caso, la acción no podrá tener por objeto que el juez de tutela se convierta en una nueva instancia, ni tampoco que entre a resolver discusiones propias del proceso (como la interpretación simple de la ley o la valoración de las pruebas) que no representen un problema constitucional de vulneración de derechos fundamentales. 
Seguidamente y teniendo en cuenta lo anterior, la Corte Constitucional procede a aplicar las causales mencionadas en la tutela, contra decisiones judiciales que no decretan la terminación de los procesos ejecutivos hipotecarios a 31 de diciembre de 1.999, de la siguiente forma.

Respecto del primer requisito y que corresponde a que se encuentre acreditada la vulneración de un derecho fundamental, en los casos de los procesos ejecutivos hipotecarios que se encontraban en curso el 31 de Diciembre de 1.999, lo que se pretende es hacer valer el derecho fundamental al debido proceso en conexidad con el derecho a la vivienda digna. Dice la corte:

En efecto, como desarrollo de mandatos constitucionales, el legislador modificó el sistema de financiación de vivienda. Con la finalidad de que este nuevo sistema permitiera a los deudores conservar sus viviendas, la ley 546 de 1999 estableció que los créditos hipotecarios debían ser reliquidados y una vez acordada la reliquidación entre deudor y acreedor debían terminarse los procesos ejecutivos vigentes a 31 de diciembre de 1999. Solo ante un nuevo incumplimiento del deudor, en las condiciones fijadas por la ley 546 de 1999 mencionada, podía comenzar un nuevo proceso para el cobro ejecutivo de la (nueva) obligación incumplida. En este sentido, el derecho a la terminación de los juicios era un derecho procesal directamente vinculado con el derecho a conservar una vivienda digna. (Sentencia SU-813 de 2007).

En consecuencia de lo anterior, la tutela, en cuanto a este requisito, será procedente y vale la pena aclarar, siempre y cuando, - como en otro de sus apartes 
dijo la corte, - se trate de procesos hipotecarios derivados de obligaciones para satisfacción del derecho a la vivienda -

Respecto del segundo requisito y que corresponde a que la persona afectada haya acudido a los medios ordinarios y extraordinarios de defensa judicial, se le impone al deudor una carga procesal mínima, que consiste en que los deudores hayan solicitado a los jueces la terminación del proceso ejecutivo hipotecario o la nulidad del mismo por haber continuado ilegalmente en cualquier etapa del proceso. Dice la corte:

En primer lugar por que la acción de tutela no es un mecanismo para suplir la inactividad por negligencia(...)En segundo lugar por que la inactividad procesal tiene efectos claros en materia de derechos e intereses legítimos de terceros que el ordenamiento jurídico no puede simplemente desatender (...) Y, finalmente, por que como ya se dijo, uno de los propósitos de la subsidiariedad de la tutela contra providencias judiciales, radica en que el juez ordinario pueda pronunciarse, en primera instancia, sobre la cuestión constitucional debatida. (Sentencia SU-813 de 2007).

Respecto del tercer requisito y que corresponde a que se cumpla con la inmediatez, es decir que la tutela se interponga dentro de un término razonable, y en el caso objeto de estudio, una vez proferido el fallo que niega la terminación del proceso, debemos tenerlo en cuenta, a pesar de que no existe un término de caducidad señalado por la constitución ni la ley, Dice la corte: 
Sin embargo, cuando se está frente a una eventual vulneración de la Constitución, producida por una decisión judicial que el afectado no controvierte y el paso del tiempo da lugar a que se consoliden situaciones jurídicas que favorecen derechos fundamentales de terceros de buena fe, o bienes constitucionalmente protegidos de igual importancia que los derechos que se persiguen proteger, la corte ha considerado necesario aplicar el llamado principio de la inmediatez. (...) En el caso concreto de los procesos ejecutivos hipotecarios, existe un término razonable dentro del cual la persona afectada debe defender sus derechos para evitar una lesión posterior de los derechos fundamentales de terceros o de intereses constitucionalmente protegidos. En este sentido, la Corte encuentra que la tutela sólo puede proceder si se interpone en cualquier momento, desde la decisión judicial de no dar por terminado el proceso, hasta el registro del auto aprobatorio del remate, es decir, hasta que se perfecciona la tradición del dominio del bien en cabeza de un tercero cuyos derechos no pueden ser desconocidos por el juez constitucional. En efecto, una vez realizado el registro, la persona ha perdido su oportunidad de alegar en tutela pues ya existe un derecho consolidado en cabeza de terceros de buena fe, que el juez constitucional no puede desconocer. (Sentencia SU-813 de 2007).

Respecto del cuarto requisito, dice la corte:

...consiste en verificar que las irregularidades procesales tengan o puedan tener un efecto decisivo en la decisión judicial de fondo. En estos casos la 
decisión de no terminar los procesos ejecutivos podía conducir a la perdida de la vivienda del deudor. Por esta razón, frente a procesos ejecutivos hipotecarios en curso a 31 de diciembre de 1999, este requisito se entiende satisfecho. (Sentencia SU-813 de 2007

Respecto del quinto requisito, es decir, las denominadas vías de hecho, dice la corte:

...la decisión judicial de no terminar los procesos ejecutivos hipotecarios en curso a 31 de diciembre de 1.999, constituye una vía de hecho por defecto sustantivo. En efecto, la vía de hecho sustantivo se configura cuando "la decisión se encuentre fundada en una norma claramente inaplicable al caso concreto"(...) En síntesis, para la corte la decisión de los jueces de no dar por terminados dichos procesos, es constitutiva de una vía de hecho por defecto sustantivo. La vía de hecho se configura por desconocimiento del precedente constitucional aplicable, en especial, por lo dispuesto en la sentencia C-955 de 2000 que juzgó a la ley 546 de 1999 en el punto estudiado, interpretado posteriormente, con autoridad, por las sentencias de tutela proferidas por las salas de revisión de la corte. (Sentencia SU-813 de 2007).

De esta manera vemos claramente, cómo la Corte Constitucional, de lo general a lo particular, establece los presupuestos indispensables que debe contener una tutela contra sentencias judiciales, concretamente respecto de aquellas providencias que no decretaron la terminación de los procesos ejecutivos hipotecarios iniciados con anterioridad al 31 de diciembre de 1999. 
En este orden de ideas el juez debe tener en cuenta la mínima diligencia, si se interpuso dentro del término y si se cumplió obviamente con los requisitos legales para que se de la terminación, es decir, que el proceso se haya iniciado con anterioridad al 31 de diciembre de 1.999 y que se haya efectuado la reliquidación del crédito; para el efecto dice la corte:

... En éste sentido, la declaratoria de la terminación del proceso no es automática, ni ajena a los hechos de cada caso y a las condiciones fijadas en la ley. En su análisis el juez de tutela ha de establecer cuando menos, (1) si el actor tuvo una mínima diligencia en la defensa de sus derechos constitucionales en el proceso ejecutivo; (2) si interpuso la acción dentro del término que corre entre la decisión judicial de no terminar el proceso y el registro del auto aprobatorio del remate; (3) si se cumplían los requisitos legales necesarios para la terminación de los procesos ejecutivos hipotecarios, a la luz de la ley 546 de 1.999, tal como quedó después de la sentencia C-955 de 2.000. (Sentencia SU813 de 2007).

Ahora, si bien es cierto que hasta ahora nos hemos enfocado a los requisitos que se deben tener en cuenta para la prosperidad de la interposición de las tutelas en esta clase de asuntos, no lo es menos cierto, que el fallo de la corte le traslada una gran responsabilidad a los jueces civiles de primera o segunda instancia al obligarlos a dar cumplimiento al precedente constitucional, pues en tal sentido y de acogerse el mismo, los deudores hipotecarios que iniciaron sus procesos antes de la fecha ya enunciada verían satisfechos y protegidos sus derechos constitucionales y principios fundamentales, como lo son el derecho a la vivienda digna y el debido 
proceso respectivamente, cuando el juez de instancia decreta la terminación de los mismos. En tal sentido la corte dice:

Con el fin de asegurar la terminación del proceso ejecutivo hipotecario y el archivo del expediente de conformidad con la ley 546 de 1.999 y con la jurisprudencia de esta corte. El juez civil respectivo procederá a adoptar las siguientes decisiones: (a) solicitar al deudor que manifieste si esta de acuerdo con la reliquidación y en caso de objeción, la resuelva de conformidad con los términos establecidos en la ley. (b) Definida la reliquidación, el juez procederá de oficio a dar por terminado el proceso, sin que haya lugar a condena en costas. En la misma providencia, ordenaría al acreedor que reestructure el saldo de la obligación e impartirá las demás órdenes que correspondan, según las circunstancias del caso. Si entre el 16 de agosto de 2006 y el 4 de octubre de 2007, se hubiere registrado el auto aprobatorio del remate o de adjudicación del inmueble, y no se hubiere hecho la entrega material del bien, el juez civil ordenará la cancelación de éste registro y el reembolso del dinero al rematante a cargo de la entidad ejecutante. (c) Para los efectos anteriores, el juez también ordenaría a la entidad financiera ejecutante que reestructure el saldo de la obligación vigente a 31 de diciembre de 1.999, de conformidad con la ley 546 de 1.999 y la sentencia C-955 de 2000 y sin el cómputo de los intereses que pudieren haberse causado desde el 31 de diciembre de 1.999. La reestructuración deberá tener en cuenta criterios de favorabilidad y viabilidad del crédito, así como la situación económica actual del deudor. En todo caso, deberá 
atender a las preferencias del deudor sobre alguna de las líneas de financiación existentes o que se creen. En el caso de existir desacuerdo irreconciliable entre la entidad financiera y el deudor corresponderá a la superintendencia financiera definir lo relativo a la reestructuración del crédito en estricta sujeción a los criterios mencionados y dentro de un plazo no superior a 30 días, contados a partir de la solicitud presentada por cualquiera de las partes. En ningún caso podrá cobrarse intereses causados antes de definida la reestructuración del crédito. No sería exigible la obligación financiera hasta tanto no termine el proceso de reestructuración. (Sentencia SU-813 de 2007). 


\section{ACIERTOS Y DESACIERTOS DE LA SENTENCIA DE UNIFICACIÓN SU- 813 DEL 4 DE OCTUBRE DE 2.007 DE LA CORTE CONSTITUCIONAL}

Finalmente, y una vez resueltas las tutelas en favor de los accionantes en su gran mayoría que cumplían los requisitos establecidos por la corte y que fueron enunciados explicados en incisos anteriores, llama la atención que la corte exhorto al Congreso de la República y al Gobierno Nacional para que en cumplimiento de la Constitución, ejerzan funciones dirigidas a satisfacer el derecho a la vivienda digna, a través de planes de interés social y acceso equitativo de financiación a largo plazo, actualización de la información en los bancos de datos de las entidades financieras, así como la redefinición de líneas de crédito con intereses y plazos adecuados razonables para los deudores, ordenando que aquellas políticas de vivienda que se adopten tendrán prevalencia las personas que perdieron su vivienda como efecto del incumplimiento de la ley 546 de 1.999.

De todo lo anterior podemos decir, que este fallo tiene más aciertos que desaciertos; así las cosas, veamos los aciertos a través de tres conclusiones que en mi criterio son muy positivas:

La primera, que los efectos de esta sentencia de unificación no sólo resuelven las tutelas objeto de estudio y que generaron el presente fallo, sino que estos mismos criterios deben tenerse en cuenta y deben extenderse con carácter general a todos los procesos ejecutivos hipotecarios derivados de créditos de vivienda en curso, iniciados antes del 31 de diciembre de 1.999.

La segunda, que los jueces civiles deberán dar cumplimiento al precedente constitucional decretando la terminación de los procesos ejecutivos hipotecarios 
iniciados antes del 31 de diciembre de 1999, sin necesidad de tutela, acogiendo los parámetros aquí señalados.

Y la tercera, se ordena al Congreso de la República y al Gobierno Nacional adoptar políticas conducentes a hacer efectivo el derecho a la vivienda digna, dando prevalencia a aquellos deudores que perdieron sus viviendas por el incumplimiento de la ley de vivienda.

En cumplimiento de lo anterior, ya vemos que los deudores hipotecarios dejaron, en su gran mayoría, de instaurar tutelas frente a éste tema, pues, de igual forma la gran mayoría de los juzgados han cumplido con las directrices dadas por la Corte constitucional para establecer jurídicamente cuando es viable decretar la terminación de los procesos. De igual forma, hoy en día ya vemos las diferentes políticas que en materia de vivienda tiene el gobierno nacional, por un lado, propendiendo a la conquista de los usuarios del sistema financiero para acceder a una vivienda digna en sus diferentes tipos y modalidades (Compra de Vivienda y leasing habitacional, ambas en Pesos y UVR), aplicando las tasa de interés que para ello especialmente fueron creadas, y que garantizan una estabilidad en la financiación; y por otro lado, la implementación de nuevas políticas gubernamentales para garantizar el acceso a vivienda para los más pobres.

Entre los desaciertos, veámoslo también, a través de tres conclusiones:

La primera, Que se pueden generar posibles perjuicios de carácter patrimonial a las entidades financieras, deudores hipotecarios y personas naturales intervinientes en el proceso; así, como de índole moral para éstas últimas. 
La segunda, Que se pueden generar malas interpretaciones del presente fallo por parte de los operadores judiciales.

La tercera, que se pueden generar violaciones a derechos constitucionales.

En lo que respecta al posible perjuicio que se genera a los acreedores hipotecarios, para nadie es un secreto que los bancos deberán efectuar un trámite extraprocesal para lograr citar a los deudores con el fin de lograr el "acuerdo de reestructuración", que genera demoras en el recaudo del pago de la obligación y en su defecto, una traba para iniciar las acciones judiciales nuevamente ocasionado perjuicios por la demora en la satisfacción de la realización de la garantía. Frente a los terceros de buena fe, que libre y espontáneamente solicitaron la adjudicación del bien para cancelar la obligación por cuenta del crédito, o que compraron mediante subasta el inmueble objeto de venta forzada, respectivamente; pues la Corte, ordena que si entre el 16 de Agosto de 2006 y el 4 de octubre de 2007, se hubiere registrado el auto aprobatorio del remate o de adjudicación del inmueble, y no se hubiere hecho la entrega material del bien, el juez ordenaría la cancelación de este registro y el reembolso del dinero al rematante a cargo de la entidad ejecutante, creando perjuicios al rematante que con base en normas procesales vigentes al momento de la diligencia de remate, invirtió posiblemente su único patrimonio, causando demoras y expectativas en la devolución de su dinero; o que muy posiblemente hayan tenido que endeudarse para obtener los recursos con que pudo hacer postura en la diligencia de remate y realizar la mejor oferta en la venta en pública subasta; o que aprovechando el título de propietario por compra efectuada 
en subasta judicial, hubiera vendido su nuevo inmueble y el nuevo propietario a su vez hubiera hecho lo mismo y así sucesivamente.

Así las cosas, lo único que crea la decisión de la Corte son problemas jurídicos que no eran previsibles para la fecha de la compra a través de subasta pública para los adquirentes de buena fe y mucho menos cuando "supuestamente" esta clase de actos jurídicos celebrados con intermediación del juez, se encuentran revestidos de total seguridad jurídica y amparo legal.

Y finalmente los perjuicios al deudor, pues el hecho de que pueda hacer una reestructuración de la obligación, sin incluir cobro de intereses, ello implica en muchos casos, solucionar el problema financiero.

En lo que respecta a las malas interpretaciones, si bien es cierto la mayoría de los juzgados han interpretado en debida forma las indicaciones del fallo de unificación, no es menos cierto, que hoy en día algunos jueces no han entendido el contenido de aquel, pues en aras de cumplir el objetivo fundamental del fallo de unificación, la corte expresó que una vez decretada la terminación de los procesos, los deudores debían acudir al banco respectivo para "acordar la reestructuración del crédito" con el fin de establecer nuevos saldos, nuevas políticas y nuevas condiciones del crédito, siempre beneficiando al deudor, situación que algunos operadores judiciales no han querido entender, pues algunos de ellos previo a decretar la terminación del proceso le están solicitando a los bancos, o la reliquidación nuevamente, - confundiendo reliquidación con reestructuración -, o la reestructuración ya efectuada con el deudor como requisito para decretar la terminación de los mismos. 
Finalmente, en lo que respecta a que se pueden generar violaciones a derechos constitucionales, no es lógico que una sentencia de tutela ampare los derechos de unos cuantos y desproteja los derechos de otros, pues si la función de la Corte Constitucional es la protección de los derechos por igual ¿no sería que en este sentido se están violando también derechos constitucionales?, no sería que la Corte en su afán de proteger a los deudores, está pasando por encima de aquellos que no lo son?. Estos son simples interrogantes que quiero dejar planteado para que ustedes como lectores saquen sus propias conclusiones. 
Referencias Bibliográficas

Doctrina

Alfonso, G.; Kovner, A. \& Schoar, A. (2010). Stressed, Not Frozen: The Federal Funds Market in the Financial Crisis. Federal Reserve Bank of New York.

Alioto, Daniel Guillermo. (2.002) Contrato De Mutuo. Instituto de Estudios Filosóficos Santo Tomás de Aquino. Argentina

Arteaga, J. \& Arteaga, M. (1995). Curso de derecho civil: contratos. $1^{1}$ ed. Bogotá: Temis.

Arteaga, Jaime. (1.980) Curso de derecho civil y contratos. Capítulo VII. Editorial. Temis.

Arrubla, Jaime. (2009). Contratos Mercantiles. Contratos típicos. Tomo II. 12ava ed. Bogotá: Biblioteca Jurídica.

Azula Camacho, Jaime. (1.999) Manual de Derecho Procesal Civil. Tomo IV, 3ª ed. Colombia: Editorial Temis.

Becerra, Henry Alberto. (2010). Derecho Comercial de los Títulos Valores. 5 ${ }^{\underline{a}}$ ed. Bogotá, D.C., : Ediciones Doctrina y Ley Ltda.

Bercovitz, Rodrigo. (2009). Tratado de contratos. (Derecho español). Tomo IV. Bogotá: Editorial Tirant lo Ballianch.

Bernardos Dominguez, Gonzalo. (2006) ¿Puede bajar el precio de la vivienda en España? Expansión 24 de Octubre. 
Bernardos Dominguez, Gonzalo. (2007). ¿Cómo invertir con éxito en el mercado inmobiliario? La Coruña. Ed. Netbiblo.

Bernardos Dominguez, Gonzalo. (2008). Las entidades financieras cierran el grifo. Directivos Construcción. Número 209, Marzo.

Bernardos Dominguez, Gonzalo. (2008). Como salir de la crisis inmobiliaria. Directivos Construcción. Número 215, Octubre

Biondi, Biondo, (1.953). "La terminología romana como primera dogmática jurídica" en Arte y ciencia del derecho, Ediciones Ariel, Barcelona.

Blasco Gascó, F.P. (2000). La hipoteca inmobiliaria y el crédito hipotecario. Valencia: Triant Lo Blanch.

Bonivento Fernández, J.A. (1989). Los principales Contratos Civiles y su paralelo con los comerciales. $8^{\underline{a}}$ ed. Bogotá: Ediciones Librería del Profesional.

Bonivento, José Alejandro. (1.995) Los Principales Contratos Civiles. $10^{\underline{a}}$ ed. Colombia: Ediciones Librería del Profesional.

Bonivento, Alejandro. (2005). Los principales contratos civiles y su paralelo con los comerciales. 16ava ed. Bogotá: Ediciones del profesional Ltda.

Borda, Guillermo A., (2005). Tratado de derecho civil, contratos, $1^{\underline{a}}$ ed., Buenos Aires, Abeledo-Perrot.

Calvo Baca, Emilio. (1.998). Código de Comercio Venezolano. Comentado y Concordado. Venezuela. 
Cardona, Guillermo. (2001). Contratos civiles. $3^{\text {a }}$ ed. Bogotá: Ediciones doctrina y ley Ltda.

Carlson, J. \& Lindner, J. (2010). Recent Firming in the Federal Funds Market, Federal Reserve Bank of Cleveland, Economics Trends.

Case, K. (2.008) "The Central Role of House Prices in the Current Financial Crisis: How will the Market Clear?", ponencia presentada en Brookings Papers on Economic Activities, Washington, 11 de septiembre.

Cuadro, Lucía; Romo, Luna \& Rubio, Margarita. El mercado hipotecario residencial en Estados Unidos. En: Boletín Económico, Banco de España. Junio 2010

Cubides, Jorge Camacho. (1.999). Obligaciones. Bogotá: 4a ed. Pontificia Universidad Javeriana.

Delvasto P., Carlos Andrés. (2.008). Ensayo: El límite a la tasa de interés remuneratoria en el régimen comercial de Colombia: ¿Costo de transacción y barrera legal? Artículo de la revista criterio jurídico. Colombia.

Diez-Picazo, Luis. (1.986). Fundamentos del Derecho Civil Patrimonial Volumen I, España: Editorial Tecnos S.A.

Diez Picazo, Luis. (1.996). Fundamentos del Derecho Civil Patrimonial. $5^{\mathrm{a}}$ ed. Madrid: Editorial Civitas.

Farfán Mojica, C.E. (2002). Guía Práctica del crédito de vivienda en UVR. Bogotá, D.C.: Legis Editores.

Fernández Cruz, Gastón. (1991). La Naturaleza Jurídica de los Intereses: punto de conexión entre Derecho y Economía. En: Derecho, Revista de Derecho editada por el Fondo Editorial de la Pontificia Universidad Católica del Perú, № 45 . 
Fondo Monetario Internacional. (2008). Global Financial Stability Report. Washington D.C.

García, J. (2009). Nuevas y especiales formas de garantía en el comercio. Estudio sistemático y crítico. Madrid: Editorial. La Ley.

Garrido \& Zago. (1.998). Contratos Civiles y Comerciales. Tomo 2. $2^{\mathrm{a}}$ ed. Edita, Editorial universidad.

Gastaldi, Jose M \& Centenario, Esteban. (1.998). Contratos Aleatorios y Reales. Buenos Aires: Edita: fundación editorial Belgrano.

Ghersi, Carlos Alberto. (1995). Contratos civiles y comerciales. $2^{\underline{a}}$ ed. Madrid: Astrea, 1995.

Goldman, Sachs. Stocks dominate Flows: Only a Modest Rise in Mortgage Rates when Fed Purchases End, Informe diario. US Daily. (4 de marzo de 2010).

Gorton, G. (2.008). "The Subprime Panic", NBER Working Papers 14398, 2008.

Gracia, O., Echeverry, J.C. y Urdinola B.P. (1999). Upac: Evolución y crisis de un modelo de desarrollo. En: Archivos de Macroeconomía. No. 128. Bogotá, D.C.: Dirección de Estudios Económicos. Departamento Nacional de Planeación.

Green, R. \& Watcher, S. (2009). The Housing Finance Revolution. University of Pennsylvania Institute for Law \& Economics, Research paper no 0937.

Herrera Paulsen, Darío y otro. (1.999), "DERECHO ROMANO”, Editora: Gráfica Horizonte S.A., Lima - Perú. 
Iglesias, Juan. (2002), Derecho Romano, Edición catorce, Editorial Ariel, Barcelona España

Integrated Financial Engineering. (2006). Evolution of the housing Finance System: A Historical Survey and Leassons for Emering Mortgage Markets. Preparado para el US Dept. of Housing and urban Development.

Kindleberger, Ch. y R. Aliber. (2.005) Manias, Panics and Crashes: a History of Financial Crises, Hoboken, Wiley.

Lafont, Pedro. (2002). Manual de contratos, panorama de la negociación y contratación contemporánea. $2^{\underline{a}}$ ed. Bogotá: Ediciones del Profesional Ltda., 2002.

Lehman, Enneccerus. (1.944). Derecho de Obligaciones. Editorial Pérez González y Alguer Barcelona.

Lincoyan Portus, Govinden. (1.999) Cartilla de Matemáticas Financieras, 3a ed. México Editorial Mc Graw Hill, Unidad 1.

López Blanco, H.F. (2001). Ley de vivienda (546 de 1999) y sus implicaciones en el campo procesal civil. Bogotá, D.C.: Dupré Editores.

López Blanco, Hernán Fabio. (2.004). Instituciones de Derecho Procesal Civil Colombiano, 8va ed. Colombia: Editorial, Dupre Editores.

López de Zavalía, Fernando J. (2004), Teoría de los contratos, T. 5, Parte Especial (4), Buenos Aires. Ediciones Depalma 
Lorenezzetti, Ricardo Luis, (1.999). Tratado de los Contratos. Tomo 3. $7^{\text {a }}$ ed. Argentina: Editorial Rubinzal Culzoni.

Llambías, J. J., (2004). Tratado de derecho civil-Obligaciones, t. II-A, 2ª edición, Editorial Perrot, Buenos Aires

Madrid Parra, A. (1998). El mercado hipotecario (EE.UU. - España) Madrid: Banco Hipotecario de España.

Mansilla Piza, Emiliano. (2.010). Ensayo. El Contrato de Mutuo. Argentina

Marquez Miranda, Anibal. (1.963). El contrato y las relaciones jurídicas sometidas a la "Condictio lure". Buenos Aires: Edición Manes.

Marshall, W.D. (1983). Mortgage lending. Fundamentals \& Practices. Virginia: Reston Publishing Company.

Marti y De Eixala, Ramón. (1.838) Tratado elementar de derecho civil romano y español, España.

Martínez Coco, Elvira. (1.997). Ensayos de Derecho Civil I. Editorial San Marcos. 1aㅗ ed. Lima, Perú

Martínez N., Néstor Humberto. (2.003). Cátedra de Derecho Bancario Colombiano $2^{\underline{a}}$ ed. Bogotá: Legis.

Mazeaud, Henry., León y Jean. (1.959) 'Lecciones de Derecho Civil'. Tercera Parte. Vol. IV. Buenos Aires, Edita: Jurídicas Europa- América.

Merton, R. (1.968). Social Theory and Social Structure, New York, Free Press.

Messineo, Francesco. (1.952). Manual de Derecho Civil y Comercial. Tomo I. Buenos Aires. Edita: Ediciones Jurídicas Europa - Americana. 
Messineo, Francesco. (1.968). Doctrina General del Contrato, tomo I, Buenos Aires, Ediciones Jurídicas Europa-América.

Meza Barros, Ramón. (1.975). Manual de Derecho Civil, de las fuentes de las obligaciones, Tomo II, Editorial Jurídicas de Chile.

Monroy Cabra, Marco Gerardo. (2003). Introducción al Derecho, Décimo Tercera Edición, Editorial Temis S.A., Bogotá - Colombia.

Montealegre, L.E. (2006). Constitución y Vivienda. Bogotá, D.C.: Instituto de Estudios Constitucionales Carlos Restrepo Piedrahita.

Morales Casas, F. (2003). Fundamento de la actividad y los negocios bancarios. $3^{\text {a }}$ ed. Bogotá: Jurídica Radar Ediciones.

Morris, S. y H. S. Shin. (2.008). "Financial Regulation in a System Context", ponencia presentada en Brookings Papers on Economic Activities, Washington, 11 de septiembre.

Muñoz, O'Callaghan (2004). Compendio de Derecho Civil. Tomo 3 (Derechos reales e hipotecario) Madrid: Edita Edersa.

Muñoz, Luis. (1.960). Derecho Comercial, Contratos. Tomo 3. Argentina: Edita, tipografía editora Argentina.

Narváez García, José Ignacio. (2.002). Derecho Mercantil Colombiano, Volumen I, Parte General. 9a ed., Colombia: Editorial Legis.

Noguera, Enrique. (2009). De los contratos principales y nociones civiles $y$ comerciales. $1^{\underline{a}}$ ed. Bogotá: Universidad Sergio Arboleda. 
Ocde, (2005). Recent House Developments: The Role of fundamentals. Economic outloock. Número 78, Diciembre.

Ospina Fernández, Guillermo. (1.994)Teoría General del contrato de los demás actos o negocios jurídicos. Bogotá: Editorial Temis.

Ospina Fernández, Guillermo. (2.001). Régimen General de las Obligaciones, $7^{\mathrm{a}}$ ed. Colombia: Editorial Temis.

Ospina Fernández, Guillermo (2.005). Teoría General del Contrato y del Negocio Jurídico. Edita, Temis, $7^{\text {a }}$ ed.

Peña, Lisandro. (1999). Contratos Mercantiles nacionales e internacionales. $3^{a}$ ed. Bogotá: Temis.

Pérez Salazar, Mauricio. (2.008). Revista de Economía Institucional. Vol. 10 \# 19 El Origen del Pánico de 2.008: La Crisis en el Mercado Hipotecario en los Estados Unidos. Bogotá

Petit, Eugene. (1.971). Tratado elemental de derecho romano, México, Editora Nacional.

Robledo Uribe, Emilio. (1.959) Instrumentos negociables. Colombia: Lucros Ediciones.

Robles de Arévalo, Carmen del Pilar. (1.999). Régimen Legal de los Intereses para Adeudos de Carácter Civil y Financiero. Separata-resumen para el dictado de clase en el curso de Obligaciones de la Pontificia Universidad Católica del Perú. Lima junio de 1.999

Rodríguez Azuero, Sergio. (2.000). Contratos bancarios: Su significación en América Latina. $5^{a}$ ed. Bogotá: Legis.

Rodríguez Azuero, S. (2002). Contratos bancarios, su significación en América Latina. 5aㅡ. ed. Bogotá: Legis. 
Rodriguez, Velarde Javier. (2.002). Contratos e Instrumentos Bancarios, Doctrina, modelos y legislación bancaria, 2ª ed. Lima (Perú): Editorial Rodhas.

Rojas, Liliana. (2008). El Mercado Hipotecario Americano: El origen de la crisis. En: Revista Portafolio.co. (diciembre 18 de 2009); p.1-4

Rojas González, Germán. (2.001). Manual de Derecho Civil.

Rojina Villegas, Rafael. (1.985). Derecho Civil Mexicano. 5 ed. México. Porrúa.

Saldaña Pérez, Jesús. (2.004). Compendio de términos de derecho civil. Instituto de investigaciones jurídicas, México.

Sánchez, María (1992). Contratos bancarios. 1르 ed. Madrid: Editorial Madrid 1992.

Sánchez, R. \& De Valdivia, I. (1996). La hipoteca y los bienes inmuebles por destino. Madrid: McGraw Hill.

Sarabia Rupérez, Bruno (2008). Artículo Escrito: La crisis hipotecaria Española. Revista Tribuna.

Shiller, R. (2009). El estallido de la Burbuja. Barcelona, ed. Gestión 2000

Schwartz, Herman. Boom to bust housing, politics and financial crisis in America. Subprime Nation, Cap. 7.

Treviño García, Ricardo (1.994). Epítome de los contratos, México, McGraw-Hill. Treviño García, Ricardo, (1.995). Los contratos civiles y sus generalidades, 5ae ed., México, McGraw-Hill. 
Tola Cires, Fernando, (1.997). "DERECHO ROMANO" Obligaciones, Contratos, Delitos y Acciones 3ํㅡㄹ Ed. Perú: Editorial San Marcos, Lima - Perú

Valencia Zea, Arturo. (1.986). Derecho Civil, Tomo III de las Obligaciones. $7^{\mathrm{a}}$ ed. Colombia: Editorial Temis.

Valencia Zea, Arturo. (1.998). Derecho civil, Los contratos, Tomo IV Edita. Temis, Colombia.

Vásquez Olivera, Salvador. (2.002). Derecho Civil Definiciones. Palestra Editores, Lima, Perú.

Villegas, Carlos Gilberto y Schujman, Mario. (1.990). Intereses y tasas. Buenos Aires, Abeledo Perrot.

Von Thur Andreas. (1.934) Tratado de las obligaciones, Madrid. Tomo I.

Zavala Rodríguez, Carlos Juan, (1969) Código de Comercio y leyes complementarias, III, Ediciones Depalma Buenos Aires, 1969, p. 7; C.N. Civ.

Diccionario de la lengua española. (2.001) Real Academia Española . 12ª edición.

Diccionario jurídico Mexicano.12ª Ed. México. Porrúa y Unam 1.998.

Diccionario Para Contadores Eric L. Kohler, Editorial Limusa

Concepto Superintendencia Bancaria de Colombia. 1999015883-2 del 4 de mayo de 1999.

Jurisprudencia

Consejo de Estado. Sentencias:

1476 de 2001. C.P. Gabriel Eduardo Mendoza Martelo. 
12 de Diciembre de 2002 C.P. Mario Alirio Mendez.

21 de mayo de 1999 C.P. Daniel Manrique Guzmán.

Corte Constitucional. Sentencias:

C - 700 de 1999. M.P. José Gregorio Hernández.

C - 955 de 2000. M.P. José Gregorio Hernandez.

T - 511 de 2001. M.P. Eduardo Montealegre Lynett.

T - 606 de 2003. M.P. Álvaro Tafur Gálvis.

T - 701 de 2004. M.P. Rodrigo Uprimny Yepes.

T- 258 de 2005. M.P. Jaime Araujo Rentería.

T -- 282 de 2005. M.P. Rodrigo Escobar Gil.

T - 896 de 2005. M.P. Jaime Córdoba Triviño.

T - 144 de 2006. M.P. Jaime Córdoba Triviño.

SU - 813 de 2007. M.P. Jaime Araújo Rentaría.

C-383 de 1999 M.P. Alfredo Beltrán sierra.

Expediente T 1180244 Octubre 20 de 2005 M.P. Alfredo Beltrán

Sierra.

Corte Suprema de Justicia, Sala Civil. Sentencias:

Enero 20 de 2005. M.P. Edgardo Villamil Portilla.

Septiembre 3 de 2002. M.P. Jorge Santos Ballesteros. Exp. No 680012203000200200094-01.

Septiembre 29 de 2004. M. P. Manuel Isidro Ardila Velásquez Exp. No 110010203000200401033.

Sentencia de Tutela de Septiembre 30 de 2002.

Expediente 00413 M.P.

Tribunal Superior del Distrito Judicial de Bogotá D.C., Sala Civil. Sentencias:

Marzo 7 de 2005. M.P. Luz Magdalena Mojica.

Mayo de 2005. M.P. Ricardo Sopó Méndez.

Mayo 27 de 2005. M.P. José Alfonso Isaza Dávila. 
Agosto 12 de 2005. M.P. Edgar Carlos Sánchez Melo.

Agosto 18 de 2005. M.P. Ruth Marina Díaz Rueda.

Febrero 16 de 2006. M.P. Ruth Marina Díaz Rueda.

Noviembre 21 de 2005. M.P. Liana Aída Lizarazo

Marzo 20 de 2007. M.P. José Elio Fonseca Melo

Tribunal Superior del Distrito Judicial de Cundinamarca, Sala Civil - Familia - Agraria. Sentencias:

Abril 26 de 2006. M.P. Luís Ernesto Vargas Silva.

Tribunal Superior del Distrito Judicial de Medellín, Sala Civil. Sentencias:

Mayo 31 de 2001. M.P. Jaime Arturo Gómez Marín

\section{Legislación}

Constitución Política de Colombia.

Código Civil Colombiano.

Código de Comercio Colombiano.

Código de Procedimiento Civil Colombiano.

Código Civil para el Distrito Federal de México.

Código Civil Venezolano.

Código Civil Francés.

Código Civil Argentino.

Código Civil Español.

Ley 31 de 1992 Diario oficial, 4 de Enero de 1.993. CONGRESO DE LA REPUBLICA.

Ley 546 de 1999 Diario oficial No 43.827 del 23 de Diciembre de 1.999. CONGRESO DE LA REPUBLICA.

Decreto 2331 de 1998 Diario Oficial No 43.430 del 16 de Noviembre de 1.998. MINISTERIO DE HACIENDA Y CREDITO PUBLICO.

Decreto 677 de 1972, Registro distrital 226 de octubre 5 de 1.972. ALCALDIA MAYOR DE BOGOTA. 
Decreto 678 de 1972, Diario oficial No 33.594 del 18 de mayo de 1.972. PRESIDENCIA DE LA REPUBLICA.

Decreto 1229 de 1972 Diario Oficial No 33.663 del 16 de Agosto de 1.972. PRESIDENCIA DE LA REPUBLICA.

Decreto 1110 de 1976, Diario Oficial No 34.579 del 28 de Junio de 1.976. PRESIDENCIA DE LA REPUBLICA.

Decreto 2703 de 1999, Diario Oficial No 43.839 del 1 de Enero de 2.000 . MINISTERIO DE HACIENDA Y CREDITO PUBLICO.

Decreto 856 de 1999, Diario Oficial No 43.583 del 20 de mayo de 1.999. MINISTERIO DE HACIENDA Y CREDITO PUBLICO.

Resolución Externa No 6 de Marzo 15 de 1993, JUNTA DIRECTIVA DEL BANCO DE LA REPUBLICA

Resolución Externa No 26 de septiembre 29 de 1994. JUNTA DIRECTIVA DEL BANCO DE LA REPUBLICA.

Circular Externa No 18 de septiembre 13 de 1995. MINISTERIO DE HACIENDA Y CREDITO PUBLICO.

Circular Externa No 2 del 8 de Marzo de 2001. REPUBLICA DE COLOMBIA. SUPERINTENDENCIA DE VALORES.

Circular Externa No 85 del 29 de Diciembre 2.000. SUPERINTENDENCIA BANCARIA DE COLOMBIA

Circular Externa No 7 de septiembre 7 de 1.996. CIRCULAR BASICA JURIDICA.

Resolución 14 de septiembre 3 del año 2000. JUNTA DIRECTIVA DEL BANCO DE LA REPUBLICA.

Resolución 20 del 22 de diciembre del año 2000

Resolución 3 de mayo 20 de 2005. JUNTA DIRECTIVA DEL BANCO DE LA REPUBLICA

Recursos Digitales.

SECRETARIASENADO. Ley 546 de 1999. Recuperada el 30 de junio de 2009. Disponible en: http://www.secretariasenado.gov.co/senado/basedoc/ley/ 1999/ley_ 
0546_1999.html.

Pizarra legal. (2009). Recuperada el 25 de septiembre de 2010. Disponible en: http://pizarralegal.cuervoblanco.com.arg/?q=node/56.

http://www.nytimes.com/2008/10/03/business/03sec.html. 